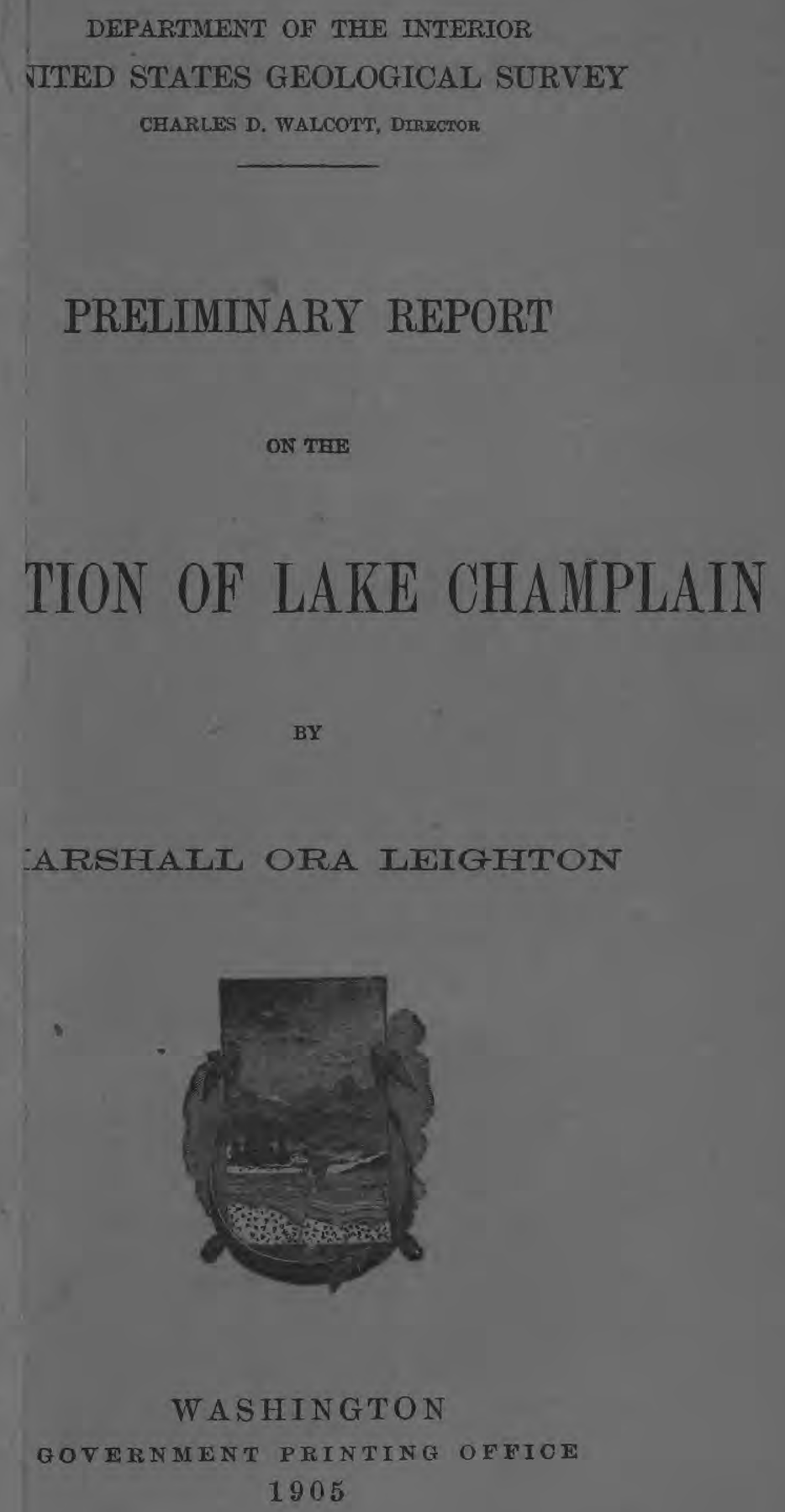

\section{PRELIMINARY REPORT}

\section{TION OF LAKE CHAMPLAIN}

BY

\section{ARSHALL ORA IEIGHTON}

,

WASHINGTON

GOVERNMENT PRINTING OFEICE

1905 
DEPARTMENT OF THE INTERIOR

UNITED STATES GEOLOGICAL SURVEY

CHARLES D. WALCOTT, DIRECTOR

\section{PRELIMINARY REPQRT Resources Branch, Geological Survey, on the Box 3106, Capitol Station Oklahoma City, Okla.}

\section{POLLUTION OF LAKE CHAMPLAIN}

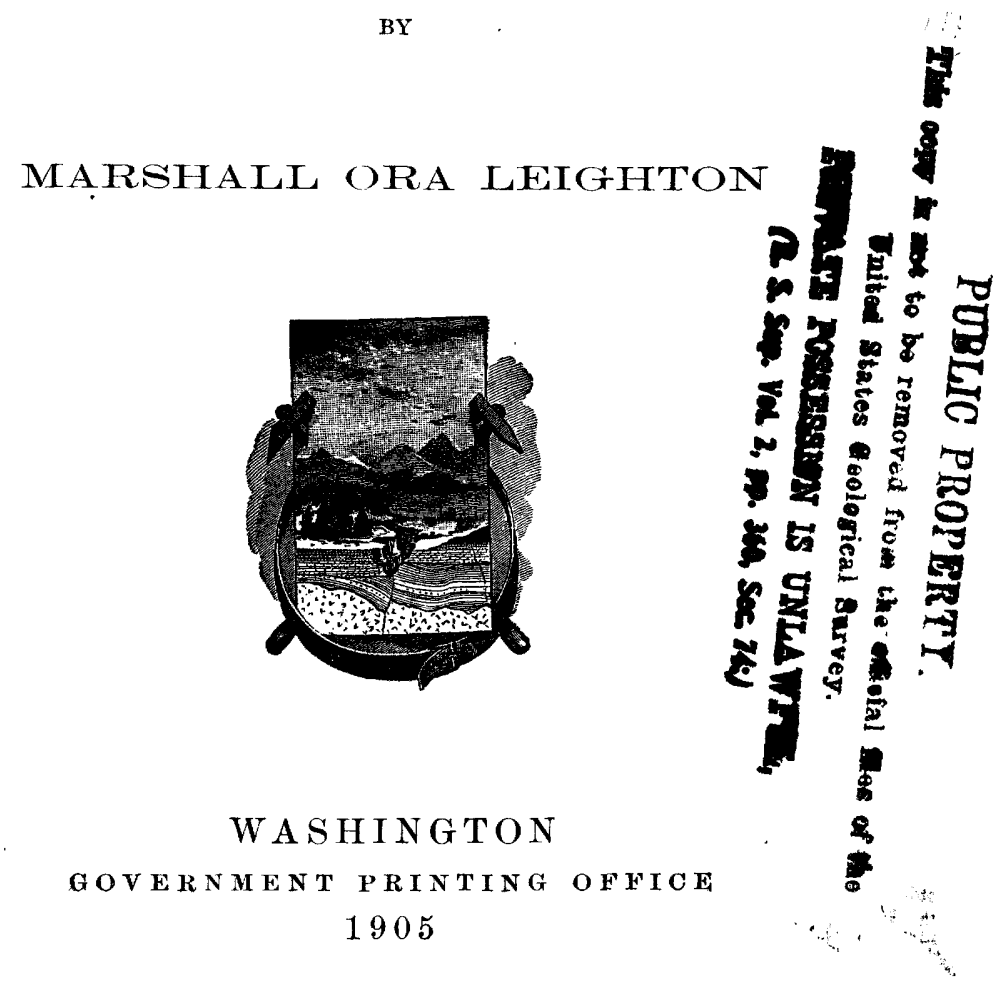




\section{CONTENTS.}

Page.

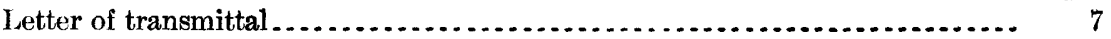

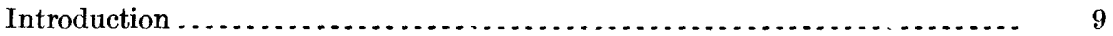

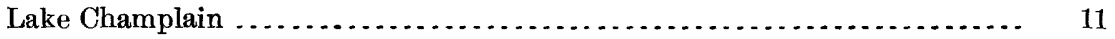

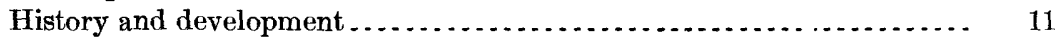

General description........................................ 14

Characteristics of water .................................... 20

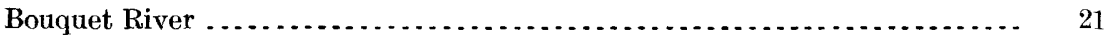

Origin, course, and flow ........................................ 21

Soda-pulp pollution........................................ 23

Constituents of the pulp................................... 23

Manufacture of the pulp ................................ 24

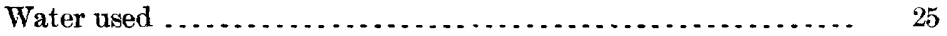

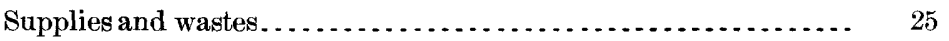

First liquid effluent .................................. 25

Recovery of soda................................. 28

Second, third, and fourth liquid effluents .................. 29

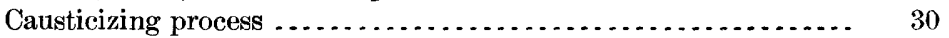

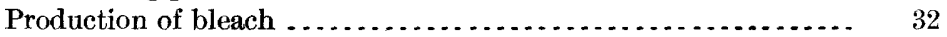

Disposal of sludge .......................................... 33

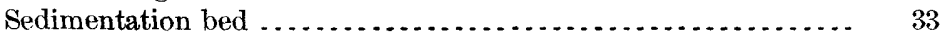

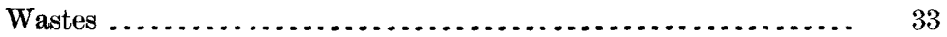

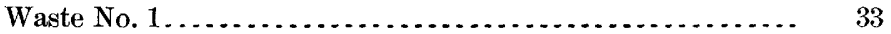

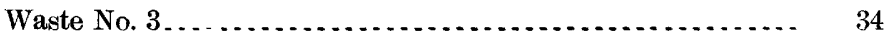

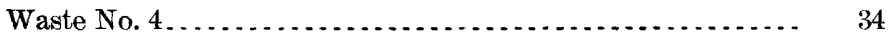

Efficiency of sedimentation bed........................... 35

Sedimentation-bed effluent............................ 36

Effects of soda-pulp waste................................ 36

Effect on Bouquet River ................................. 36

Character and extent ............................... 36

Conclusions ........................................ 38

Effect on Lake Champlain ............................. $\quad 39$

Methods of investigation .......................... 39

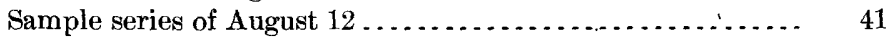

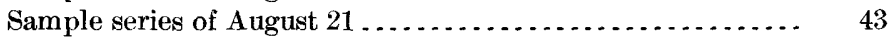

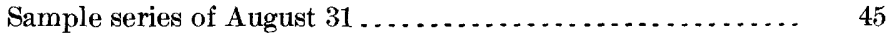

Conclusions .................................. 47

Ansable River................................................ 48

Origin and course................................................ 48

Sulphite-pulp pollution ..................................... 49

Manufacture of the pulp . . . . . .

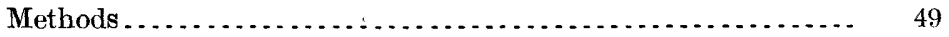

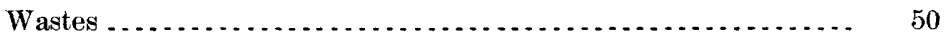

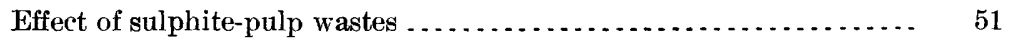

Effect on Ausable River................................ 51 
Ausable River-Continued.

Sulphite-pulp pollution-Continued.

Effect of sulphite-pulp wastes-Continued.

Effect on Lake Champlain ................................ 53

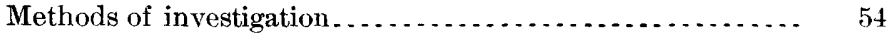

Sample series of August 23...................... 54

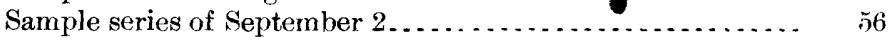

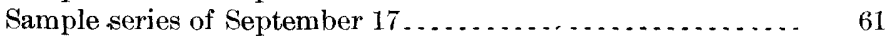

Conclusions ....................................... 62

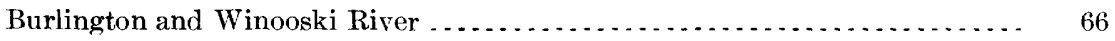

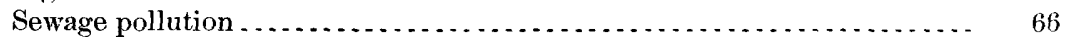

Sources of sewage and places of discharge $\ldots \ldots \ldots \ldots \ldots \ldots \ldots .66$

Effect on Lake Champlain .................................. 67

Earlier investigations ..................................... 68

Present conditions.............................................. 74

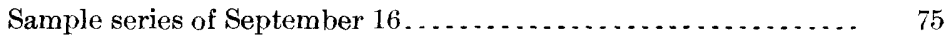

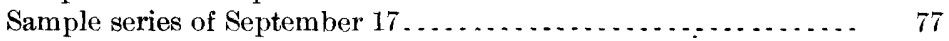

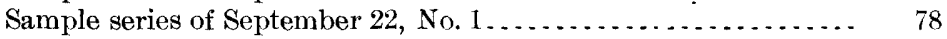

Sample series of September 22, Nos. 2 and $3 \ldots \ldots \ldots \ldots \ldots . .83$

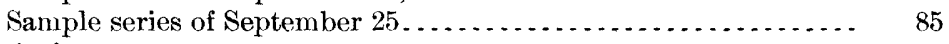

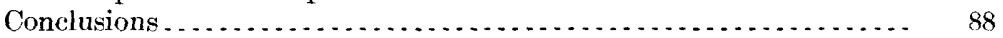

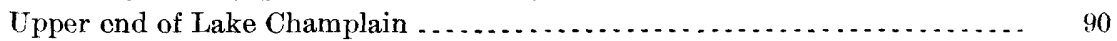

Soda-mill and sewage pollution................................. 90

Character of upper-lake water ............................. 91

Character of Ticonderoga Creek water above pulp mill ............ 93

Ticonderoga Pulp and Paper Company ....................... 94

Manufacture of the pulp .............................. 95

Sedimentation bed ....................................... 96

Effect of mill wastes . . . . . . . . . .

Effect on Ticonderoga Creek . . . . . . . . . . . . . . . . . . . . 97

Comparison of creek waters above and below mill ......... 98

Comparison of creek and lake waters................. 99

Effect on Lake Champlain .............................. 102

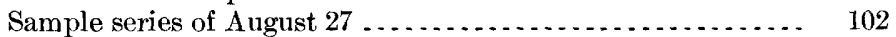

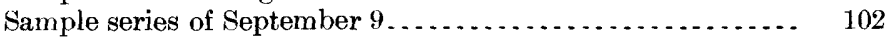

Conclusions ............................................... 107

General conditions in Lake Champlain.......................... 108

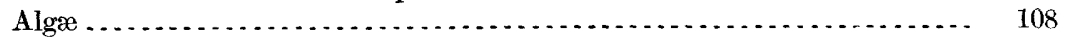

General conditions of existence........................... 109

Algæ in Lake Champlain................................. 110

Effect of mill waste on algæ ............................... 110

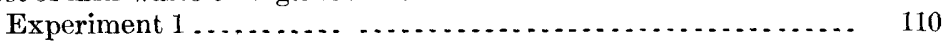

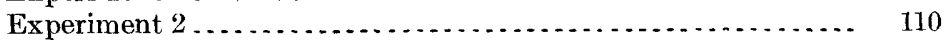

Bacteria ................................................ 111

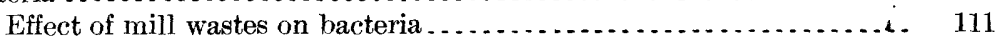

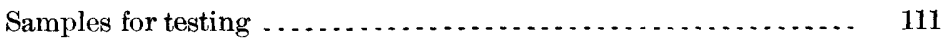

Report of Mr. Earl B. Phelps........................... 111

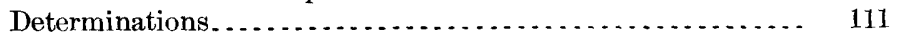

Effect of wastes on mosquitoes...................... 111

Germicidal effect of wastes on sewage bacteria ........... 112

Effect of wastes on specific disease germs . . . . . . . . . . . 113

Conclusions ...................................... 114

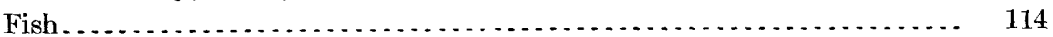

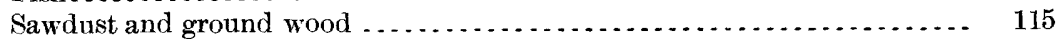

Summary ......................................................... 115

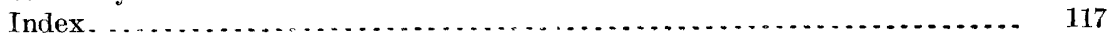




\section{L L U S T R A T I 0 N S .}

Plate I. Map of Lake Champlain and vicinity -......

II. $A$, Ruins of Crown Point Fortress; $B$, Waste trough crossing Bouquet River at Willsboro mill ................................ 18

III. $A$, Bouquet River above Willsboro; $B$, Falls in Bouquet River at Willsboro .......................................... 22

IV. $A$, Soda-pulp mill at Willsboro; $B$, Ausable Chasm ............ 24

$\checkmark$. $A$, Effluent weir from Willsboro sedimentation bed; $B$, Falls at head of Ausable Chasm ................................. 32

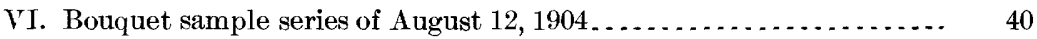

VII. Bouquet sample series of August 21, 1904.................. 42

VIII. Bouquet sample series of August 31, 1904.................. 46

IX. $A$, Wood pulp and sawdust on west shore of Lake Champlain; $B$, Falls on Ausable River at Keeseville, N. Y .................. 48

X. $A$, Burlington, Vt., lake front; $B$, Trunk sewer outlet, Burlington, Vt. $\quad 66$

XI. $A$, Water power of Ticonderoga Pulp and Paper Company, Ticonderoga, N. Y.; $B$, View at Ticonderoga, N. Y ................

XII. Water power of International Pulp Company, Ticondernga Creek: $A$, "A" mill; $B$, "B" mill . . . . . . . . . . . . . . . . . . . . . . . . . . . . . 92

XIII. $A$, Sedimentation bed of Ticonderoga Pulp and Paper Company; $B$, Mills of Ticonderoga Pulp and Paper Company ...............

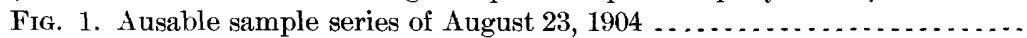

2. Ausable sample series of September $2,1904 \ldots \ldots \ldots \ldots \ldots \ldots \ldots \ldots$.

3. Ausable sample series of September 17, 1904 ..................

4. Burlington sample series of September 16 and $17,1904 \ldots \ldots \ldots \ldots . .77$

5. Burlington sample series of September 22, 1904, No. 1 ............ 79

6. Burlington sample series of September 22, 1904, Nos. 2 and 3 ....... 84

7. Burlingtom and Winooski sample series of September 25, 1904 ....... 87

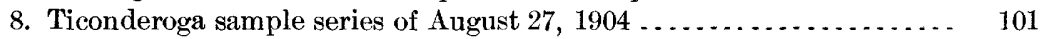

9. Ticonderoga sample series of September $9,1904 \ldots \ldots \ldots \ldots \ldots \ldots . . . \ldots 5$ 


\section{LETTER OF TRANSMITTAL.}

\section{DePartMent OF THE InTERIOR, \\ United States Geological Survey, Hydrographic Branch, Washington, D. C., December 12, 1904.}

SrR: I have the honor to transmit herewith a manuscript entitled "Preliminary Report on the Pollution of Lake Champlain," by Marshall Ora Leighton, and to request that it be published as one of the series of Water-Supply and Irrigation Papers.

Lake Champlain is an interstate and international body of water. In colonial times it was of great commercial importance, and with the development of the national resources in its immediate drainage area it became a great highway. Its greatest industrial importance was during the period 1860 to 1890 , since which time, by reason of railroad competition and the closing of many industries, its commercial position has steadily declined. At present it appears that its future usefulness will be that of a source of water supply, and therefore the character of the lake water is of first importance.

The investigations reported in this paper were made in response to a request of Hon. John G. McCullough, governor of the State of Vermont. A remarkably persistent agitation had been going on concerning the pollution of the lake by certain cities and industrial plants, and allegations were made which involved the States of New York and Vermont, with all the consequent interstate and international questions. The time at the disposal of the author was too short to complete an extended investigation of the whole question, and therefore the work was confined to a consideration of the specific points at issue. The investigations reported are of great value outside of the immediate area tributary to Lake Champlain, for the subject of pollution of natural waters by industrial wastes is of prime importance in every manufacturing region.

Very respectfully,

F. H. Newell, Chief Engineer.

Hon. Charles D. Walcott, Director United States Geological Survey. 


\title{
PRELIMINARY REPORT ON THE POLLUTION OF LAKE CHAMPLAIN.
}

\author{
By M. O. Leighton.
}

\section{INTRODUCTION.}

Certain persons owning property along the shores of Lake Champlain allege that the water of the lake is being polluted by enormous discharges of waste materials from the several wood-pulp mills located upon the tributary streams in New York State. They also claim that sewage from the various cities situated on the lake border, especially from Burlington, Vt., is a damage to the water, though to a far less degree than that from the pulp mills. The allegations of these parties to the controversy may be briefly summed up as follows:

1. That the water of the lake has been rendered unfit for domestic cousumption.

2. That the discharges from the mills are destructive to fish life and that dead fish are washed upon the shores in ruinous quantities.

3. That the taste of the water is so disagreeable that cattle refuse to drink it and the usefulness of the lake as a watering place for stock is thereby destroyed.

4. That the wastes from the mills promote a luxuriant growth of green algæ, which, gathering along the shores, make them unattractive and decrease the value of property for summer homes.

5. That the proprietors of the pulp mills wantonly discharge these wastes into the lake, making no worthy efforts to improve the condition, but rather postponing by equivocation, false promises, and legal subterfuges the day of rightful adjustment.

In response to these allegations the proprietors of the various mills state that the wastes discharged into the lake are in nowise harmful thereto, that they are taking all possible precautions against and have spent large sums of money to prevent the pollution of the lake, and that the parties to the complaint are misinformed, unduly alarmed, or wantonly untruthful.

The city of Burlington, Vt., the largest community upon the lake, draws its water supply therefrom and discharges its sewage at a point less than 3 miles from the water intake. In this city there appears to be little apprehension concerning the influence of the city sewage upon 
the water supply, but great alarm has been felt lest the wastes from the pulp mills on the New York side of the lake should flow across the normal lake current for 10 miles and poison the city supply.

The conditions outlined above led at first to a mild and considerate discussion among the parties interested, which finally developed into an acrimonious struggle, full of personal bitterness and involving in the end both the New York and the Vermont State governments. Through the press the conditions were widely advertised and much distorted. The situation became so acute that a thorough investigation was deemed necessary, and the following communication was addressed to the Director of the United States Geological Survey by the Hon. John G. McCullough, Governor of the State of Vermont:

North Bennington, VT., March 31, 1904.

StR: An extended examination of the waters of Lake Champlain with especial reference to the effect of polluting materials turned into the lake would be extremely desirable and of public benefit at the present time.

Lake Champlain is, as you are aware, an interstate body of water and its resources are of great importance to the States of Vermont and New York. In order that these resources may be conserved it is necessary that the purity of its waters be maintained. Therefore a determination of the present condition of the lake, the effect of the wastes which are being poured into it, and the conditions which are likely to arise in the future if present practices with reference to waste disposal are continued is highly desirable.

On account of the interstate features which prevail, I am of the opinion that the work above outlined can better be carried on by some national authority, and as I am informed that the hydrographic branch of the United States Geological Survey is empowered by Congress to determine the water supplies of the United States and an appropriation is made therefor, I respectfully request that an equitable portion of the funds available for such work be applied to the investigation of Lake Champlain and that properly qualified officials be assigned to the work.

Respectfully, yours,

The Director

John G. McCullovgh, Governor.

U. S. Geological Survey, Washington, D. C.

In compliance with the above request the author of this report was detailed to carry on the investigations, and entered upon the work July 1, 1903. He desires here to make acknowledgment of timely services rendered during the investigation by many persons, and especially by Mr. Edward Hatch, jr., and Mr. A. H. Ellis, the principal parties to the original complaints; Mr. A. G. Paine, jr., general manager of the New York and Pennsylvania Company; Mr. R. L. P. Mason, superintendent of the Champlain Mills of the New York and Pennsylvania Company; Mr. Charles E. Bush, general manager of the Ticonderoga Pulp and Paper Company; Mr. James Rogers, of the J. and J. Rogers Company; Dr. B. H. Stone and Mr. C. P. Moat, of the State laboratory of hygiene, Burlington, Vt.; Hon. Edward L. Bates, secretary of civil and military affairs, State of Vermont; and, finally, to His Excellency, Governor John G. McCullough, State of Vermont. 


\section{LAKE CHAMPLAIN.}

\section{HISTORY AND DEVELOPMENT.}

Samuel de Champlain, a native of Brouage, a Catholic supporter of Henry of Navarre, sometime in the service of Spain in the Caribbean, and finally a governor of New France, discovered Lake Champlain on July 4, 1609. The purposes of his journey from the new settlement at Quebec to this body of water were not those of exploration and discovery, nor was be actuated by the spirit of legitimate conquest as it was then recognized. His first visit to the lake was in confirmation of an agreement with the Algonquian Nation to intervene in the struggle between it and the Iroquois. The discovery of Lake Champlain was but an incident in an ill-advised campaign which in after years brought untold suffering and death to French colonists-a campaign which has never been justified, rarely defended, and which in the final analysis seems to have been merely the indiscreet act of a brave and distinguished warrior impatient of his idle sword.

The discovery of Lake Champlain and the discoverer's espousal of the Algonquian cause is all important in the subsequent history of the lake. The country thereabout became a battle ground on which was fought out the relentless hatred of the Iroquois for the French. "It was but a holiday skirmish for the French, but it was the cause of a bitter and bloody hatred on the part of the Iroquois, a hatred which afterwards never slept. The long-standing enmity cherished by that nation toward the Algonquins extended thenceforth to the French also. In later years, when the English and Dutch sided with the Iroquois, the feud became a fierce and deadly war that at times threatened the life of the whole colony of New France."

So it was that Lake Champlain afterwards became a route by which the northern and southern Indian nations made their attacks upon each other. It was hotly contested country during all the colonial wars between the French and the English, and after the British dominion included Canada it was again a great warpath during the war of the Revolution and that of 1812 . During all these years the country grew in commercial and political importance, and the lake was a great highway in times of peace. With the opening of Champlain Canal, connecting the southern end of the lake with Hudson River, there came days of prosperity. Iron mines were opened in the Adirondack Mountains, the products of which found a ready outlet by way of the lake. The lumber interests were enormous, and many small ports grew up as centers for these products. The lake was a busy and bustling place, dotted over with lines of canal boats, rafts of logs, and vessels under sail and steam. 
All this has now practically disappeared. The visitor to the lake to-day will see at rare intervals a solitary line of canal boats under convoy of a steam towboat, a passenger steamer, of which there are several, making landings at important points, or the private boat of some well-to-do sojourner; oftener he will see nothing but a large expanse of water backed by blue mountains and intercepted here and there by groups of islands. This diminution of freight traffic seems to the observer even greater than the actual figures (Table II, p. 13) prove it to be. The freight is largely carried in canal boats, which are drawn together in a double line consisting usually of 30 to 40 individual boats. Thus a heavy tonnage is carried without giving to the lake the animated appearance which would result if the same burden were carried by many smaller boats. Viewed from many directions the lake is almost as solitary now as it must have been on the day of its discovery. It is a deep, long, narrow sea, beautiful in its details, whimsical in its changes, and treacherous in its storms. The cities and towns upon its banks have in many cases maintained their prosperity, though not by virtue of their position with reference to the lake. Many others have lapsed into rural distributing centers, interesting only in their memories.

The following table shows clearly the rise and fall of communities in the Lake Champlain region:

TABLE I.-Population of towns bordering on Lake Champlain.

\begin{tabular}{|c|c|c|c|c|c|c|c|c|c|}
\hline & 1820. & 1830. & 1840. & 1850. & 1860. & 1870. & 1880. & 1890. & 1900. \\
\hline Champlain, N. Y . & 1,618 & 2,456 & 3,632 & 5,067 & 5,857 & 5,080 & 5,407 & 5,207 & 4,748 \\
\hline Chazy, N. Y ..... & 2,313 & 3,097 & 3,584 & 4,324 & 3,399 & 3,206 & 3,147 & 2,867 & 2,796 \\
\hline Plattsburg, N. Y.......... & 3,519 & 4,913 & 6,416 & 5,618 & 6,670 & 8,414 & 8,283 & 9,500 & 11,612 \\
\hline $\begin{array}{l}\text { Chesterfield, N. Y. (includ- } \\
\text { ing Keeseville)........... }\end{array}$ & 667 & 1,671 & 2,716 & 4,171 & 3,179 & 2,795 & 2,752 & 2,548 & 2,362 \\
\hline Willsboro, N. Y............ & 888 & 1,316 & 1,658 & 1,932 & 1,519 & 1,719 & 1,450 & 1,568 & 1,522 \\
\hline Essex, N. Y........... & 1,225 & 1,543 & 1,681 & 2,351 & 1,633 & 1,600 & 1,462 & 1,437 & 1,333 \\
\hline Westport, N. Y ....... & 1,095 & 1,513 & 1,932 & 2,352 & 1.981 & 1,577 & 1,737 & 1,864 & 1,727 \\
\hline Moriah, N. Y ... & 842 & 1,742 & 2,595 & 3,065 & 3,466 & 4,683 & 7,379 & 6,787 & 4,447 \\
\hline Crown Point, $\mathrm{N} . \mathrm{Y}$ & 1,522 & 2,041 & 2,212 & 2,378 & 2,252 & 2,449 & 4,287 & 3,135 & 2,112 \\
\hline Ticonderoga, N. Y... & 1,493 & 1,996 & 2,169 & 2,590 & 2,271 & 2,669 & 3,304 & 3,980 & 5,048 \\
\hline Whitehall, N. Y ...... & 2,341 & 2,888 & 3,813 & 4,726 & 4,862 & 5,564 & 5,347 & 5,402 & 5,295 \\
\hline West Haven, Vt....... & & 724 & 774 & 718 & 580 & 713 & 492 & 412 & 355 \\
\hline Benson, vt ...... & & 1,493 & 1,403 & 1,305 & 1,256 & 1,244 & 1,104 & 880 & 844 \\
\hline Orwcll, Vt...... & & 1,598 & 1,504 & 1,470 & 1,341 & 1,192 & 1,351 & 1,265 & 1,150 \\
\hline Vergennes, Vt.. & & 999 & 1,017 & 1,578 & 1,286 & 1,570 & 1,782 & 1,773 & 1,753 \\
\hline Burlington, vt ... & & 3,526 & 4,271 & 7,521 & 7,713 & 14,387 & 11,365 & 14,590 & 18,640 \\
\hline St. Albans, vt ............. & $\ldots$. & 2,395 & 2,702 & 1,814 & 3,637 & 7,014 & 7,193 & 7,771 & 7,954 \\
\hline
\end{tabular}


TABLE II.-Freight traffic on Lake Champlain since 1839.

[Tons.]

\begin{tabular}{|c|c|c|c|c|c|}
\hline Year. & Entered. & Cleared. & Year. & Entered. & Cleared. \\
\hline $1833 \ldots$ & 67,477 & 67,101 & 1870 & 337,040 & 336,565 \\
\hline 1837. & 50,011 & 50,011 & 1871 & 325,668 & 318,675 \\
\hline $1838 \ldots$ & 62,008 & 62,008 & 1872. & 327,529 & 329,182 \\
\hline $1840 \ldots$ & 109,516 & 109,516 & $1873 .$. & 350,202 & 354,937 \\
\hline $1843 \ldots$ & 52,453 & 52,274 & 1874. & 273,619 & 274,962 \\
\hline $1844 \ldots$ & 107,386 & 108,182 & 1875. & 212,133 & 204,800 \\
\hline $1845 .$. & 89,801 & 89,073 & $1876 .$. & 192,856 & 192,629 \\
\hline $1846 \ldots$ & 104,571 & 108,212 & 1878. & 174,875 & 169,665 \\
\hline 1848. & 175,522 & 170,196 & 1879. & 179,324 & 186,227 \\
\hline 1849. & 193,988 & 192,536 & 1880. & 203,103 & 203,856 \\
\hline $1850 \ldots$ & 207,392 & 190,813 & 1881. & 213,407 & 219,506 \\
\hline $1851 \ldots$ & 217,855 & 212,648 & 1882. & 248,508 & 249,939 \\
\hline $1852 \ldots$ & 78,353 & 80,117 & 1883. & 249,949 & 156,424 \\
\hline $1853 .$. & 52,399 & 52,904 & 1884. & 223,260 & 212,429 \\
\hline $1854 \ldots$ & 102,469 & 97,678 & 1885. & 180,504 & 172,691 \\
\hline $1855 \ldots$ & 43,441 & 44,671 & 1886. & 178,493 & 175,782 \\
\hline $1856 .$. & 99,226 & 94,161 & 1887. & 182,326 & 177,754 \\
\hline $1857 \ldots$ & 122,543 & 117,336 & 1888. & 214,063 & 222,244 \\
\hline 1858. & 128,355 & 118,226 & 1889. & 209,459 & 215,790 \\
\hline 1859. & 101,614 & 96,845 & 1890. & 208,185 & 194,862 \\
\hline $1860 \ldots$ & 69,822 & 60,614 & 1891. & 150,366 & 157,350 \\
\hline $1861 \ldots$ & 94,132 & 67,203 & 1892. & 137,850 & 132,626 \\
\hline $1862 \ldots$ & 68,426 & 56,311 & 1893. & 151,189 & 145,324 \\
\hline 1863. & 103,886 & 147,652 & 1894. & 144,849 & 149,731 \\
\hline $1864 \ldots$ & 165,330 & 155,474 & 1895. & 163,238 & 156,840 \\
\hline 1865. & 175,813 & 172,471 & 1896. & 201,070 & 224,033 \\
\hline $1866 \ldots$ & 187,050 & 179,365 & 1897. & 182,054 & 181,499 \\
\hline $1867 \ldots$ & 200,623 & 188,404 & 1898. & 179,714 & 180,710 \\
\hline $1868 \ldots$ & 219,530 & 201,357 & 1899 & 113,130 & 111,446 \\
\hline $1869 \ldots$ & 294,767 & 278,431 & 1900. & 146,613 & 156,393 \\
\hline
\end{tabular}

Lake Champlain has become comparatively unimportant from a purely commercial standpoint. Whether or not the improvements contemplated by the State of New York, which will result in increasing the size and capacity of Champlain Canal, will restore the lake to anything like its former importance, is questionable. At all events it will not so enhance the commercial importance of the lake that its future really great function, that of water supply, will be overshadowed. It is apparent that the highest development will be reached as a place for summer homes and as a source of municipal water supply. 

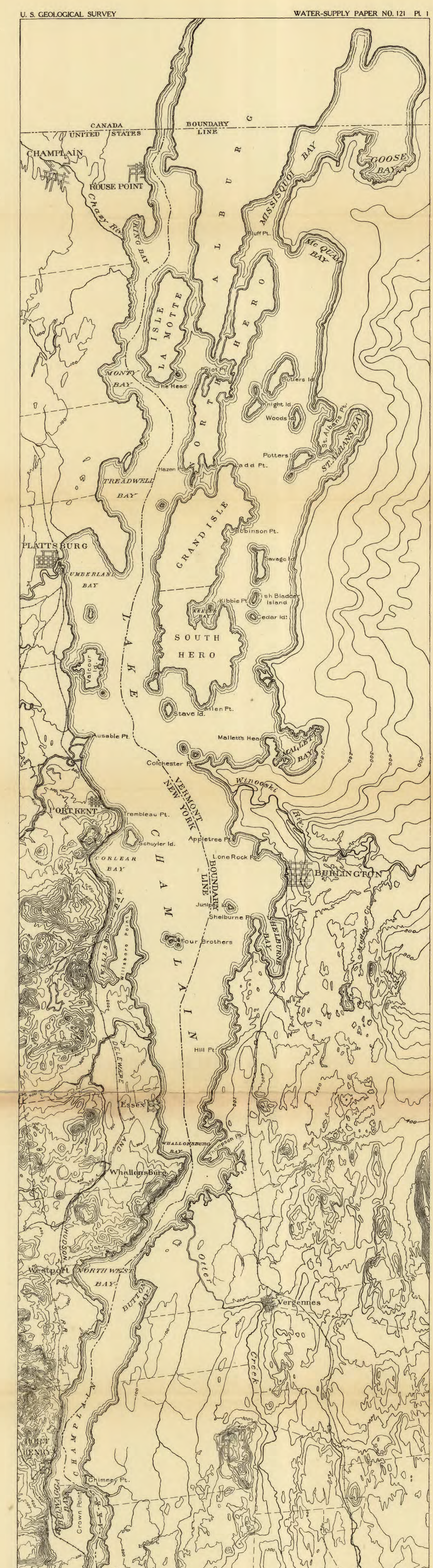

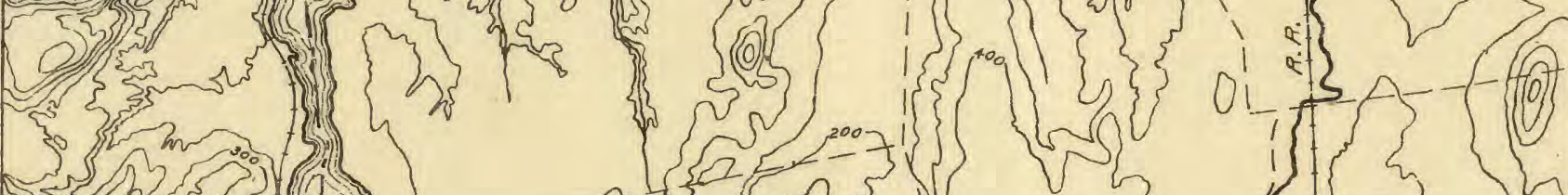
1. 年

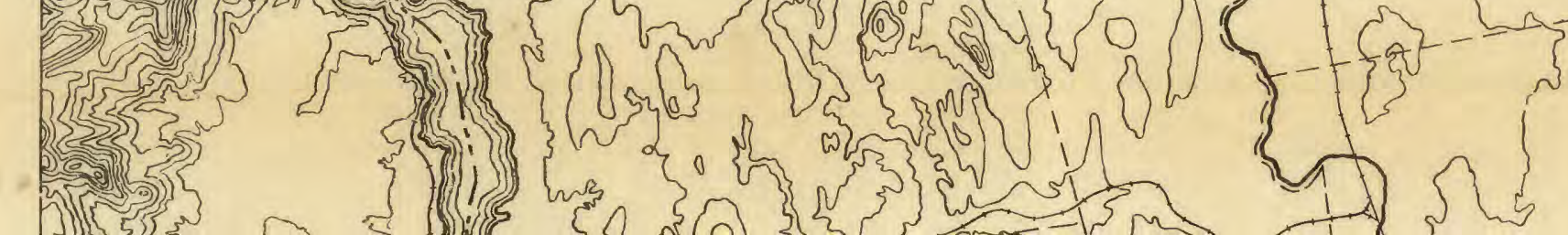

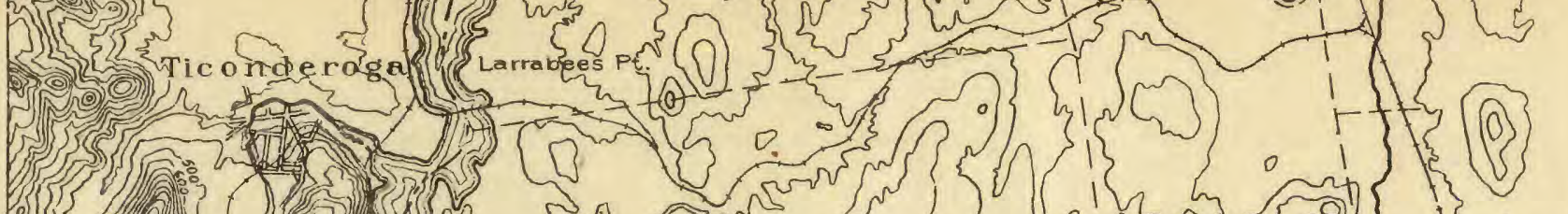
J) (25)

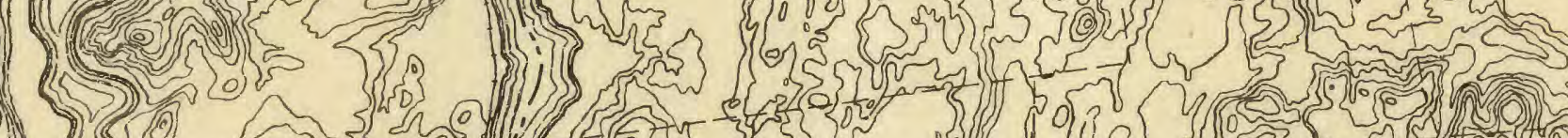
*)

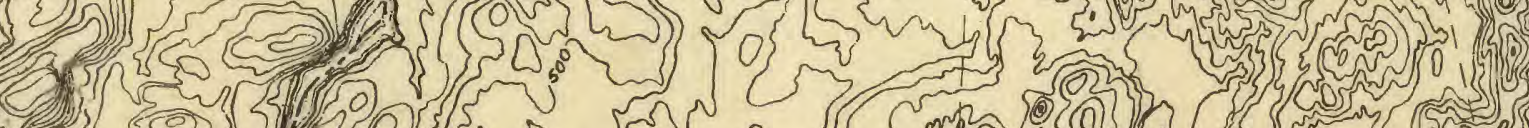
(H)

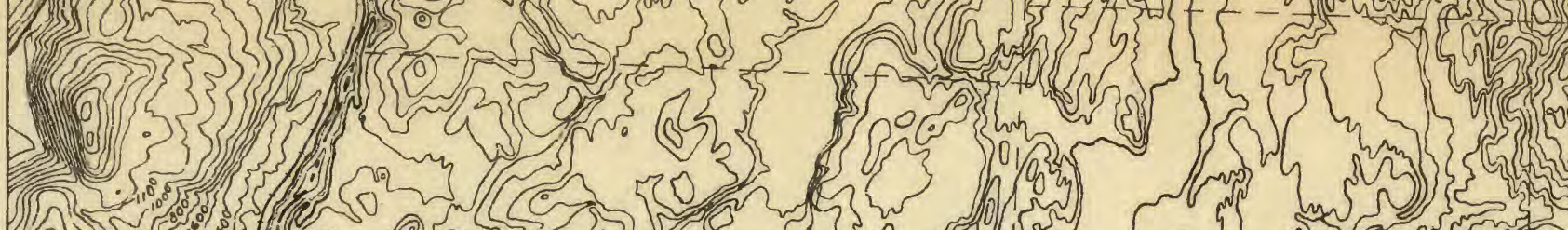

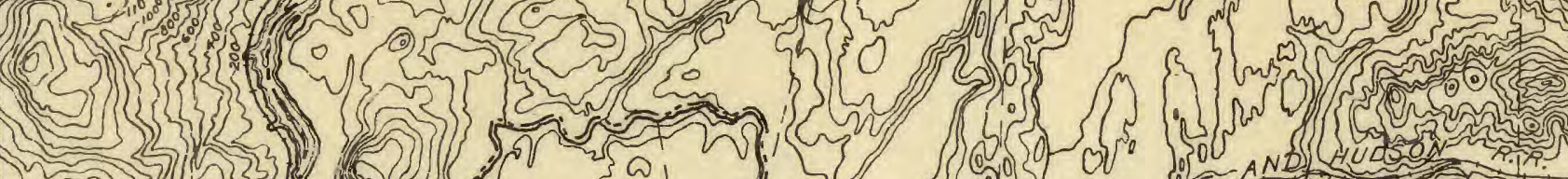
(2) 2 (3) No

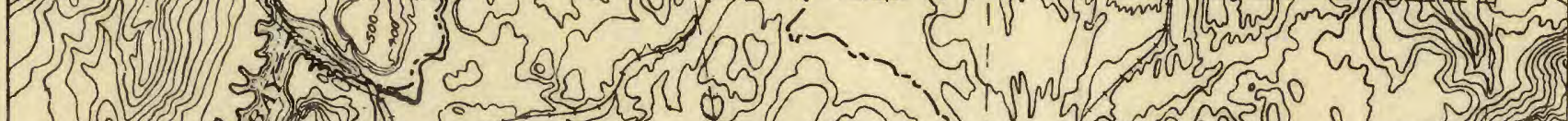
3)

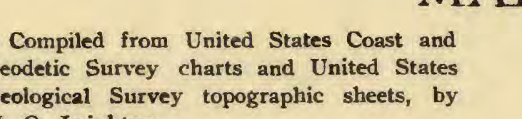


As the growth of the urban population becomes still more important, it will be necessary more and more to conserve all those bodies of water that can be retained in practically pure condition and to safeguard them for all future time. Therefore the matter of pollution dealt with in the following pages becomes a most important consideration in connection with the lake and its future.

\section{GENERAL DESCRIPTION OF THE LAKE.}

Lake Champlain is a long, narrow basin lying between the States of New York and Vermont and extending across into the Dominion of Canada. Its extreme length is said to be about 130 miles, while its greatest breadth, a short distance north of Ausable Point, is about 11 miles. The lake occupies the narrow valley dividing the Adirondack Mountains of New York from the Green Mountains of Vermont. These mountains come down close to the border of the lake for considerable distances along the New York shore, while on the Vermont side there is generally a good space of rolling country between the shore and the foothills.

The late Prof. Ebenezer Emmons, at one time in charge of investigations in the second geological district of New York (comprising the counties of Warren, Essex, Clinton, Franklin, St. Lawrence, Jefferson, and Hamilton), made a report under date of January 1, 1842, to Governor William H. Seward, in which the following observations were made with reference to Champlain Valley:

The length of this valley is $\mathbf{1 8 0}$ miles, if it is to be considered as extending to St. Johns; but it appears to open into the valley or basin of the St. Lawrence 20 miles to the south. The greatest depression of this valley is between Westport, Burlington, and Port Kent. By sounding close to the edge of the perpendicular rocks, about 4 miles north of Westport, I found the depth to exceed 300 feet. By soundings at other places in this part of the lake its depth has been found to be 600 feet; it extends; therefore, 500 feet at least below the level of the ocean. Situated as the lake is, entirely upon the western side of the valley, its bed must be regarded as a deep chasm principally in the primary rocks; for from the lake shore upon this side the slope is abrupt along the whole portion where the several mountain ranges reach it, except in those portions of it which are bordered by the minor valleys. The character of the slope upon the east side is quite different from the west; that is, it is longer and much more gradual in its descent; it comprehends most of the valley. In a direct line, or a line perpendicular to the course of the lake and the Green Mountain Range, it can not exceed 25 miles, and probably the average width of this valley is about 20 miles. At many places the lake is bordered by steep banks composed of clay and sand, the greatest height of which is about 100 feet. It is not my purpose, in this place, to consider the nature of this formation or its age, -but it is proper to remark that it is marine, as at many points it furnishes an abundance of fossils belonging to those species which are now inhabitants of the sea on the Atlantic coast-those, too, which belong to the same latitudes. Thus, I have found the Mya arenaria, Mya truncata, Natica clausa, Tritonium anglicum, Tritonium fornicatum, Scalaria groenlandica, Saxicava rugosa, Tellina groenlandica, Balanus miser, Pecten islandicus, Terebratula psittacea, Modiola_—, and several other shells, amounting in all to about twenty species, all of which, as has been remarked, belong to the pres- 
ent Atlantic shore. We may therefore consider the sediment of this valley as quite recent, and, in addition to this, as having undergone but little change since the marine occupants gave place to the lacustrine.

On the New York side there are several small and unimportant valleys which open into the Champlain. The most important are those of Lake George, which has already been spoken of as extending to the plains of Saratoga, the Bouquet, Ausable, and Saranac. The Bouquet is narrow and runs nearly in the direction of the lake for about 8 miles, along the junction of the primary with the transition rocks. The Ausable is much more important, and is geologically interesting for the gorges in the Potsidam sandstone through which the Ausable flows. The river flows near the southeastern side of this valley, and it is not improbable that it would be proper to consider the Ausable and Saranac as but one valley. Considered as one, it extends 20 miles west of the lake, and north till it terminates in the valley of the St. Lawrence. It lies in the angle formed by the great Adirondack on the south, and Lyon and Whiteface on the west and northwest. It extends, therefore, from Keeseville to Champlain, and from Plattsburg to Redford. Geologically, this valley is important and interesting, particularly as it furnishes a better development of the lower transition rocks than any other part of the State. It is only here that we find the series complete. The phenomena, too, of uplifts and fractures are finely displayed, in addition to which, all the elementary principles of geology may be found illustrated in a field quite accessible.

I have only to notice one other feature in the valley of Champlain, viz, the obliquity of its subordinate valleys. Thus, on the west, or New York side, they open to the northeast; on the east, nearly to the northwest; though as it regards the latter, their course coincides more nearly with the direction of the Green Mountain Range. Thus, the valley of Otter Creek coincides very nearly with that of the lake, or with a north and south direction. These facts, it is true, are unimportant in themselves, and they are only noticed for the purpose of showing more clearly the slope and convergences of the valley. It is only by these facts that this structure can be demonstrated.

The question concerning the age of valleys is quite as important as that of the mountain system. In many instances these two inquiries are connected and inseparable from each other, or the determination of one settles that of the other. Though it is difficult to determine the question under consideration with much exactitude, still there are two or three facts which are important: It is a very ancient valley, a fact which is proved (1) by the organic remains of the clays and sands which form the present floor of the valley; (2) by the smooth and polished surface of the rocks which compose the ancient floor upon which the clays and sands of the post-Tertiary (as the formation has been designated) were deposited, for we can not regard them as having been wholly formed by sudden and violent movements of the loose materials upon the surface. The whole phenomena is one of moderate force, combined with one of power, but yet of long continuance.

The ancient floor of this valley is formed by two classes or systems of rocks: (1) The primary, principally gneiss, and (2) the lower transition, or rocks of the Champlain group, as they are denominated in the subsequent pages. The order of events connected with the formation of this valley may be stated thus: First, the primary rocks, which constituted the floor of an ancient ocean of an unknown extent. Upon these were deposited the sandstones, limestones, and shales of the Champlain group. Thus far the series of rocks appear to be whole and perfect, or without breaks, but after the completion of this group the ocean retired and they became the surface rocks. Subsequent to this, an elevating force deranged the horizontality of the masses, fracturing them extensively in the line of the present valley, and raising them above the waters of the ocean. This line of elevation and of fracture runs close upon the. western shore, and merely breaks off the western edges of 
the transition. In the third place, we find a current or flood of waters to have swept through this valley and to have removed to a great distance the loose materials of the surface, and by their means to have worn down and polished the surface of the rocks which were exposed. Fourth, we find this valley again occupied by an ocean in which deposits were again accumulating, principally aluminous or of clay, but mixed with calcareous matter in the middle portion and siliceous in the upper. This state of thingsdid not exist long, for the marine relics are few and the formation deposited limited and thin, probably not exceeding 100 feet. In its turn this formation was elevated, and became exposed to currents of water bearing along rocks and stones, being in some places entirely swept away; in others, only the sandy portion, or the upper part; in others it remains entire, especially where it was protected by jutting rocks; thus the stiff blue clay of the inferior portion, the yellow and brownish of the middle, and the sand of the upper, all remain undisturbed. It is in the last two that we find the modern shells principally near their junction. The last sweepings of this deluge of waters formed the present bowlder system, and we find the latter always above the former, or post-Tertiary. Such have been the vicissitudes of this beautiful valley. Twice have the waters of the ocean reposed upon its bosom, and twice has it been swept, as it were, with the besom of destruction. For a long period after the deposition of the Champlain group it remained above the watery element, or during the whole period required for the deposition of the New York transition system-the old red, the Carboniferous, the Secondary, and the great Tertiary; after which, for a short period, it was once more under the sway of Neptune, and the monsters of the deep once more took possession, and the iceberg floated upon its waters. But this state was to be transient, for it was already fitted for the abode of man; the waste was to be reclaimed; the time had already come for man to assume the power and erect his temples in the vale. How long the present floor of this valley has existed can not be told with any exactness approaching to a demonstration, but it is manifest that it is comparatively recent, for the materials being soft would ere this have been entirely removed and the beds destroyed had they existed during the epochs of the Eocene Tertiary, especially in those places where they are exposed to abrasion by rains and floods. Even deep furrows are worn annually in the sands and clays, and they are perceptibly diminishing in extent.

The maximum depth of the lake is 399 feet. Examination of the mariner's chart shows that throughout the greater portion of the lake the depth of water is more than 100 feet.

The head of the lake is at its southernmost end. This is a spot somewhat difficult to determine. Examination of Pl. I will show that from the end of Crown Point south to Whitehall the lake grows constantly narrower, merging gradually into a small stream called Wood Creek. The upper end of the lake is generally understood to be at Whitehall, but there is some difference of opinion on this point. The early settlers regarded Bulwagga Bay, west of Crown Point, as the head of the lake, and early maps designate that part lying between old Fort Ticonderoga and Crown Point, "river flowing into Lake Champlain." There is much to support this view. The current northward from Whitehall to Crown Point is readily perceptible, except when a northerly wind reverses its direction upon the surface. This part of the lake, too, is radically different from that north of Crown Point. Its width varies from a few hundred feet to about a mile, and the depth of water averages about 25 feet 
in the tortuous midchannel. The banks and bottom are of sedimentary clay, overgrown with weeds, and shoal water extends well out into the stream. The water is exceedingly turbid, and appears not unlike that of the rivers in the Middle West.

Northward from Crown Point the true lake formation is assumed. The banks diverge, the water deepens, and rocky shores take the place of clay banks. The true basin of the lake runs off steeply near the head of Crown Point. From there to the Canada line the water is without marked turbidity, save where certain outcrops of shale or clay or the sediments from tributary streams create small areas of colored water.

Between Whitehall and the mouth of Ticonderoga Creek or Lake George outlet the country on both sides of the lake is rugged. On the Vermont side the hills within a short distance from the shore rise to heights varying from 200 to 850 feet above the lake surface. The highest point is Bald Mountain, in Rutland County, 4 miles north of Whitehall. The line of hills on this side ends abruptly at Mount Independence, a historic fortification 200 feet above the lake and opposite old Fort Ticonderoga.

On the New York side is a much more precipitous line of hills, varying from 900 to 1,800 feet above the lake and terminating at Mount Defiance, the site of another colonial fortification immediately south of Fort Ticonderoga and separated from it by Lake George outlet. This range is the drainage divide between Lake George and Lake Champlain. The outlet runs around the end of Mount Defiance and enters Lake Champlain by way of the rolling country north of Mount Defiance, descending 221 feet in the intervening 3 miles.

Northward from Ticonderoga to Crown Point, a distance of about 14 miles, the lake varies in width from half a mile to a mile, the shortest distance from shore to shore being opposite the old French fort on the end of Crown Point, where only two-fifths of a mile separates it from Chimney Point on the Vermont side. The country on both sides of this portion of the lake is of a generally rolling character, except where-a short distance south of Crown Point village-Sugar Hill, Breeds Hill, and Dibble Mountain rise up from the water's edge. These prominent points are outlying foothills of the ranges farther west, the highest, Dibble Mountain, being 900 feet above the lake surface.

In colonial times the narrow pass between Crown Point and Chimney Point was believed to be of strategic importance. It was first fortified by the French, the site being called Fort Frederick, and after the English occupation an extensive fort was constructed at an expense of $\$ 10,000,000$. The place, however, was found to be of no strategic importance. No engagement of any consequence took place there, although the fort was taken several times without any defense upon the part of the garrison. The ruins shown in Pl. II, $A$, are remarkIRR $121-05-2$ 
ably well preserved, and the region is one of the most interesting along Lake Champlain. As shown on the map, Pl. I (p. 14), Bulwagga Bay occupies a considerable area to the west of Crown Point and is physiographically the southernmost boundary of the lake.

Northward from Bulwagga Bay the depth of water in the lake rapidly increases until at the point opposite Essex, some 20 miles north, the deepest water in the lake occurs. From Crown Point north to Split Rock Point the two shores of the lake are markedly different, that on the New York side being mountainous, with summits rising from 1,000 to 1,600 feet above the lake, while that on the Vermont side is decidedly flat, and even swampy around the mouths of Otter, Little Otter, and Lewis creeks. Northward from Split Rock Point the country on both sides of the lake is exceedingly attractive, although the mountains do not approach the shores on either side. On the New York side the country northward from Split Rock Mountain to the end of Willsboro Point is rolling, arable land, while that on the Vermont shore is of the same general character already noticed along the more southerly portions of the lake.

The western side of Willsboro Bay is especially marked by precipitous mountains which rise almost perpendicularly to a considerable height, forming exceptionally bold shores. This mountainous shore continues to Trembleau Point, which has been described as the eastern abutment of the largest of the Adirondack ranges. From this region north on both sides of the lake the country is rolling and the lake is dotted with many islands, some of which, like Grand Isle, are large.

Grand Isle, together with North Hero, Isle La Motte, and Alburg Tongue, form a continuous series which divides the lake into two portions. The easternmost division extends into Canada, covering there an area of 740 square miles. This portion has no outlet, it being an immense bay tributary to and not so deep as the western portion. Its banks are low and the shore is a continuation of broad shoals. The western portion of the lake is the artery of traffic, and the country bordering is of a flat, rolling character similar to that already described.

The lake finally discharges through Richelieu River into the St. Lawrence. Therefore, the general trend of the lake current is northward. Actual movement northward is perceptible with the aid of floats only in the midportions of the broad lake where there are no near-by points of land to cause deflection. On still days floats make very good progress northward, a movement, however, which is interrupted by the slightest stirring of north wind. Movements of the subsurface waters have not been studied. The current next to the shores, however, is almost invariably southward. This is especially noticeable at the mouths of the various tributary streams. In every case which the author examined the water of the streams is deflected 


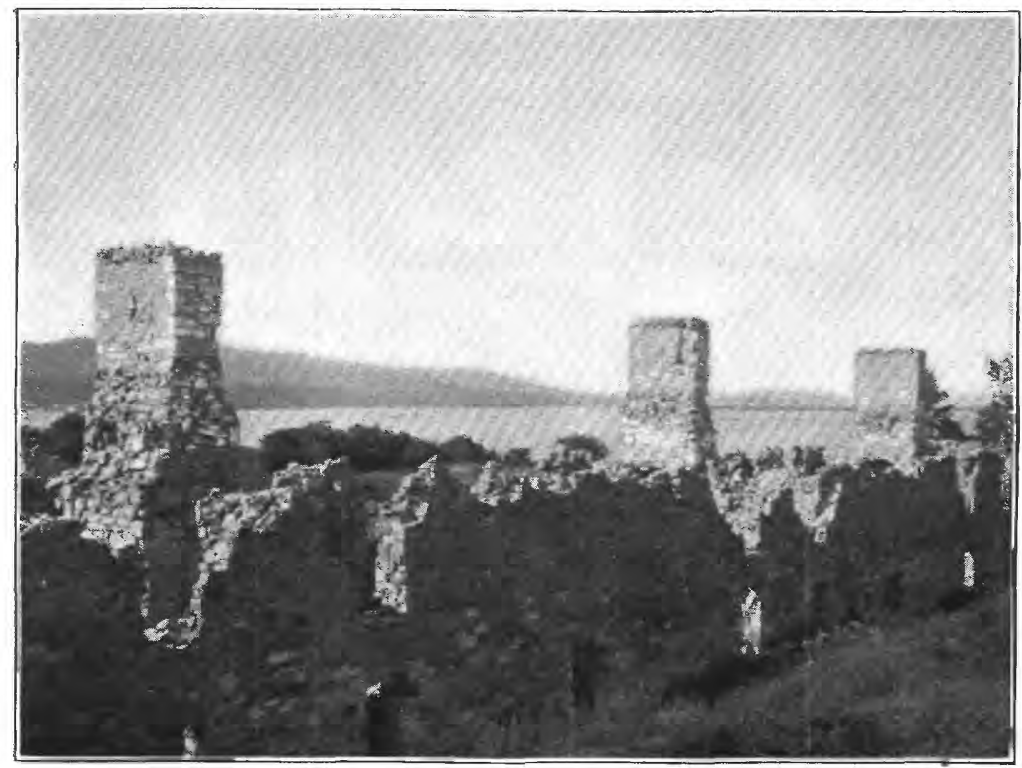

A. RUINS OF CROWN POINT FORTRESS.

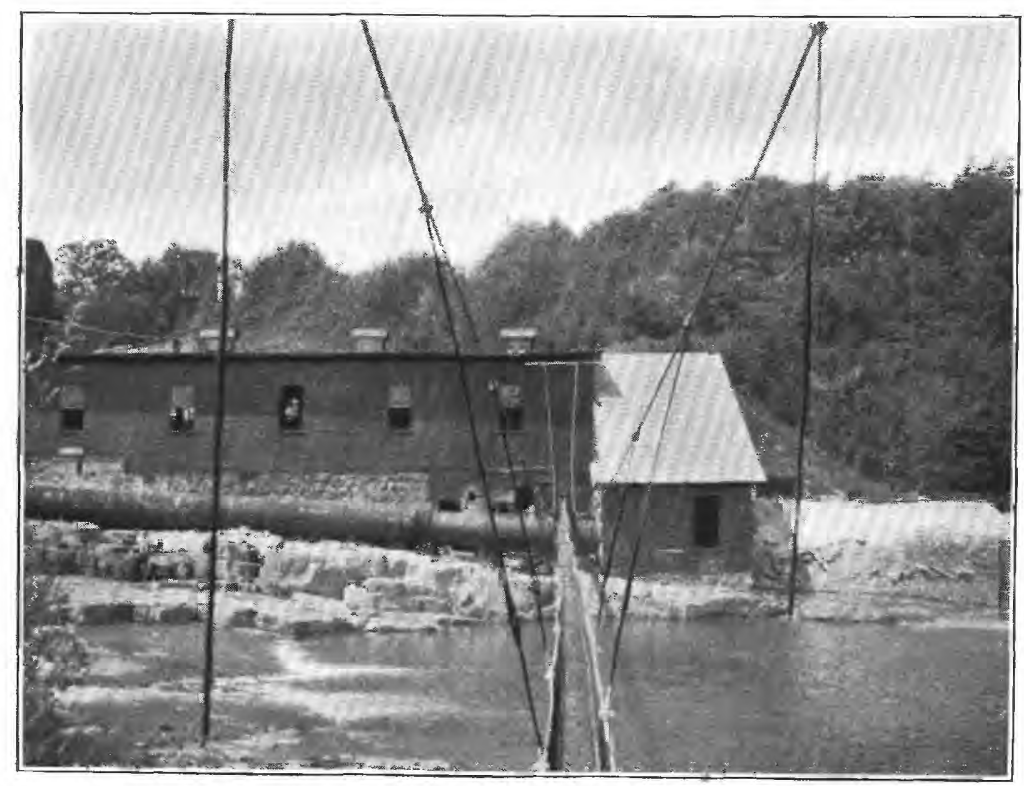

B. WASTE TROUGH CROSSING BOUQUET RIVER AT WILLSBORO MILL. 
south when conditions are normal-that is, when there is no wind. Worthy of special note is the fact that almost invariably the great sand bars at the mouths of the streams lie to the south, and whenever the water in the streams becomes turbid its course can be readily traced around the points of these bars and thence to the south, spreading ever wider and thinner until its course is no longer perceptible. Where and how this southern current is reversed and merges into the broad lake current has not been determined. The importance of the observation in this report will be noted later in connection with the studies of the wastes and their courses in the lake.

The lake intercepts many and varied geologic formations, each of which has its peculiar effect upon the character of the water immediately surrounding. It is so narrow in proportion to its length that little or no opportunity is afforded for the water draining from the several sides of the basin to become mixed; therefore, there is less uniformity in the character of the ingredients and in their proportion one to another than is usually found in lakes of similar basin capacity, but of more uniform shape. This feature is important in connection with a study of pollution, and necessitates wider investigation and more subtle interpretation than is usually necessary in an investigation of this character. In considering the effect of polluting materials of one kind or another upon a natural water it is necessary to give due regard to the character of that water. Where a given impurity will have a certain effect upon water of one kind it may have a different and possibly opposite effect upon water of another kind.

The variations in the character of water taken from various parts of Lake Champlain are so broad and the physical conditions are so dissimilar that it is necessary to interpret results differently in different portions of the lake. For example, Ticonderoga Creek and Bouquet River each carry to the lake the wastes from a soda pulp mill. As subsequent study of the conditions will show, the wastes which are derived from these two mills are practically identical. Nevertheless, the effect of the Ticonderoga wastes upon the water of Lake Champlain differs from that of the Bouquet, the reason being that the part of the lake into which Ticonderoga Creek empties is markedly different from that into which the Bouquet discharges.

The time at the disposal of the author was not sufficient to enable him to make a continuous study of the physical, chemical, and biological changes and variations which take place in the lake from point to point, it being necessary to confine the investigation to the specific matters which led to the investigation and to leave the study of other problems in abeyance until some future period. The investigations hereinafter described were therefore made with little or no reference to one another or to the general conditions which obtain in the lake other than those necessary to an intelligent interpretation. 


\section{CHARACTERISTICS OF THE LAKE WATER.}

It was necessary to secure some data concerning the normal water of the lake, or rather to secure as good an idea as possible of what the lake water would be if it were well mixed and the various ingredients uniform in proportion. For this purpose samples were collected in those portions of the broad lake which seemed to be least affected by polluting influences, whether natural or artificial.

TABLE III.-Inorganic and sanitary analyses of water from Lake Champlain.

\begin{tabular}{|c|c|c|c|c|c|c|c|c|c|c|c|c|}
\hline Sampling point. & $\stackrel{\dot{\oplus}}{\dot{\omega}}$ & $\begin{array}{l}+\infty \\
0 \\
0 \\
0 \\
0 \\
0\end{array}$ & $\dot{\mathscr{J}}$ & $\stackrel{0}{\dot{8}}$ & 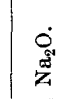 & $\dot{0}$ & 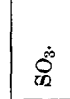 & 8 & $\begin{array}{l}\dot{0} 0 \\
0 \\
0\end{array}$ & \multicolumn{2}{|c|}{ 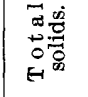 } & $\frac{d}{4}$ \\
\hline Gull Island Reef .............. & 4.8 & 1.8 & 19.19 & 4. 72 & 8.2 & 1.1 & 6,0 & 22.66 & 0.479 & \multicolumn{2}{|c|}{67.973} & \\
\hline 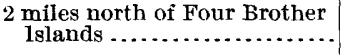 & 3.2 & .8 & 19. 19 & 4. 72 & 8.89 & 1.2 & 5.8 & 22.58 & .542 & \multicolumn{2}{|c|}{65.838} & \\
\hline Mouth of Willsboro Bay....... & 3.4 & .8 & 22.20 & 5.13 & 7.41 & 1.2 & 7.1 & 23.63 & .542 & \multicolumn{2}{|c|}{70.329} & \\
\hline $\begin{array}{l}\text { New York shore, Chesterfield } \\
\text { Township ............................ }\end{array}$ & 4.4 & 1.0 & 20.01 & 4. 63 & 8.35 & 1.4 & 5.5 & 22.83 & .63 & \multicolumn{2}{|c|}{67.49} & \\
\hline $\begin{array}{c}\frac{1}{2} \text { mile east of Four Brother } \\
\text { Islands } . . . \ldots \ldots \ldots \ldots \ldots \ldots \ldots\end{array}$ & 3.0 & 1.0 & 19.42 & 4.45 & 7.14 & 1.1 & 6.6 & 20.60 & .497 & \multicolumn{2}{|c|}{62.81} & 47 \\
\hline Average . & 3.76 & 1.08 & 20.00 & 4. 73 & 8.2 & 1.2 & 6.2 & 22.46 & .542 & 66.89 & & \\
\hline Sampling point. & & 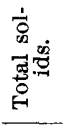 & 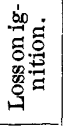 & 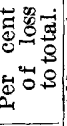 & 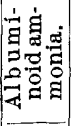 & 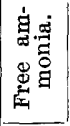 & 密 & 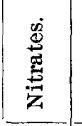 & 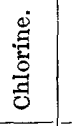 & 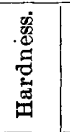 & \multicolumn{2}{|c|}{$\begin{array}{l}\dot{8} \\
0 \\
0\end{array}$} \\
\hline $1 \frac{1}{2}$ miles north of Split Rock ... & & 67.0 & 20.0 & 30.0 & 0.130 & 0.042 & 0.002 & 0.100 & 1.0 & 51.4 & \multicolumn{2}{|c|}{ None. } \\
\hline 2 miles south of Quaker Smith. & & 72.5 & 26.0 & 36.6 & .132 & .038 & .002 & .080 & 1.0 & 50.0 & \multicolumn{2}{|c|}{ None. } \\
\hline $1 \frac{1}{2}$ miles east of Jones Point..... & & 63.2 & 21.0 & 32.8 & .120 & .028 & .002 & .090 & .8 & 50.0 & \multicolumn{2}{|c|}{ None. } \\
\hline 1 mile south of Juniper Island. & & 65.0 & 22.0 & 33.8 & .156 & .032 & .002 . & .100 & .8 & 51.4 & \multicolumn{2}{|c|}{ None. } \\
\hline 1 mile west of Four Brother Isla & ands. & 60.2 & 20.0 & 30.9 & .122 & .014 & .001 & .090 & .9 & 50.0 & \multicolumn{2}{|c|}{ None. } \\
\hline Average.. & & 65.6 & 21.8 & 32.8 & .132 & .031 & .002 & .092 & .9 & 50.6 & \multicolumn{2}{|c|}{ None. } \\
\hline
\end{tabular}

Examination of Table III will afford an accurate idea concerning such water. It will be noted at the outset that the water contains a fairly high proportion of dissolved solids for this part of the country. Where in this case the water contained from 63 to 70 parts per million of total solids, Lake Winnepesaukee in New Hampshire contains 20 parts; Rangeley Lakes, in Maine, 25 to 26 parts; Moosehead Lake, in the same State, 23 to 24 parts; while the various smaller lakes and reservoirs in Massachusetis contain from 18 to 37 parts of dissolved matter per million.

The analyses given in the table furtber show that the quantities of lime and magnesia found in the water are extremely high for this part of the country, the lime running from 19 to 22 parts per million, while that in the water of Rangeley and Moosehead lakes is approximately from 2.2 to 2.5 parts. The amounts of iron, aluminum, and silica are fairly large, while the proportion of soda is far higher than in any other surface water of New England. It is essentially a carbon- 
ate water, although the amount of sulphate contained in it is proportionately somewhat greater than is usually found in this part of the United States. The chlorides are high, exceeding by about 100 per cent the normal chlorides for this region.

The sanitary analysis shows that the water contains a small amount of organic matter. The fact that the amount of chlorine is above the normal for this section is unmistakable evidence that the water has been polluted. Indeed, it is not necessary to refer to an analysis to determine this point. But the amount of organic matter in the samples under investigation certainly indicates that the water in the broad lake is of satisfactory quality. The amount of albuminoid and free ammonia is considerably less than that contained in several normal surface waters of New England, while the nitrites and nitrates give insignificant testimony, save that in the case of the latter it is shown that oxidation has been rapid and abundant. No bacteria of intestinal origin were found in this water. As might be expected from the large amount of calcium and magnesium noted in the inorganic analyses discussed above, the water is very much harder than that generally found throughout New England, the hardness determined by the soap method being, on the average, 50 parts per million, against 2 to 12 parts in the lakes and reservoirs of New Hampshire, Massachusetts, and Maine.

Although the character of the water in Lake Champlain is variable according to the point from which the water is derived, it is believed that the standards set forth in the table are representative of the water in the broad lake and that they can be used for purposes of comparison in the studies with reference to the effect of soda-pulp-mill pollution from Bouquet River, sulphite-pulp-mill pollution from Ausable River, and sewage pollution from the city of Burlington and Winooski River. In considering the effects of the soda mill upon Ticonderoga Creek, which will complete this report, another standard presented in subsequent pages will be adopted for comparison.

\section{BOUUQUET RIVER.}

\section{ORIGIN, COURSE, AND FLOW.}

Bouquet River is a small Adirondack stream rising in Keene Township, Essex County, N. Y., in the Adirondack Mountain Reserve at the foot of Dix Mountain. Its source is at an elevation of about 3,500 feet above sea level, in a ravine known as Hunters Pass. It flows in a general northwesterly direction, and is joined by South Fork near the point at which the river crosses the Keene Township line into Elizabethtown. Continuing northwestward the stream emerges from the mountain gorges and flows for several miles in a broad, open valley, known as Pleasant Valley, until it reaches Elizabethtown, the 
county seat of Essex County. Thence it flows in a general northwesterly direction across the outlying ranges of the Adirondacks and finally emerges upon the rolling table-land (Pl. III, $A$ ) next to Lake Champlain at Whallonsburg, a village in Essex Township; thence its course is almost due north to Willsboro village, where it takes a sharp bend to the southeast and enters Lake Champlain. About 8 miles from its mouth it is joined by North Branch, which drains a considerable area in Chesterfield and Lewis townships, in the heart of the Adirondacks.

The Bouquet system is useful in a small way, for its rapid descent affords opportunity for many small powers, some of which are utilized for sawmills. The largest power along the stream is about 3 miles from the mouth, at Willsboro village, where there is a fall of about 30 feet, utilized by a saw and grist mill and by the Champlain mills of the New York and Pennsylvania Company (Pl. III, $B$ ), which are devoted to the manufacture of "soda pulp." Throughout its course the river drains a sparsely inhabited region, the few villages along its banks contributing very little contaminating matter. Above Willsboro the principal source of pollution is sawmills, from which immense quantities of sawdust are turned into the stream during every season. In this respect Bouquet River is similar to almost every other stream which runs out of the Adirondack Mountains. The importance of this will be discussed in subsequent pages.

The flow of Bouquet River fluctuates widely with the season. At times it sustains violent floods, while on the other hand seasons of low water are extreme. The only flow measurements which have been made were carried on during the prosecution of the investigations here reported. The data acquired were collected during an extremely dry season, and afford an excellent idea of the minimum amount of water which the stream may be expected to carry. For this reason the records are valuable in connection with the pollution investigation, for computations based upon them will represent the most grievous conditions from the standpoint of pollution. Effects and deductions made from them will therefore be based upon extreme conditions.

Table IV contains a record of the flow of Bouquet River during a period specified. 


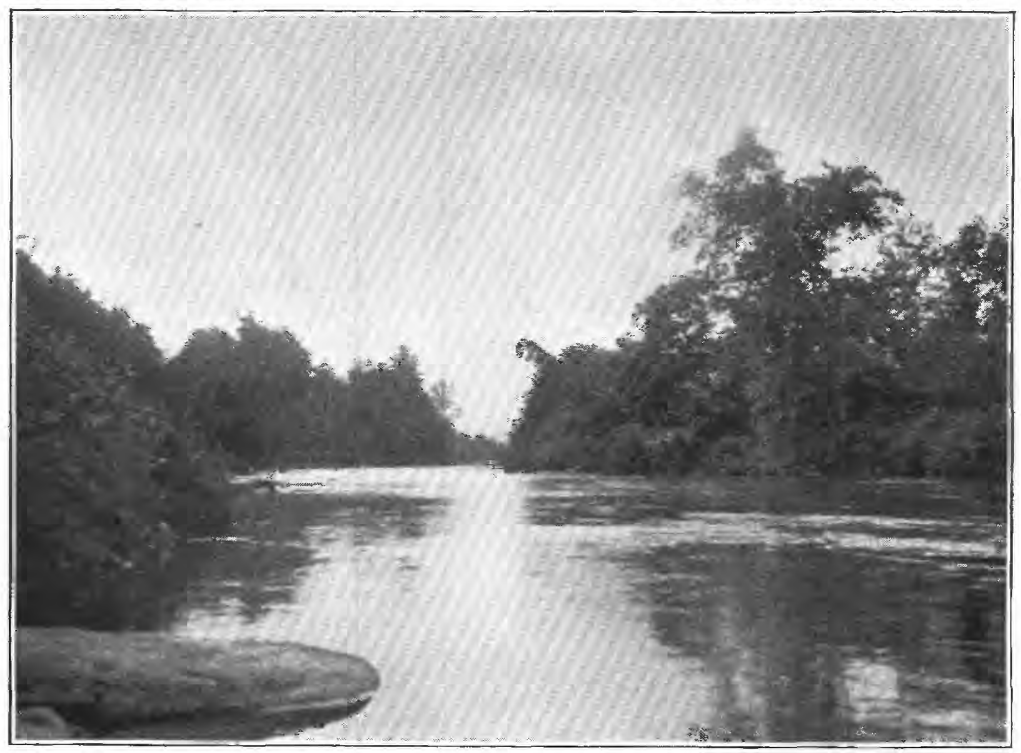

A. BOUQUET RIVER ABOVE WILLSBORO.

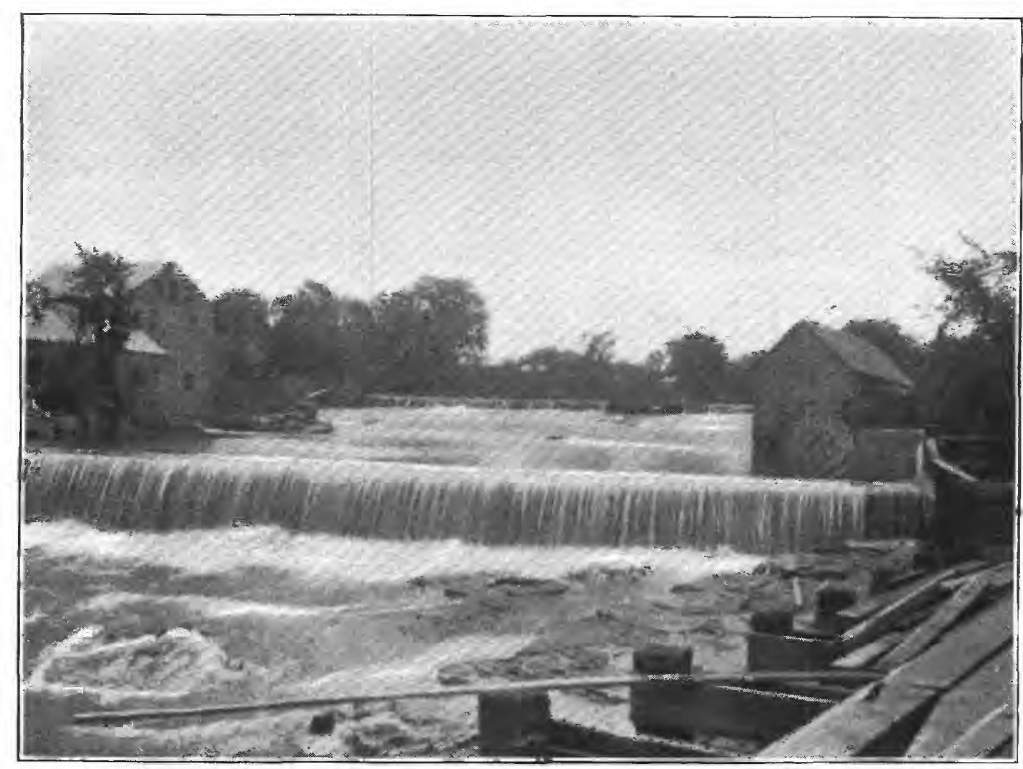

B. FALLS IN BOUQUET RIVER AT WILLSBORO. 
TABLE IV.-Mean daily discharge of Bouquet River, in cubic feet per second, at Willsboro, N. Y., August 2 to September 3, 1904.

\begin{tabular}{|c|c|c|c|}
\hline Date. & Discharge. & Date. & Discharge. \\
\hline August $2 \ldots$ & 92 & August $19 \ldots$ & 89 \\
\hline August $3 \ldots$ & 99 & August 20 . & 89 \\
\hline August $4 \ldots$. & 92 & August $21 \ldots$ & 601 \\
\hline August 5 .... & 92 & August $22 \ldots$ & 283 \\
\hline August $6 \ldots$ & 89 & August $23 \ldots$ & 169 \\
\hline August $7 \ldots$ & 89 & August $24 \ldots$ & 169 \\
\hline August $8 \ldots \ldots \ldots$ & 89 & August $25 \ldots \ldots$ & 109 \\
\hline August $9 \ldots \ldots \ldots$ & 89 & August $26 \ldots$ & 98 \\
\hline August $10 \ldots$ & 89 & August $27 \ldots$ & 89 \\
\hline August $11 \ldots$ & 89 & August $28 \ldots \ldots \ldots$ & 89 \\
\hline August $12 \ldots \ldots \ldots \ldots$ & 89 & August $29 \ldots \ldots$ & 89 \\
\hline August $13 \ldots$ & 89 & August $30 \ldots \ldots . . . . .$. & 92 \\
\hline August $14 \ldots$ & 89 & August $31 \ldots \ldots \ldots \ldots$ & 89 \\
\hline August $15 \ldots$ & 89 & September $1 \ldots$. & 89 \\
\hline August $16 \ldots \ldots \ldots \ldots$ & 89 & September $2 \ldots \ldots \ldots \ldots$ & 89 \\
\hline August $17 \ldots \ldots \ldots$ & 89 & September $3 \ldots \ldots \ldots$ & 89 \\
\hline August $18 \ldots \ldots \ldots \ldots$ & 89 & & \\
\hline
\end{tabular}

SODA-PULP POLLUTION.

CONSTITUENTS OF THE PULP.

Wood pulp consists mainly of finely divided cellulose and is the essential constituent of a certain class of paper. It is manufactured either mechanically or chemically. Mechanical pulp is finely ground wood, made by exposing the wood under heavy pressure to the surface of a revolving grindstone, which results in tearing the wood fibers apart. As this kind of pulp contains all the wood ingredients, there is no waste from the process save varying amounts of the fiber itself which escape in the process of handling. Chemical pulp, on the other hand, is made by dissolving out of the wood all the ingredients except the cellulose and leaving the latter in nearly pure state. It follows that this process results in two products-the cellulose or pulp, and the extractives. The former is the real product and the latter the by-product or waste.

Cellulose is the most abundant constituent of plant life and forms the structure of all plant forms. It may be described as the framework by which the plant raises itself and maintains its form and position. To external agencies cellulose is extremely resistant; in fact, it is one of the most chemically inert bodies occurring in nature. It is composed of 44.2 parts of carbon, 6.3 parts of hydrogen, and 49.5 
parts of oxygen-a combination so stable that only the most violent chemical methods will change its character. This fact is important because, as will be seen in subsequent pages, wood pulp forms a considerable proportion of the waste from some pulp mills, and because, like all other substances, its final effect upon a stream or other body of water into which it is turned as waste is determined by its stability and its resistance to putrefactive changes.

On the other hand, the extractives of wood-that is, those substances which are separated from the cellulose in the process of woodpulp manufacture - are organic compounds of an extremely unstable nature, undergoing putrefactive changes readily. It will therefore be appreciated that in the consideration of damage done to watercourses by pulp mills, the attention must be devoted to the extractives rather than to the inert and resistant cellulose.

In investigations of this character it is desirable to determine certain stable and persistent substances in the waste and to direct the investigation toward the identification of those substances in the water rather than to conduct the promiscuous chemical examinations so frequently resorted to in such cases in the hope that the data derived may finally produce something which bears upon the object in view. Therefore in this investigation, as well as in others reviewed in subsequent pages, it will be the endeavor to determine the most characteristic and most stable foreign substances in the waste, and to trace them directly into the lake. In order that the wastes turned into Lake Champlain through Bouquet River from the Willsboro pulp mill may be identified and their effect intelligently interpreted, it will be necessary to consider in some detail the actual process of soda-pulp manufacture.

\section{MANUFACTURE OF SODA PULP.}

In considering the process of soda-pulp manufacture, that employed at the Willsboro mill will be taken as a typical example. Although it differs in some respects from the method followed at other mills, as does that followed at any other mill differ from every other, all are essentially similar.

In the case of this mill (Pl. IV, $A$ ) the process used is based upon the hydrolytic treatment of wood chips at a high temperature in the presence of caustic soda. The process extends to a virtual isolation of the cellulose and the conversion of the extractives or lignone into soluble form. The process is similar to that which has been employed for many years in the recovery of cellulose from materials other than wood, and in the case of wood is adapted only to the conversion of soft species, poplar being used almost exclusively. 


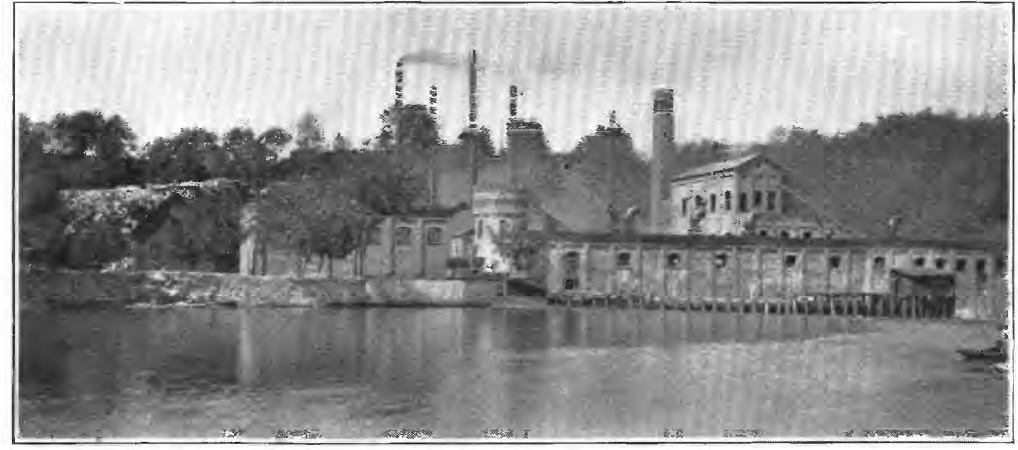

A. SODA PULP MILL AT WILLSBORO,

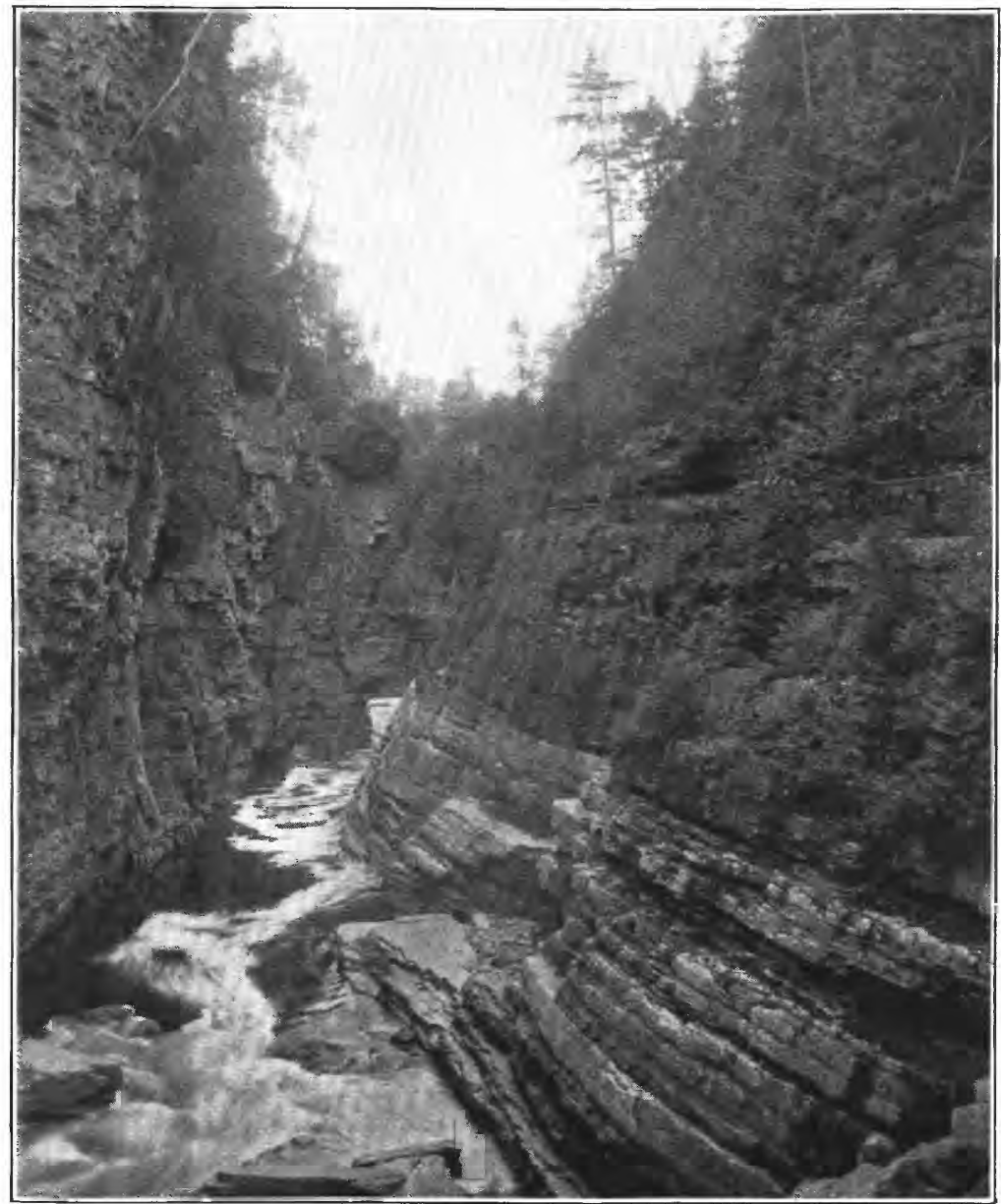

B. AUSABLE CHASM. 
WATER USED.

The mills at Willsboro are made up of several structures, some of which are used in the actual manufacture of pulp for paper products, while others are used to carry on certain appurtenant processes involved in the recovery of valuable products and their preparation for further use in the industry. It will be helpful to remark at the outset that the various details of the whole system of manufactures are so correlated that in numerous instances the liquid wastes which are the result of certain treatment are either pumped back to repeat their duty or are used in some other treatment. Therefore the total amount of water consumed in the various treatments is apparently far greater than that supplied to the mill.

A mechanical filter installed at the plant is used to clarify all the water supplied for manufacturing purposes. Measurements of the amount of water drawn from the clear-water basin show that the consumption is equivalent to an average of about 800,000 gallons per day. This water represents the total amount which enters into the manufacturing processes from which wastes are derived.

On the other hand, there is so large an amount of water evaporated during the various stages of the processes from crude wood to finished pulp that the amount of tailings finally turned into the sedimentation beds and into the stream direct is not so great as the amount supplied as clear water by the filters. Assuming, however, that the liquid wastes turned into the stream amount to the entire 800,000 gallons, and basing a calculation upon the minimum flow of Bouquet River, shown in Table IV, namely, 89 cubic feet per second, the proportion of mill waste to water flowing in the stream is about 1 to 72 ; that is, with the river flowing 89 cubic feet per second, a very low stage, there is 72 times as much water in the stream as is turned in from the mill. During the greater part of the year, when the stream carries a far greater quantity of water, the proportion of waste to water is considerably less, and in floods it probably becomes negligible.

SUPPLIES AND WASTES.

Poplar logs, 4 feet in length, are cut to thin shavings or chips in a chipper and are carried by air blast to a storage bin in the top of the digester house. From this bin the chips are dropped through properly constructed flues into the digesters. The digesters, 4 in number, are 27 feet high, 7 feet wide, and have a capacity of 3,848 cubic feet. Each charge of chips consists of approximately 4 cords, which, when digested, make about 4,500 pounds of dry pulp. Upon each chip charge are poured 3,600 gallons of caustic-soda solution having a specific gravity of 1.081 (11 ${ }^{\circ}$ Baumé or $16.42^{\circ}$ Twaddell). This corresponds to approximately 6 per cent of $\mathrm{Na}_{2} \mathrm{O}$. The mass is digested eight hours at a pressure of 110 pounds of steam. 
After the digestion process is completed the pulp is forced under pressure into a blow pit, whence it is taken into large wash pans and thoroughly washed. The drainage from these wash pans is desigaated "first liquid effluent" in this description. Its disposal will be considered hereinafter.

Sufficient water is allowed to remain in the wash pans with the pulp to reduce the whole mass to a fluid state, so that it will run by gravity through pipes without clogging. In the mill under discussion the pulp is conducted through an 8-inch pipe to another building, where it is run across sieves to remove the coarse, undigested particles. More water is added to that already mixed with the pulp, and as the mass is dashed across the mesh the efficiency of the process is increased by agitation of the sieves. The finer pulp which passes the sieves is then pumped with the same water with which it passed upon the sieves to a washer.

The washer is an oblong box about 2 feet deep, in which are 3 rotary screens, octagonal in cross section, set with their longitudinal axes horizontal. Their dimensions are such that the distance from the rotary axis to the perimeter is nearly equal to the depth of the box. This axle is set on the upper edges of the box sides. The sieve surfaces are of brass wire, 60 meshes to the inch: As the pulp passes along under the rotating sieves, the water is separated from it and pours from the sieve ends into a side trough. The pulp passes along under all three rotary sieves and is discharged into a small tank at the end of the washer box. The wash water which passes out of the sieves into the side trough will be designated the "second liquid effluent" and its disposal will be considered on subsequent pages.

Into the small tank which receives the wet pulp from the washer the bleach water, a solution of chloride of lime having a specific gravity of 1.0211 ( $3^{\circ}$ Baumé, $4.22^{\circ}$ Twaddell), is turned. The quantity of bleach water used is equivalent to the proportion of 11 pounds of bleaching powder to 100 pounds of pulp. From this mixing tank the pulp is carried to the bleach vats, which, in the mill under discussion, are 3 in number, each 18 feet deep and 15 feet in diameter. The vats are fitted with revolving arms, which effect a thorough mixture of the bleach solution and pulp. The bleaching process consumes from six to eight hours, the end being determined by the appearance of the pulp. When the bleach is complete the mass is reduced to a more fluid state by the addition of water, and the whole is pumped into large draining vats, fitted with porous bottoms through which the water runs, leaving the bleached pulp in a fairly solid state. The drainage water will be designated the "third liquid effluent" and its disposal will be considered later.

When the bleached pulp is thoroughly drained it is again loosened by a stream of water and pumped into a large storage vat, from which 
it is taken when needed, mixed in a small tank to the proper consistency with more water, and carried to fine sieves where the coarser particles which occasionally pass the first screening are removed. The material which passes this screen is then carried to the cylinder machine and is felted in the usual manner. The water with which the pulp is loosened in the bleach-drain vats, that which is run into the small mixing tank, and that supplied to the Fourdrinier machine, all take the same course and will be here designated the "fourth liquid effluent," the disposal of which will be considered in subsequent pages.

The above description includes the essential features of the process of pulp manufacture as carried on at the mills of the New York and Pennsylvania Company at Willsboro, N. Y. A summary of the materials supplied to and those drawn from the process may be expressed as follows: Supplies-wood chips, caustic soda, bleach liquor, and wash water; products-first, second, third, and fourth liquid effluents and wood pulp.

The caustic soda and bleach liquor supplied are prepared in appurtenant parts of the mill, and the wastes involved in their preparation are among the most important from the standpoint of stream pollution. The preparation of the caustic is, however, a result of the disposal of the first liquid effluent; therefore the consideration of both caustic and bleach will be postponed until after the discussion of the four liquid effluents.

FIRST LIQUID EFFLUENT.

The water drained from the wash pans after the washing of the newly digested pulp is a complex solution of dark color. Its principal ingredients are caustic soda, lignin, and various other wood extractives. It is of various degrees of concentration, according as it is drained from first washings or from later ones, the drainings from the first washings, as may be.expected, being considerably stronger than those from later ones. The washing process used at the Willsboro mill consists of storing drainage water in tanks and using it again for the same purpose until the degree of concentration is sufficiently high to permit an economical recovery of the soda. The process may be described as follows:

Three tanks are provided, to each of which runs a pipe from the wash pans. Into the first tank is conducted the strong liquor which drains from the pulp as it comes from the blow pit. The specific gravity of this liquor is about 1.0765 (10.3 $3^{\circ}$ Baumé, $15.3^{\circ}$ Twaddell). From this first tank it is pumped back into the blow pit, where it is used to reduce the digested pulp to a fluid state, so that it will readily flow through pipes and valves without clogging. In other words, the sole use of the contents of this tank is to liquefy the contents of the blow pit. After the first liquor is drained from the wash pan, wash 
water is turned upon the pulp and the drainings are turned into tank No. 2. At first the specific gravity of this liquor is about $1.0688\left(9.33^{\circ}\right.$ Baumé, $13.76^{\circ}$ Twaddell), but it is gradually diluted as more wash water is turned in. When the concentration has been so reduced that the liquor has a specific gravity of $1.0457\left(6.33^{\circ}\right.$ Baumé, 9.14 ${ }^{\circ}$ Twaddell) the remainder of the drainings are turned into tank No. 3. The contents of tank No. 2 are conducted to the soda-recovery plant.

Tank No. 3 contains the drainage from the wash pans, which by dilution has been reduced to a concentration of $6^{\circ}$ Baumé and below. The contents are used to wash the pulp after the strong liquor has been drained into No. 1, and when again drained from the wash pans it is turned into tank No. 2. This process saves the small amount of soda still contained in the final washings, and when applying it again to an unwashed pulp the liquor is again concentrated sufficiently for use in tank No. 2 and in the recovery process. The final washings of the pulp, the drainage from which is carried into tank No. 3, are made with condensed water from the Yaryan evaporators in the sodarecovery plant. The digesting and pulp-washing processes, above described, afford no waste liquors save the dripping from leaky pipe joints, valves, etc., which occasionally spring, but are of necessity repaired almost immediately. A summary of the supply and discharge from this mill is as follows: Supply-wood chips, caustic soda, distilled water, and steam; discharge-crude pulp and soda liquors. As described on previous pages, the pulp is carried across to the sieves, while the contents of the liquors, a valuable by-product, are recovered.

Recovery of soda. - The contents of tank No. 2, which have a specific gravity of 1.0457 to $1.0688\left(6^{\circ}\right.$ to $9^{\circ}$ Baume, $4.22^{\circ}$ to $8.64^{\circ}$ Twaddell), are then evaporated in Yaryan evaporators until concentrated to a specific gravity of 1.2832 to 1.3063 ( $32^{\circ}$ to $34^{\circ}$ Baumé, $56.64^{\circ}$ to $61.26^{\circ}$ Twaddell). The concentrate is then turned into rotary furnaces, where the lignin and other organic materials are burned off. The residue, issuing from the opposite end of the furnace, is composed almost entirely of carbon and sodium carbonate. This substance, known in the trade as black ash, is then passed through a leaching process, the liquid or recovered soda being conducted to the causticizing plant, while the sludge, known as black-ash sludge, remains in the bleaching tanks and is subsequently washed out with water and carried away as waste. This, then, is the first soda-mill waste met with in this discussion. The solution of recovered soda which is carried to the causticizing plant varies in specific gravity from 1.2572 to $0\left(29.66^{\circ}\right.$ to $0^{\circ}$ Baumé, $51.44^{\circ}$ to $0^{\circ}$ Twaddell), according to the leaching period.

The black-ash sludge usually contains a small amount of unleached soda. In the sample tested it was found to be equal to 171 parts per 
million-commercially an infinitesimal amount. It is probable that this black-ash sludge may protitably be used as fuel. Preliminary tests are favorable; but the final results of the determination of calorific value have not been received at date of writing.

During the years 1896 to 1903 , inclusive, there were used at this mill $89,052,686$ pounds of soda ash, of which 87.31 per cent, or $77,747,881$ pounds, were recovered soda, leaving only $11,304,805$ pounds of fresh ash purchased and applied during the entire eight-year period.

How much of this 12.69 per cent of soda ash which was not recovered at this mill during the above-mentioned period was turned into the stream can not be definitely determined. There is a considerable loss by passage of the soda to the outer air through the flues. Ash from the recovery-plant flue, which settles upon the ground about the plant, contains a large proportion of soda. The amount lost in this way has been computed by some as high as 5 per cent, but so far as the author is able to learn no positive determinations have been made.

There is usually found, in the product of this mill, about 0.112 per cent of soda. This would amount, in the eight-year period above mentioned, upon the basis of the total output-90,022,411 pounds of pulp-to 100,825 pounds. Tests show that the lime sludge from the causticizing tank, a process to be described, contains 0.0327 per cent of soda.

SECOND, THIRD, AND FOURTH LIQUID EFFLUENTS.

The second effluent, as it enters the sieves and wash tank, is derived from two principal sources. It is composed partly of the wash water turnèd into it in the final washings in the digester house. The origin of this water, as was stated in preceding pages, is the evaporators in the soda-recovery plant. The remaining part of the second liquid effluent consists of spent and weak bleach liquors, which are pumped from beneath the bleach drainers. There is a general interchange of this liquor between one process and another. From each process the liquor is carried to a weir tank in the basement of the mill, whence all the water that is needed in these processes is pumped back for use, while the excess is allowed to escape over the weir directly into the stream. A fair sample of this liquor, taken from the weir tank, contains, among others, the following ingredients:

Partial analysis of second liquid effuent.

Calcium

Magnesium

Sodium

Chlorine 513

Although this liquor contains a considerable amount of lime, soda, and chlorine, the total amount of liquor discharged directly into the 
stream is so small that its effect need not be considered apart from that of the entire waste.

The third liquid effluent is conducted through pipes, appears again as second liquid effluent, and takes the course outlined for that effluent.

The fourth liquid effluent is used in the process which produces the third effluent, and the course is repeated.

Thus it is seen that the second, third, and fourth liquid effluents are practically the same, taking the same course, and are repeatedly pumped for further duty.

CAUSTICIZING PROCESS.

This process consists of converting the soda which is recovered in the form of a carbonate, by methods above described, to a hydrate or a caustic soda, by the application of caustic lime. The process is a very simple one, requiring only the addition of an appropriate and easily determined amount of caustic lime to a similarly appropriate amount of sodium-carbonate solution, and boiling the whole mass. The result is a sodium hydrate or caustic soda in the solution, while the calcium carbonate or common lime remains in the bottom of the container as a heavy sludge. The solution is drawn off, ready for use in the digestion process, while the sludge is discharged into the sedimentation bed. This sludge is the second waste noted in this discussion. The first causticization leaves considerable amounts of soda in the lime sludge, and repeated washings are necessary to dissolve all except negligible amounts. In the mill under discussion 5 washings are resorted to and 5 cylindrical causticizing tanks are provided, each 12 feet in diameter and 10 feet deep, and the whole series is so manipulated that the causticizing and washing processes form a continuous cycle. It will be necessary to study this cycle in some detail in order that the practical absence of soda in the lime sludge discharged into the sedimentation beds may be explained.

The black-ash liquor, leached out in the recovery plant, is run into tank No. 1. As it comes from the leach it has a specific gravity of 1.2393 to $1.2609\left(28^{\circ}\right.$ to $30^{\circ}$ Baumé, $47.86^{\circ}$ to $52.18^{\circ}$ Twaddell), but during the latter part of the leaching run the concentration becomes reduced to about 1.0284 ( $4^{\circ}$ Baumé, $5.68^{\circ}$ Twaddell). As fast as the black-ash liquor accumulates in the causticizing tank, barrels of caustic lime are added until the tank is nearly full. This requires 17 to 18 barrels of lime. The contents of the tank are then agitated and boiled, and the first stage of the process is complete.

While this process has been going on the lime sludge, in another tank, in which the causticization previous to that in tank No. 1 had taken place, has been treated with water, with the result that the tank 
contains a solution of "weak" caustic soda. The process will be more clearly described in its orderly sequence in this cycle under discussion. For the present it will merely be necessary for the reader to remember that there is another tank full of weak soda liquor at hand. Whence it comes will appear shortly.

The contents of tank No. 1-that is, the caustic-soda solution, has a degree of concentration equivalent to specific gravity 1.0902 to 1.1417 (12 ${ }^{\circ}$ to $18^{\circ}$ Baumé, $18.04^{\circ}$ to $28.34^{\circ}$ Twaddell). The degree of concentration in the other tank is usually about 1.0507 ( $7^{\circ}$ Baumé, $10.14^{\circ}$ Twaddell). For wood-digesting purposes it is necessary to have a caustic-soda concentration equivalent to a specific gravity of 1.0821 $\left(11^{\circ}\right.$.Baumé, $16.42^{\circ}$ Twaddell); therefore it is merely necessary to mix the strong with the weak, or, as it is called in the trade, the "strongweak," in the proper proportion to secure the desired specific gravity of 1.0821. For example, if the strong liquor has a concentration of $15^{\circ}$ Baumé, while the "strong-weak" has a concentration of $7^{\circ}$, it will be necessary to draw off equal portions of both into the storage tank to produce a mixture of $11^{\circ}$ Baumé liquor. It frequently happens that the strong liquor is not sufficiently concentrated to produce a mixture of $11^{\circ}$ Baumé liquor if any material amount of "strong-weak" is added. The strong liquor may possess a concentration of about $12^{\circ}$ Baumé, while the "strong-weak" may be $8^{\circ}$ Baumé. Under such conditions the practice is to increase the degree of concentration of the strong liquor by adding a definite quantity of fresh-soda ash, raising the concentration in this case to $14^{\circ}$ Baumé. Then, if the two liquors are mixed in equal proportions, the resultant will be $11^{\circ}$. This, then, constitutes the point of entrance of the fresh-soda ash which compensates for the 12 per cent unrecovered (see page 29). Thus the strength is adjusted according to the conditions found.

The strong liquor having been emptied from tank No. 1, tank No. 2 is then charged and manipulated in the same manner: as that above described, while the sludge in tank No. 1 is filled and more soda is extracted from it. No. 1 is now the "strong-weak" tank. Nos. 1 and 2 are adjusted in concentration and drawn together as before. Continuing, No. 3 is filled with the causticizing ingredients and becomes the "strong" tank. No. 2, filled from the second wash of No. 1, becomes the "strong-weak," and No. 1 is treated to its third washing. No. 4 is now made the causticizing tank, No. 3 is filled from No. 2, and No. 2 again filled from No. 1. No. 4 is the "strong," No. 3 the "strong-weak," and both are adjusted and mixed. No. 4 is filled from No. 2, No. 3 from No. 1, and No. 1 refilled, making the fourth washing for No. 1. No. 5 is now made the "strong" tank, No. 4 the "strong-weak," and both are drawn. No. 5 is then filled from No. 3 , No. 4 from No. 2, while No. 3 is again filled from No. 1 . No. 1 is then filled with water and the sludge contents run upon the waste bed. 
It is then filled with the lime and soda for causticizing and becomes the "strong" tank, No. 5 becomes the "strong-weak," and the cycle is again started. No. 5, then, is the tank referred to on page 31 as "another tank," concerning which promise of further elucidation was made.

The process outlined above accomplishes a recovery of all except negligible amounts of soda used in causticizing. Its principle is most important in a consideration of stream pollution from soda-pulp mills, as it disposes of the idea that large amounts of soda are lost in causticizing, to the detriment of the stream.

PRODUCTION OF BLEACH.

The bleach plant consists of two solution tanks, each 9 feet in diameter and 7 feet deep, which are installed over a bleach-storage tank. The solution tanks are fitted with rotary agitators which are used during the preparation of the bleach liquor. In the manipulation of these tanks the governing principle is the same as that enunciated in the foregoing description of the manufacturing process-that is, weak liquors derived from second sludge extractions are used to make the strong solutions. The method of manufacturing bleach liquor at this mill is practically as follows:

Let it be supposed that tank No. 1 contains the sludge remaining after the preparation of a bleach liquor, the liquor itself having been drawn into the storage tank, and that tank No. 2 is empty. Both tanks are filled with water; in tank No. 2 are placed 1,500 pounds of bleaching powder. This is agitated for ten minutes and the suspended matter allowed to settle. The solution which these proportions of water and bleaching powder make is what is known as $3^{\circ}$ bleach, equivalent to about 4.48 ounces of bleach per gallon. This bleach is drawn into the storage tank, and immediately thereafter the clear solution from tank No. 1, which, be it remembered, is a second extraction of the lime sludge in that tank, is quickly drawn into tank No. 2, and to this are added 650 pounds of bleaching powder. This amount of fresh bleach, together with that obtained by the second extraction of the sludge in tanks Nos. 1 and 2, makes a $3^{\circ}$ bleach. The sludge in tank No. 1 is then wasted. This leaves tank No. 1 empty, and after the bleach has been drawn from tank No. 2 it contains only the sludge. It will be seen that this is the same condition which was described at the outset of this description, save that in this case tank No. 1 is empty, while tank No. 2 contains the sludge of a previous solution. The process is then repeated, the tanks alternating first with original bleach and then with an adjusted bleach.

The process above outlined involves 3 separate applications of water to the bleaching powder, reducing to a minimum the loss of available 
U. S. GEOLOGICAL SURVEY

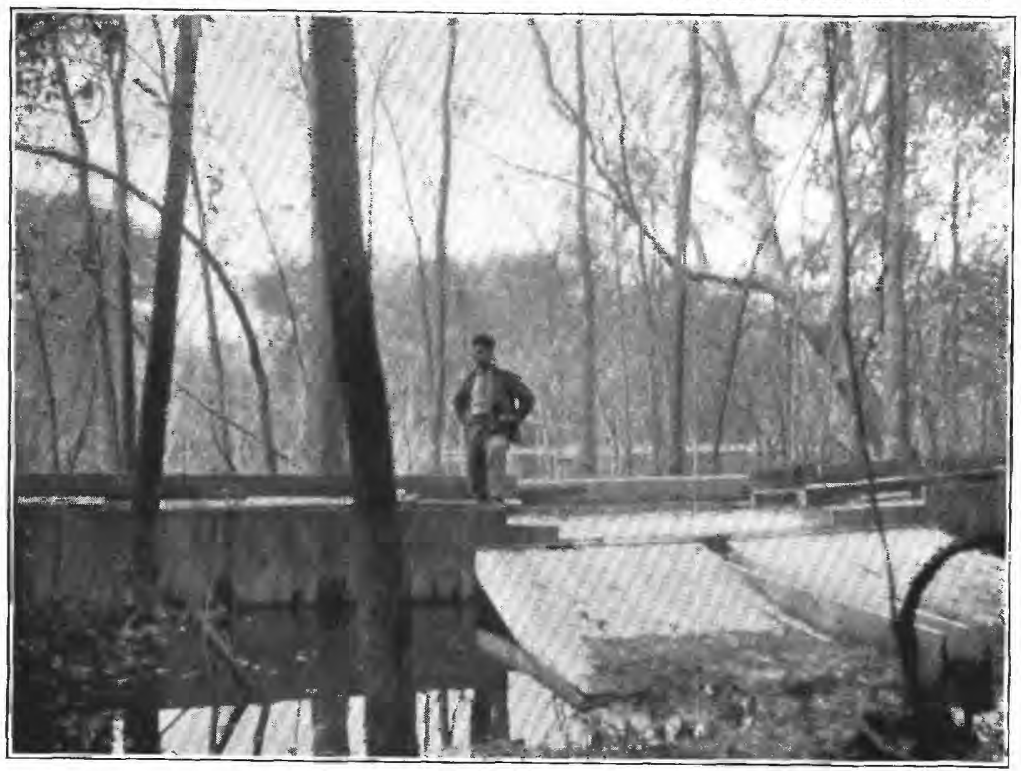

A. EFFLUENT WEIR FROM WILLSBORO SEDIMENTATION BED.

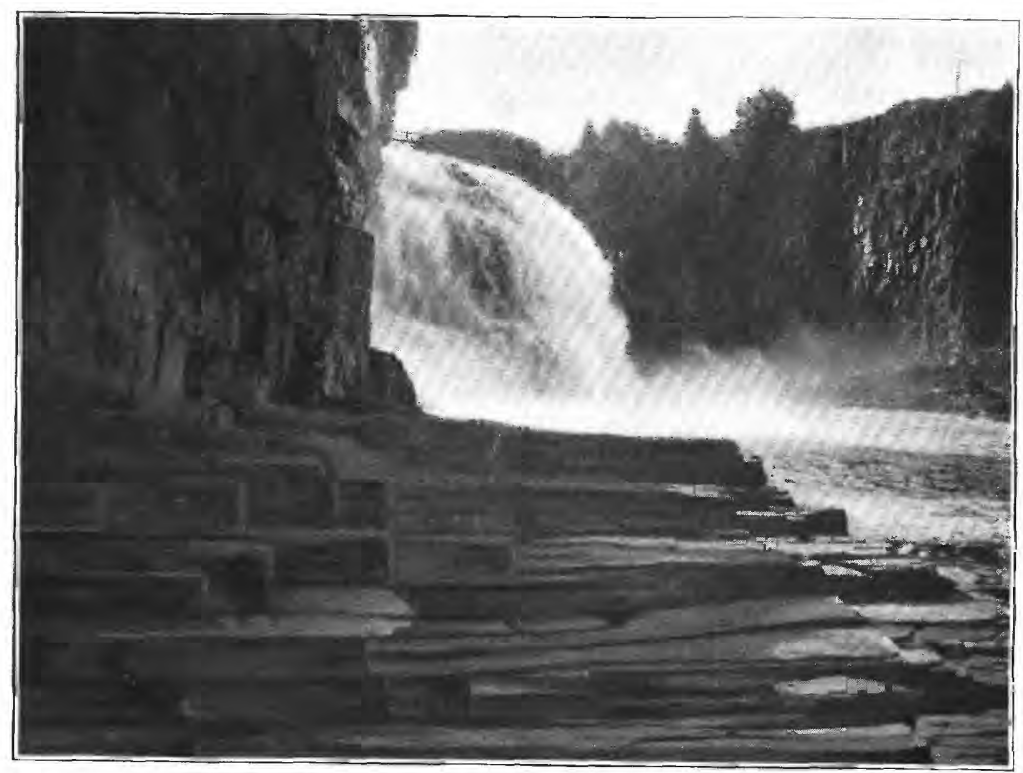

B. FALLS AT HEAD OF AUSABLE CHASM. 
chlorine. The lime sludge in the tank after the second application of water is the waste of this process. The method of its disposal will be described under another heading.

In the foregoing discussion of the process of pulp manufacture we have traced waste substances as follows:

1. The black-ash sludge and the water in which it is held in suspension.

2. The second, third, and fourth liquid effluents, which, as described, are used repeatedly, and which finally escape by being forced out by fresher waters entering through various processes.

3. The lime sludge from the causticizing process, containing a small amount of soda.

4. The lime sludge from the bleach-liquor process.

In addition to these there are occasional liquors of a similar nature which escape by reason of accidental leaks and drippings, but their quantity is so small that they do not warrant any further attention in this report.

\section{DISPOSAL OF SLUDGE.}

SEDIMENTATION BED.

The mill at Willsboro is situated below the second dam at Willsboro Falls. All of the wastes, except the second, are carried across the river in the trough shown in Pl. II, $B$, and are discharged into a sedimentation bed which covers a considerable area along the right bank of the river, from which it is separated by retaining walls. The various waste liquors run the length of the inclosed area, depositing suspended matter in transit, and are finally discharged at the lower end over a weir (Pl. V, A), and find their way into Bouquet River. All of the wastes above enumerated, except the second, enter the stream by way of this sedimentation bed. The second, not containing sufficient foreign matter to render it dangerous to any stream or at all important from the standpoint of pollution, is discharged directly into the stream by way of the tailrace.

In determining the effect of this mill upon Lake Champlain the interest centers upon wastes 1,2 , and 4 , and it is necessary to determine the result of the mixture of these substances in the bed, and the character of that which flows over the weir into the stream, in order that the important ingredients may be traced in the river and lake.

WASTES.

Waste No. 1.-The black-ash sludge should theoretically be nothing but carbon. The wood is cooked with caustic soda, the resulting products being pulp, excess soda, and the wood extractives. Poplar wood IRR $121-05-3$ 
contains, according to standard analyses, the following substances in the proportions stated:

Per cent.

Cellulose 67.77

Resin 1.37

Aqueous extract 2. 88

Water 12.10

Lignin. 20.88

The soda and all the substances occurring in the above analytical statement, except the cellulose, are separated from the cellulose by washing, and the remaining liquid is run through the recovery process. As a matter of fact this liquid contains also certain important quantities of fine pulp, which pass through the, screens. A critical examination of the substances which it contains will show that, with the exception of the soda and carbon, they are all of such a nature as to be volatilized or consumed at the high temperatures used in the recovery process. Cellulose and lignin, which make up the greater proportion of wood, are carbohydrates and are destroyed by heat, leaving only carbon in the ash. The other ingredients are either destroyed or pass off in gaseous form, leaving only soda and carbon at the end. The leaching process described separates the greater part of the soda from the residue, although there still remains, according to analyses of the sludge at this mill, an average of 170 parts of soda per million. When this is discharged into the sedimentation bed it is certain that a still further extraction of the soda from the ash is made. Aside from this, however, waste No. 1 has no effect upon the effluent from the bed.

Waste No. 3.-The lime sludge from the causticization process still retains a small amount of soda, about 327 parts per million, according to determinations made of the sludge at this mill. When this is turned into the sedimentation bed it may be expected that the soda still remaining will be dissolved and that an uncertain but small quantity of the lime will also pass into solution.

Waste No. 4.-The lime sludge from the bleach-liquor process may be expected to contain considerable amounts of chlorine, and in fact the samples analyzed did contain an average of 513 parts per million. This sludge deposited in the sedimentation bed may be expected to impart to the effluent considerable chlorine and a certain amount of lime in solution.

From what has been stated above with reference to the three wastes the conclusion may be drawn that lime, soda, and chlorine are the three principal ingredients of the effluent from the sedimentation bed. 
This conclusion is fully borne out by the following analytical statement:

TABLE V.-Partial analysis of effuent from sedimentation bed, Champlain mills, Willsboro, $N . Y$.

\begin{tabular}{|c|c|c|c|}
\hline & $\begin{array}{l}\text { Parts per } \\
\text { million. }\end{array}$ & & $\begin{array}{l}\text { Parts per } \\
\text { million. }\end{array}$ \\
\hline Total solids ..... & $4,230.000$ & Alkalinity $a_{.}$ & 1.938 .000 \\
\hline Calcium ..... & 27.020 & Albuminoid ammonia & .266 \\
\hline Magnesium . & 13.700 & Free ammonia ... & .036 \\
\hline Sodium....... & 803.400 & Nitrites......... & .030 \\
\hline Chlorine............ & 143.900 & Nitrates ... & .100 \\
\hline
\end{tabular}

$a$ Equivalent to $\mathrm{CaCO}_{3}$.

The exceedingly small amount of organic matter noted in the above table confirms what has been stated with reference to the destruction of organic matter in the process of soda recovery. The most striking feature appearing in the table is the comparatively small amount of lime which is found in solution. This is of great importance because of the fact that a large part of the objection and complaint has been based upon alleged increase of the amount of lime in the lake, to the detriment of various interests, it having been alleged in one case that the lime was the cause of a death. Twenty-seven parts of calcium per million is far below the amount found in the greater part of the water in the United States. While the composition of this waste varies somewhat from day to day, the amount of lime which is contained in it is at all times exceedingly small. This fact should be borne in mind in connection with the results of other examinations reported in the following pages.

EFFICIENCY OF SEDIMENTATION BED.

The efficiency of the sedimentation bed is confined entirely to the separation of the suspended matter from the solution as represented by the effluent. Practically no change takes place in the character of the waste. A physical examination of the effluent shows usually a clear liquor, although at times amounts of suspended matter have been noted. The sedimentation bed provided apparently serves the useful purpose for which it was erected, and, so far as the writer has been able to discover, fulfills all the requirements demanded of it. The imperfections which exist in the bed did not, during the period in which these investigations were made, result in an inferior effluent, but are rather matters of lack of economy, in which the company alone is interested. Therefore this phase of this question does not enter into the subject of pollution.

It is frequently stated, upon what seems to be reliable testimony, 
that the walls surrounding the sedimentation bed are not sufficiently high to keep out the spring floods, and that at such times the floods overtop the walls and force out the material which has been deposited there during the previous months from the mill wastes and carry it into Lake Champlain. On the other hand, equally competent testimony denies that such occasions do arise. As the evidence is about equal on both sides, the writer's opinion with regard to this waste will be based on the condition that the sedimentation bed shall be at all times effective in the separation of suspended matter from liquid and shall not at any time be invaded by floods and the contents washed into the lake.

SEDIMENTATION-BED EFFLUENT.

The character of the effluent from the sedimentation beds is therefore the question on which the whole subject of lake pollution hangs. This character, as indicated by the analytical statement given in Table $\mathrm{V}$, is that of a highly alkaline and highly saline liquor. Therefore the specific tests to be made in the water of the lake to determine the presence of this waste are those of alkalinity and chlorine. No other determinations are of value in the specific problems in hand.

EFFECTS OF WASTE ON BOUQUET RIVER AND LAKE CHAMPLAIN.

It will now be in order to follow the effluent from the sedimentation bed into the stream and down to the lake and to note the effects which it exerts upon both.

EFFECT ON BOUQUET RIVER.

Character and extent.--In considering the effect of the waste on Bouquet River it will be instructive to note (1) any changes which may take place in the amount and character of organic matter in the stream, as the results of analyses of the river at several points will be the final test of the statement that the pollution of the stream by sodamill wastes is not an organic one. In Table VI are set forth determinations of the amount and the condition of organic matter at three points in the stream-the first a considerable distance above Willsboro village, where the water is practically unpolluted; the second below Willsboro but above the pulp mill, and the third a short distance below the point at which the effluent from the sedimentation bed enters the stream.

TABLE VI.-Sanitary analyses of water in Bouquet River at three points.

\begin{tabular}{|c|c|c|c|c|c|}
\hline Sampling point. & $\begin{array}{l}\text { Total } \\
\text { solids. }\end{array}$ & $\left|\begin{array}{c}\text { Albumin- } \\
\text { oid } \\
\text { ammonia. }\end{array}\right|$ & $\begin{array}{c}\text { Free } \\
\text { ammonia }\end{array}$ & Nitrites. & Nitrates. \\
\hline $1 \frac{1}{2}$ miles above Willsboro $\ldots \ldots \ldots \ldots$. . . . & 65.0 & 0.114 & 0.022 & 0.0 & 0.300 \\
\hline Below Willsboro, above mill. ......... & 72.0 & .136 & .026 & .0 & .200 \\
\hline $\begin{array}{l}\text { Below outlet to sedimentation bed, } \\
1,000 \text { feet } \ldots \ldots \ldots \ldots\end{array}$ & 73.0 & .114 & .026 & .0 & 200 \\
\hline
\end{tabular}


It will he appreciated, upon examination of the data, that so far as the mill waste is concerned there is absolutely no evidence of any change taking place in the amount of organic matter in the water. The conditions below the outlet of the sedimentation bed, where one might expect the full force of the impurities to be concentrated, are practically the same as those in the river below the village. It is therefore clear that whatever may be the effect of the pulp mills on Bouquet River and Lake Champlain, such effects do not arise from any deposit of organic matter. The waste from these mills is entirely inorganic and can have no relation to anything allied to the subject of specific communicable disease, except, as shown in the report of Mr. Phelps (pp. 111-114), that the waste may prevent the dissemination of such disease.

From an inorganic standpoint, however, there are many interesting changes which take place in the condition of the water in Bouquet River after the waste from the mills has been turned into it. Examination of Table VII will show that there is a marked increase in the amount of calcium, sodium, and chlorine, the increase in the lastmentioned ingredient being more noticeable than any other.

TABLE VII.-Principal inorganic ingredients in water of Bouquet River at six points.

\begin{tabular}{|c|c|c|c|c|c|c|}
\hline Sampling point. & $\begin{array}{c}\text { Total } \\
\text { solids. }\end{array}$ & $\mathrm{Ca}$. & Mg. & Na. & Cl. & $\begin{array}{l}\text { Alka- } \\
\text { linity. }\end{array}$ \\
\hline $1 \frac{1}{2}$ miles above Willsboro Falls .... & 76.8 & 14.9 & 4.4 & 1.2 & 1.1 & 50 \\
\hline At falls above mill ................... & 75.0 & 15.1 & 5.8 & 1.2 & 1.1 & 50 \\
\hline Just below sedimentation bed........ & 154.8 & 17.9 & 6.7 & 3.7 & 8.5 & 57 \\
\hline 1,000 feet below sedimentation bed ... & 122.0 & 24.3 & 4. 1. & 5.9 & 8.5 & 57 \\
\hline 1,500 feet below sedimentation bed . . . . & 101.6 & 17.9 & 4.3 & 7.9 & 8.5 & 55 \\
\hline 2,000 feet below sedimentation bed . . . . & 99.0 & 17.9 & 4. 8 & 7.6 & 7.9 & 55 \\
\hline
\end{tabular}

In considering the character of this river water after it has received the waste from this mill, as shown in the analyses presented, it should be remembered that the river at the time the samples were taken was at an extremely low stage, and that during the greater part of the year the proportion of mill waste contained in the water would be far less. The Willsboro mill is operated on a steady basis-that is, the total output per day throughout the year is practically the same, and therefore the same amount of waste may be depended upon each day throughout the different seasons. The concentration of this waste in the river, however, must vary according to the stage of the stream.

It will be instructive to consider briefly how the water in the stream immediately below the sedimentation bed compares, in its proportion of inorganic ingredients, with other waters in the United States which are considered unobjectionable and freely used for drinking purposes. 
TABLE VIII.-Comparison of principal inorganic constituents in water of Bouquet River below sedimentation bed with those in various public water supplies.

[Parts per million.]

\begin{tabular}{|c|c|c|c|c|}
\hline & $\mathrm{CaO}$. & Mgo. & $\mathrm{Na}_{2} \mathrm{O}$ & C1. \\
\hline Bouquet River.. & 34.0 & 6.80 & 7.95 & 8.50 \\
\hline Yuma, Ariz....... & 39.5 & 16.59 & 194.6 & 172.37 \\
\hline San Diego, Cal ............................. & 114. 8 & 46. 30 & 266.0 & 546.00 \\
\hline Los Angeles, Cal . . . . . . . . . . . . . . & 57.8 & 15. 20 & 40.4 & 24.30 \\
\hline Pueblo, Colo.......... . & 80.7 & 12.30 & 55.6 & 20.70 \\
\hline Lake Michigan, Chicago . . . . . & 36.1 & 11.60 & 5.5 & 4. 80 \\
\hline Maquoketa, Iowa $\ldots \ldots \ldots \ldots \ldots \ldots \ldots$ & 83.5 & 33.70 & 22.2 & 33.20 \\
\hline Clinton, Iowa......... & 54.9 & 21.40 & 75.0 & 50.30 \\
\hline Mason City, Iowa ..... & 75.2 & 21.90 & 4.8 & 4. 60 \\
\hline Rockwell City, Iowa ........ & 274.0 & 87.50 & $\ldots$. & -.... \\
\hline Postville, Iowa.................... & 94.5 & 42.60 & 9.9 & 2.30 \\
\hline Council Bluffs, Iowa........... & 46.1 & 13.80 & 38.0 & 8. 50 \\
\hline Cedar Rapids, Iowa ............. & 70.5 & 36. 10 & 85.5 & 26.70 \\
\hline Waterloo, Iowa ....... & 32.1 & 33. 80 & 10.6 & 4.30 \\
\hline Dodge, Kans.......................... & 106.8 & 28.40 & 78.0 & 40.30 \\
\hline Topeka, Kans........................ & 108.9 & 22.10 & 153.3 & 145. 10 \\
\hline Argentine, Kans............. & 74.8 & 13. 70 & 39.2 & 41.60 \\
\hline Cumberland, Md.............. & 145.2 & 8.90 & 8.7 & 7. 00 \\
\hline Minneapolis, Minn.................. & 40.2 & 13. 30 & . & ........ \\
\hline Bayonne, N. J . . . . . . . . . . . . . . . . & 42.7 & 7.20 & 7.2 & 10.90 \\
\hline Mount Vernon, Ohio ........... & 76.1 & 19.10 & 15.4 & 4.80 \\
\hline Sioux Falls, S. Dak....... & 98.8 & 35.60 & 16. 8 & 3. 10 \\
\hline Houston, Tex....... & 56.2 & 5.00 & 46.6 & 48.90 \\
\hline El Paso, Tex...... & 180.1 & 26.00 & 450.0 & 393.00 \\
\hline Winchester, Va..................... & 76.9 & 16.10 & 3.9 & 6.00 \\
\hline West Milwaukee, Wis $\ldots \ldots \ldots \ldots \ldots \ldots$ & 31.6 & 10.30 & 18.1 & 2.90 \\
\hline
\end{tabular}

Conclusions.-The data set forth above show clearly that, so far as the inorganic ingredients, especially lime, soda, and chlorine are concerned, the water of Bouquet River below the entrance of the waste from Willsboro mill is preferable to many waters which are used daily for domestic purposes and concerning which no complaint is ever heard. It is true, notwithstanding, that the river is damaged by the mill. The waste which is turned into the stream contains a certain amount of wood pulp which passes through the washers and bleach drainers. This pulp is small in amount, yet from day to day it accumulates and in the course of weeks and months represents a considerable loss. It is collected in the eddies and shallow places along the banks of the stream and is found along the shores of the lake 
close to the mouth of the river, this latter amount, however, being insignificant. After an extended search along the shores of the lake north and south from the mouth, covering several miles and occupying about one-half day, the amount of pulp found here and there in isolated bunches weighed approximately 5 pounds. In the stream, however, the damage done is readily apparent. Although the pulp itself does not putrefy, it collects and holds large amounts of other débris which is putrescible, with the result that the mass becomes foul and gives off disagreeable odors. There is, too, a characteristic odor in the mill waste which is appreciable all along the stream, and can be detected in the lake at the mouth of the river when the conditions are favorable. This odor permeates the water, and while it can not be regarded as a serious nuisance, it is, nevertheless, somewhat objectionable.

The most serious feature in regard to the waste in the stream is that it gives a distinct and disagreeable taste to the fish, so that they are no longer fit for eating. Contrary to widespread reports, there are fish in this stream in considerable numbers, but their value as food is said to be entirely destroyed.

Realty values along the stream are diminished somewhat; but as there is not at present, nor will there be in the future, any great demand for the property as a place of residence, this damage is more theoretical than practical.

In short, while the stream is undoubtedly damaged by the mill, there is a compensation in the presence of the industry in that neighborhood. On the basis of public economy, there would be no hesitation in choosing in favor of the mill rather than the stream. The damage done is entirely local and probably is not felt from an actual pecuniary standpoint, while, on the other hand, if the mill were closed the loss to the community would be serious.

\section{EFFECT OF WASTE ON LAKE CHAMPLAIN.}

The observations which have been made with reference to the river and the effect which the mill waste exerts upon it can not be taken as an absolute indication of the effect of these wastes in the lake. Damage to the stream does not necessarily involve damage to the lake, nor, on the other hand, would a lack of damage to the former be an assurance of no damage to the latter. It is only upon actual investigation, involving the patient tracing out of the specific foreign ingredients in the waters of the lake, and observing the distance from the mouth of the river at which the lake water assumes the normal characteristics shown in Table III, that any definite statements can be made with reference to the subject.

Methods of investigation. - In the investigations here reported it has been the endeavor to work out the problem along these precise lines. 
Samples have been taken of the water at the mouth of the river and from this point along radiating lines running well out into the lake. These, together with the samples taken along the shore north and south of the river, give an accurate idea of the distances to which the mill waste is appreciable. In this way the data for this report have been gathered and the results of the various determinations have been grouped so that they may admit of intelligent interpretation.

The lake at the mouth of Bouquet River is well represented in Pl. VI; the prominent points to the north and to the south of the river define a small bay where the water is extremely shallow. A high sand bar, composed of materials brought down by the river, extends for about one-half mile east of the southernmost point. Between this bar on the south and the bolder cape on the north the sand has drifted, making the water too shallow for any except the smallest light-draft rowboats. Here the river empties its contents and an exceptionally favorable place is afforded for the concentration of the wastes from the pulp mill.

The investigations subsequently to be described consisted of the sampling of water at designated points and determining the amount of chlorine and the alkalinity, expressing the latter in terms of calcium carbonate. These two determinations, as above noted, are the specific ones which are best adapted for tracing the mill waste into the lake.

The initial samples in each case were taken at a central point at the mouth of the river, marked by a buoy, and all other samples were taken along lines radiating from this point, as indicated on Pls. VI, VII, and VIII. The distances between the sampling points were in all but a few cases actually determined by measurement, and buoys were permanently set at these points. In other cases, however, the distances were estimated as closely as possible by observing intersecting lines running over landmarks or by points along the shore. In the case of the shore samples taken in the last two series the distances were approximately 1,000 feet apart.

In all sample series the direction of the wind and the velocity recorded by the anemometer have been considered, and interpretations of the various results should be made according to these conditions. In an experimental series taken on August 2 it was found that the water at the surface was typical of the conditions resulting from the discharge of waste into the lake. The lower waters were, however, more uniform, generally little affected by the wastes, and therefore not good subjects of investigation. Samples were taken in all subsequent series from the surface only, and in interpreting the results hereinafter set forth with reference to the effect of the river upon the lake, it should be remembered that such results set forth only the conditions existing at the surface and that throughout the entire investigation there was 


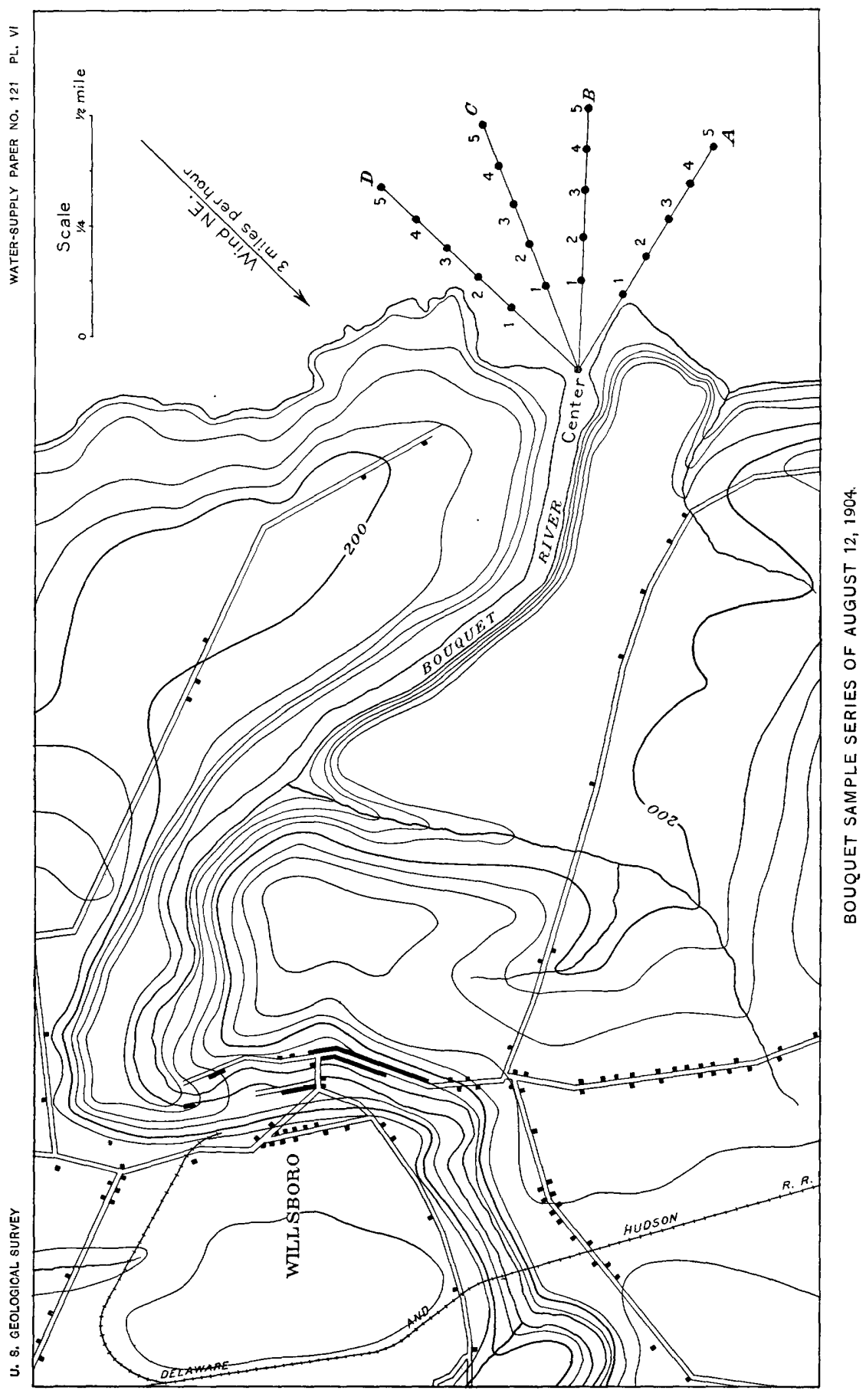


not, except in the very limited area about the central buoy, any indication of pollution from the stream in the deeper waters of the lake. Therefore the effects of the wind upon the distribution of the wastes are to be recognized more prominently in the direction from the mouth of the river toward which the wind was blowing.

Sample series of August 12.-The conditions attendant upon the collection of this series of samples are well set forth in Pl. VI. There it is shown that a light wind was blowing from the northeast. The water from the river, therefore, might be expected to take a sharp southerly turn, and little or no effect would be discernible along the outer sampling points of lines $\mathrm{C}$ and $\mathrm{D}$. Reference to Table IX shows conclusively that such inferences are unreliable. Critical examination of the figures shows that there is a marked increase in chlorides and alkalinity along the $D$ line from center to point 5 . This may be explained by the following statement: The 3-mile wind represented on the plate was that which immediately followed a change in wind direction. These samples were taken in the afternoon. The record shows that during the morning and up to about noon a strong wind was blowing from the south, and that such conditions persisted all the day previous. The wastes under these conditions were blown to the north shore, and the wind having changed so short a time before the samples were taken, and having blown so lightly, its effect was not appreciable. The condition under which the samples were taken was in reality a 10-mile wind from the south.

TABLE IX.-Bouquet River sample series of August 12, 1904.

[Parts per million.]

A LINE

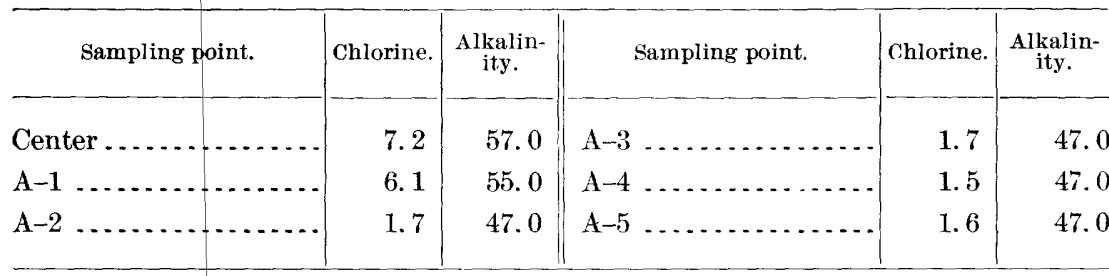

B LINE.

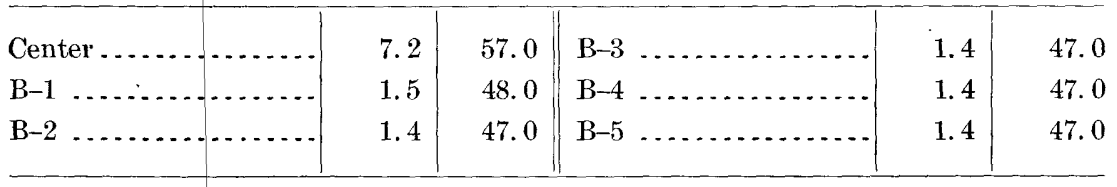

C LINE.

\begin{tabular}{|c|c|c|c|c|c|}
\hline Center ............... & 7.2 & 57.0 & $\mathrm{C}-3 \ldots$. & 1.4 & 46.0 \\
\hline $\mathrm{C}-1 \ldots$ & 1.4 & 48.0 & $C-4 \ldots \ldots$ & 1.1 & 47.0 \\
\hline $\mathrm{C}-2 \ldots \ldots \ldots \ldots \ldots$ & 1.3 & 48.0 & $\mathrm{C}-5 \ldots .$. & 1.1 & 47.0 \\
\hline
\end{tabular}


TABLE IX.-Bouquet River sample series of August 12, 1904-Continued.

D LINE.

\begin{tabular}{|c|c|c|c|c|c|}
\hline Sampling point. & Chlorine. & $\begin{array}{l}\text { Alkalin- } \\
\text { ity. }\end{array}$ & Sampling point. & Chlorine. & $\begin{array}{l}\text { Alkalin- } \\
\text { ity. }\end{array}$ \\
\hline Center ....... & 7.2 & 57.0 & $D-3 \ldots$ & 1.4 & 48.0 \\
\hline $\mathrm{D}-1 \ldots \ldots$ & 1.2 & 48.0 & $\mathrm{D}-4$ & 4.2 & 47.0 \\
\hline $\mathrm{D}-2$ & & & $D-5$ & 3.3 & 47.0 \\
\hline
\end{tabular}

In examining Table IX it should be remembered that the chlorides in the water of the broad lake which were stated in Table III (p. 20) as the standard of comparison are 1.2 parts per million, while the alkalinity is 47 parts. The results of the sample series of August 12 show an enormously increased amount of chlorine and alkalinity at the center buoy. Along the A line there is a slight decrease at No. 1, which lies close to a sand bar and is in a position to be markedly affected, while at point No. 2 the conditions are almost normal, the alkalinity being the same as in the center of the lake and the chlorine a trifle higher. These conditions are practically the same for the other three sampling points. Along the $B$ line there is practically no evidence of pollution from the mill at point No. 1, 1,000 feet from the center buoy, while at point No. 2 the alkalinity has reached the normal, while the chlorine exceeds it by an insignificant amount. The same condition persists at points 3,4 , and 5 . The evidence given by the C line is the same-that is, that 1,000 feet from the center buoy there appears to be little or no pollution from the stream, while at a distance of 2,500 feet along this line the water is the same as that taken from the broad unpolluted lake. The peculiarity shown by the $\mathrm{D}$ line has already been mentioned. The amount of chlorine in the waters at sampling points 4 and 5 is greater than that at 1 and 3 . This, as has been said, is due to the strong southerly winds which prevailed during the day previous and the first part of the day on which the samples were taken. Attention should also be called to the shore outline north of the river's mouth, which during a southerly breeze would have the effect of throwing floating impurities out into the lake at about the relative positions occupied by points 3,4 , and 5 .

The results of the determination of chlorine and alkalinity in this series of samples indicate that at a distance of 1,000 feet from the center buoy the effect has already practically disappeared at the B and $\mathrm{C}$ lines. The same is true of the $\mathrm{A}$ line at a point 1,500 feet from the center buoy, the point at 1,000 feet being very near the shore and in shallow water next to the sand bar, while at the $D$ line little trustworthy evidence is afforded because of the peculiar conditions which preceded the taking of the sample. The character of the water at 


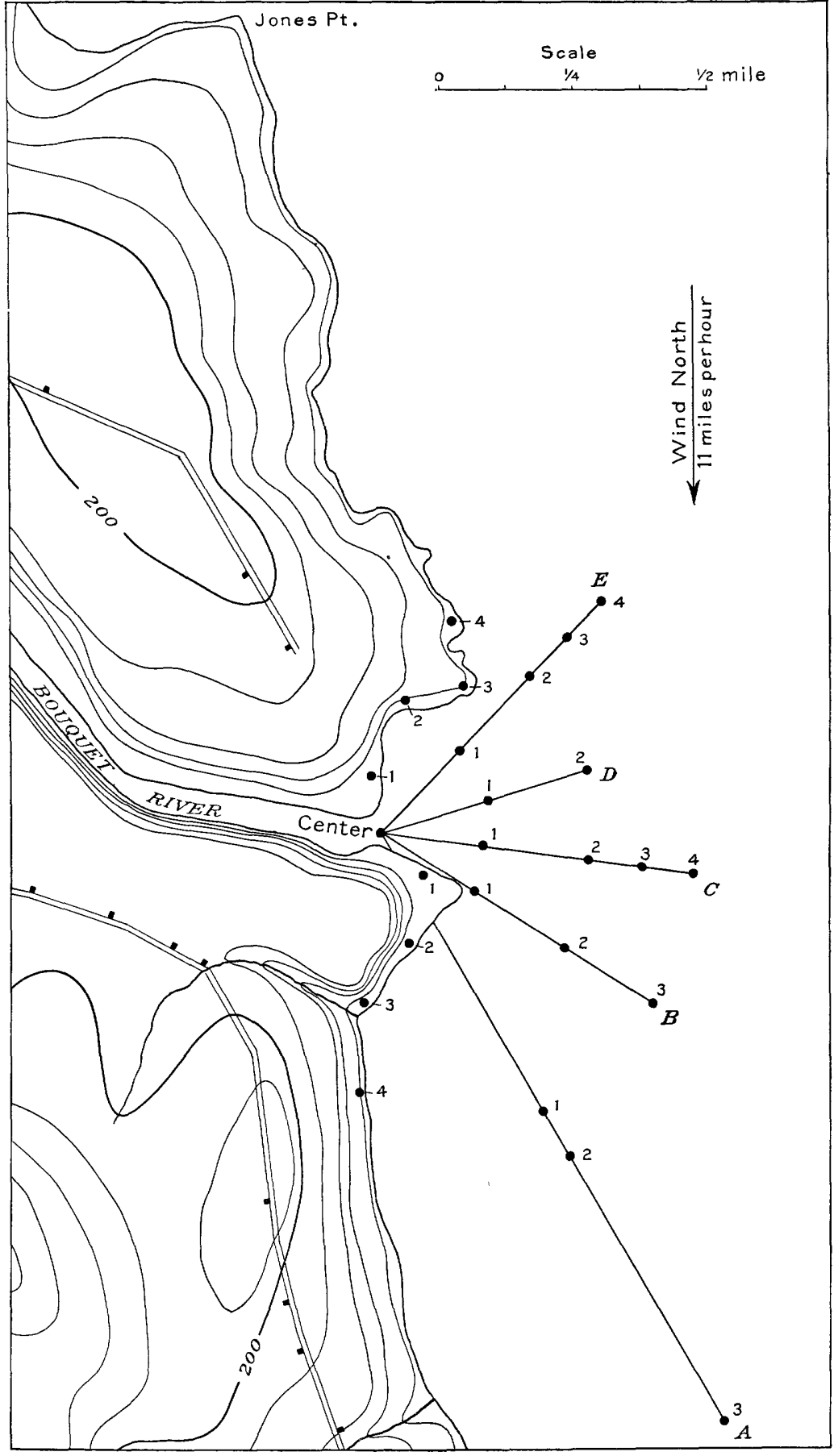

BOUQUET SAMPLE SERIES OF AUGUST 21, 1904 
points 4 and 5 on this line was abnormal only in the amount of chlorine, which, while considerable, would by no means represent a dangerous water.

Sample series of August 21. - This series was taken during a northerly breeze, blowing at about 11 miles per hour. The surface of the lake was exceedingly rough, as at this point a northerly wind has a sweep of about 50 miles of lake. Samples were taken along 5 radiating lines from the center buoy and along the shore north and south of the river's mouth. Along the A line, as shown in Pl. VII, samples were taken at distances of $2,500,3,000$, and 6,000 feet; along the $B$ line at $1,000,2,000,2,500$, and 3,000 feet; along the $D$ line at 1,000 and 2,000 feet, and along the $\mathrm{E}$ line at $1,000,2,000,2,500$, and 3,000 feet. The shore samples were taken approximately 1,000 feet apart north and south of the river's mouth. The results of the determinations are set forth in Table $X$.

TABLE X.-Bonquet River sample series of August 21, 1904.

[Parts per million.]

A LINE.

\begin{tabular}{|c|c|c|c|c|c|}
\hline Sampling point. & Chlorine. & $\begin{array}{l}\text { Alka- } \\
\text { linity. }\end{array}$ & Sampling point. & Chlorine. & $\begin{array}{l}\text { Alka- } \\
\text { linity. }\end{array}$ \\
\hline Center......... & 1.4 & 47.0 & $A-2 \ldots \ldots$ & 1.0 & 44.0 \\
\hline$A-1 \ldots \ldots$ & 1.2 & 46.5 & $A-3 \ldots \ldots$ & .9 & 43.0 \\
\hline
\end{tabular}

B LINE.

\begin{tabular}{l|l|l||r|r|r|r}
\hline Center $\ldots \ldots \ldots \ldots \ldots \ldots$. & 1.4 & 47.0 & B-2 $\ldots \ldots \ldots \ldots \ldots \ldots$ & 1.1 & 47.0 \\
B-1 $\ldots \ldots \ldots \ldots \ldots \ldots \ldots$ & 1.2 & 48.0 & B $-3 \ldots \ldots \ldots \ldots \ldots \ldots$ & 1.0 & 44.0 \\
\hline
\end{tabular}

C LINE.

\begin{tabular}{|c|c|c|c|c|c|}
\hline Center $\ldots \ldots \ldots$ & 1.4 & 47.0 & $\mathrm{C}-3 \ldots \ldots$ & 0.9 & 44.0 \\
\hline $\mathrm{C}-1 \ldots$ & 1.3 & 48.0 & $C-4 \ldots \ldots \ldots \ldots \ldots$ & 1.0 & 44.0 \\
\hline $\mathrm{C}-2 \ldots \ldots \ldots$ & 1.2 & 45.0 & & & \\
\hline
\end{tabular}

D LINE.

\begin{tabular}{l|l|l||r|r|r}
\hline Center $\ldots \ldots \ldots \ldots \ldots \ldots .$. & 1.4 & 47.0 & $\mathrm{D}-2 \ldots \ldots \ldots \ldots \ldots \ldots$ & 1.0 & 44.0 \\
$\mathrm{D}-1 \ldots \ldots \ldots \ldots \ldots \ldots$ & 1.6 & 48.0 & & & \\
\hline
\end{tabular}

E LINE.

\begin{tabular}{|c|c|c|c|c|c|}
\hline Center $\ldots . . . . . . .$. & 1.4 & 47.0 & $\mathrm{E}-3 . \ldots \ldots$ & 0.8 & 45.0 \\
\hline E-1 $\ldots \ldots \ldots \ldots \ldots$ & 1.2 & 48.0 & $\mathrm{E}-4 \ldots \ldots \ldots$ & 1.0 & 45.0 \\
\hline $\mathrm{E}-2 \ldots$. & 1. 2 & 45.0 & & & \\
\hline
\end{tabular}


TABLE X.-Bouquet River sample series of August 21, 1904-Continued. SOUTH SHORE.

\begin{tabular}{|c|c|c|c|c|c|}
\hline Sampling point. & Chlorine. & $\begin{array}{l}\text { Alka- } \\
\text { linity. }\end{array}$ & Sampling point. & Chlorine. & $\begin{array}{l}\text { Alka- } \\
\text { linity. }\end{array}$ \\
\hline Center . . . . . . . . . & 1.4 & 47.0 & $3 \ldots$ & 3.5 & 54.0 \\
\hline $1 \ldots \ldots \ldots$ & 3.0 & 56.0 & $4 \ldots \ldots \ldots$ & 3.8 & 55.0 \\
\hline $2 \ldots \ldots \ldots \ldots$ & 3.3 & 54.0 & & & \\
\hline
\end{tabular}

NORTH SHORE.

\begin{tabular}{l|l|l||l|l|l}
\hline Center $\ldots \ldots \ldots \ldots \ldots \ldots \ldots$ & 1.4 & 47.0 & $3 \ldots \ldots \ldots \ldots \ldots \ldots \ldots \ldots$ & 1.0 & 47.0 \\
$1 \ldots \ldots \ldots \ldots \ldots \ldots \ldots \ldots$ & 1.0 & 47.0 & $4 \ldots \ldots \ldots \ldots \ldots \ldots \ldots$ & 1.2 & 45.0 \\
$2 \ldots \ldots \ldots \ldots \ldots \ldots \ldots \ldots$ & 2.1 & 60.0 & & & \\
\hline
\end{tabular}

The south shore samples, as might be expected, show a considerable concentration of the waste from the stream, the chlorides and the alkalinity being higher than at the center buoy. In fact, the condition of the water at the center buoy in the mouth of the river is remarkable in having an alkalinity not greater than that in the broad lake and an insignificant increase only in the amount of chlorine. There seems, however, to have been a concentration of the waste along the south shore during the same period at which, from one reason or another, the amount of waste running down the stream was greater than during the period at which the sample was taken. The reason for this was not shown in the investigation, as it was demonstrated that the amount of waste turned into the stream had been practically constant for several days previous. The most probable reason for the condition is the effect of the peculiar shore line and the wind.

The A line shows no evidence whatsoever of the presence of waste f rom the mill, nor does the $B$ line even at a distance of 1,000 feet from the center buoy and around the sand bar mentioned in the discussion of the sample series of August 12. In fact, the samples taken along the various lines as a whole give entirely negative evidence, proving conclusively that the effect of the wastes turned into Bouquet River is not appreciable for any considerable distance into the lake, and that the only apparent effect traceable is alongshore immediately north or south of the river's mouth.

The data afforded by the two sample series above discussed show unmistakably that while the sedimentation bed of the Willsboro mull is in operation, and while care is taken in the operation of the mill, there is no appreciable pollution of Lake Champlain from Bouquet River. In considering matters of this kind the inquiry is usually extended to two broad questions: (1) Whether the foreign matter turned into the stream is appreciable in the lake; and (2) if appreciable, 
whether or not its presence is deleterious. In this case, however, it is unnecessary to enter into the second part of the problem. So far as the specific material turned into the river by the mill is concerned it can not be traced by chemical means for any distance into the lake. It has been shown in previous pages that the pollution is a chemical rather than an organic one, and that the substances are lime, soda, and chlorine. It was further shown that the amount of lime even in the effluent from the sedimentation bed is extremely small, and that many lakes, rivers, and water supplies throughout the country contain far more without doing damage. It has been further shown that, as soda and ehlorine are the principal polluting constituents, the determinations of chlorine and of alkalinity are the specific determinations for use in the investigation of this class of pollution. The evidence of the sample series of August 12 and 21 demonstrates that no damage results in the lake. These conclusions are made with the reservation that the sedimentation bed at the Willsboro mill shall be in operation and shall work as effectively as it did during the period of the investigation.

Sample series of August 31.-It was believed wise, however, to determine what the effect might be if the sedimentation bed were not operated. This was made all the more desirable because of the oftrepeated statement by the complainants that, although by the introduction of the sedimentation bed the greater part of the ground for complaint against the mill had been removed, the bed had not been operated previous to the commencement of the investigation, and that typical results were not obtained by the author. Arrangements were therefore made with the mill authorities to disconnect the trough shown in Pl. II, $B$, which conducts the wastes across the stream and into the sedimentation bed, and to allow the raw material to run down the river and into the lake for a period of twenty-four hours, at the end of which samples were to be taken and a general series of determinations made to ascertain whether or not the conditions would be materially different from those in the case of the two previous sample series. Accordingly the trough was disconnected at $3.20 \mathrm{p.} \mathrm{m}$. on August 30, and the entire waste from the mill, including black-ash and lime sludges, was allowed to flow into the stream until 5 p. m. on August 31. At 4 p. m. on August 31 a series of samples was taken at the mouth of the river, at positions indicated on the map, Pl. VIII. A northeast wind, blowing at the rate of 10 miles an hour, was piling up the waves across the sampling field and diverting all the flow from the river southward along the shore of the lake.

It did not require chemical analysis to determine the effect of the discharge. From the mouth of the river around the point and south thereof, and thence along the shore in a dark purplish band about 300 feet in width, the mill waste extended down the south shore 
for a distance of about 1 mile. Here it ended and the water beyond was of the normal appearance. The results of the investigations in Table XI will show the character of the water.

TABuE XI.-Bouquet River sample series of August 31 and September 2, 1904. [Parts per million.]

A LINE. $a$

\begin{tabular}{|c|c|c|c|c|c|}
\hline Sampling point. & Chlorine. & $\begin{array}{l}\text { Alkalin- } \\
\text { ity. }\end{array}$ & Sampling point. & Chiorine. & $\begin{array}{l}\text { Alkalin- } \\
\text { ity. }\end{array}$ \\
\hline Center $\ldots \ldots \ldots \ldots$ & 9.8 & 59.0 & $A-2 \ldots \ldots \ldots \ldots . . .$. & 1.1 & 45.0 \\
\hline$A-1 \ldots \ldots \ldots$ & 1.1 & 45.0 & $A-3 \ldots \ldots$. & .9 & 45.0 \\
\hline
\end{tabular}

B LINE. $a$

\begin{tabular}{|c|c|c|c|c|c|}
\hline Center ................. & 9.8 & 59.0 & $B-2 \ldots \ldots \ldots \ldots$ & 6.2 & 57.0 \\
\hline B-1 $\ldots \ldots \ldots \ldots$ & 8.9 & 58.0 & B-3 .. & 1.1 & 45.0 \\
\hline
\end{tabular}

C LINE. $a$

\begin{tabular}{|c|c|c|c|c|c|}
\hline Center $\ldots \ldots \ldots \ldots$ & 9.8 & 59.0 & $\mathrm{C}-2 \ldots \ldots \ldots \ldots \ldots$ & 1.5 & 44.0 \\
\hline $\mathrm{C}-1 \ldots \ldots \ldots \ldots$ & 1.3 & 44.5 & & & \\
\hline
\end{tabular}

D LINE, $a$

\begin{tabular}{|c|c|c|c|c|c|}
\hline Center . . . . . . . . . . . & 9.8 & 59.0 & $\mathrm{D}-2 \ldots \ldots \ldots \ldots$ & .9 & 44. 0 \\
\hline$D-1 \ldots \ldots \ldots$ & 1. 2 & 45.0 & & & \\
\hline
\end{tabular}

SOUTH SHORE.a

\begin{tabular}{|c|c|c|c|c|c|}
\hline Center $\ldots \ldots \ldots \ldots$ & 9.8 & 59.0 & $5 \ldots \ldots \ldots \ldots \ldots$ & 1.9 & 46.0 \\
\hline $1 \ldots \ldots \ldots \ldots$ & 5.2 & 60.5 & $6 \ldots \ldots$ & 3.2 & 45.0 \\
\hline $2 \ldots \ldots \ldots \ldots \ldots$ & 7.2 & 54.0 & $7 \ldots \ldots \ldots . . . . . .$. & 1.4 & 44.0 \\
\hline $3 \ldots \ldots \ldots$ & 5.2 & 47.0 & $8 \ldots$ & 1. 3 & 45.0 \\
\hline $4 \ldots \ldots \ldots$ & 4.0 & 46.0 & $9 \ldots$. & 1.1 & 45.0 \\
\hline
\end{tabular}

SOUTH SHORE. $b$

\begin{tabular}{|c|c|c|c|c|c|}
\hline $1 \ldots \ldots \ldots \ldots$ & 7.5 & 53.0 & $5 \ldots \ldots \ldots \ldots \ldots$ & 1.3 & 45.0 \\
\hline $2 \ldots$ & 1.6 & 47.0 & $6 \ldots$. & 1.2 & 44.5 \\
\hline $3 \ldots \ldots \ldots \ldots$ & 1.6 & 44.5 & $7 \ldots \ldots \ldots$ & 1.1 & 45.0 \\
\hline 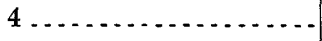 & 1.2 & 44. 0 & $8 \ldots \ldots \ldots$ & 1.0 & 45.0 \\
\hline
\end{tabular}

a August 31.

$b$ September 2.

It will be seen that at the center buoy there was a chlorine content of 9.8 parts per million, with an alkalinity of 59 . At the sampling points on the $A$ line, situated at $2,000,2,500$, and 3,000 feet from the 


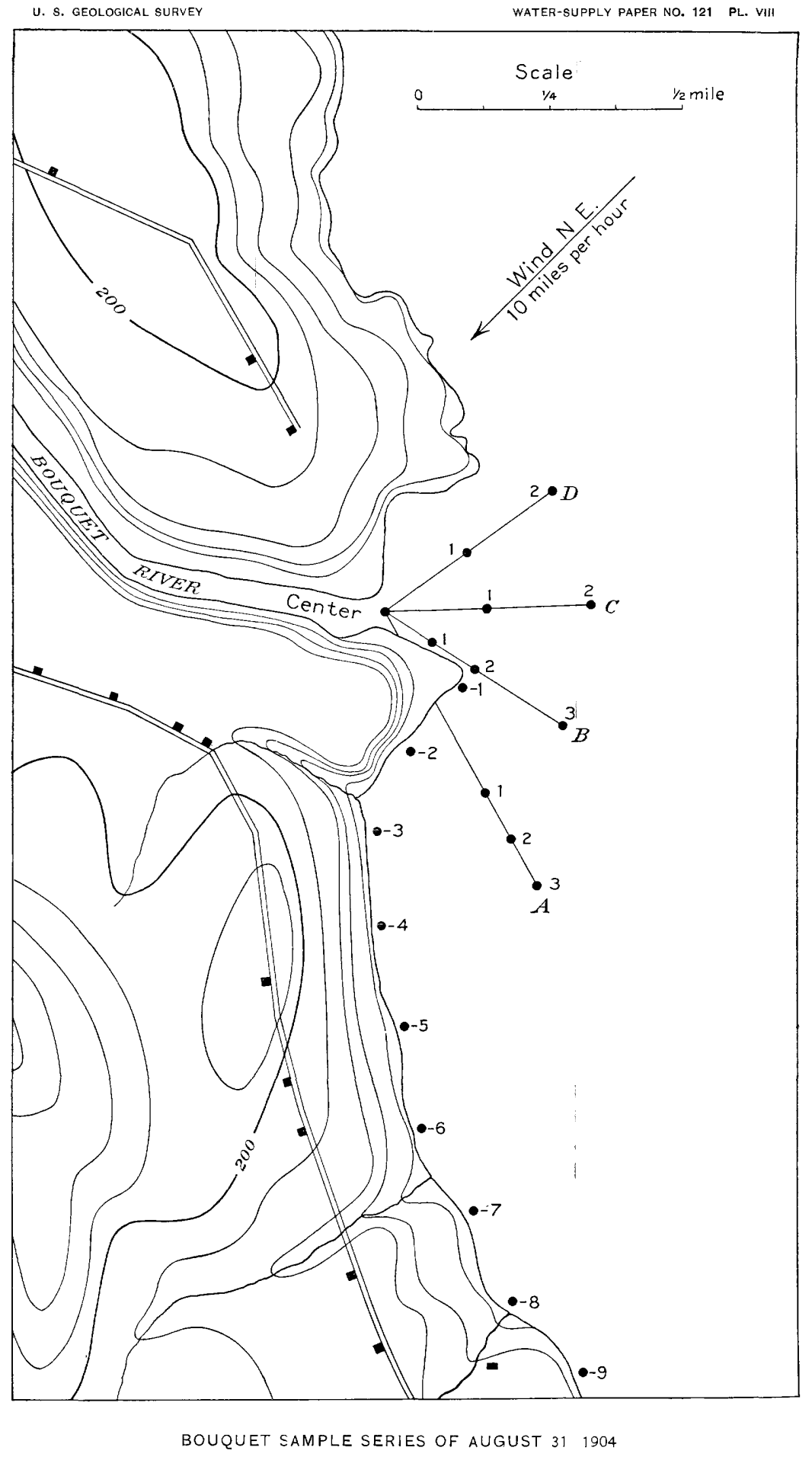


center and one-fifth to one-fourth mile from the shore, the chlorine and alkalinity were subnormal. Along the B line, at points 1 and 2, being 500 and 1,000 feet, respectively, from the center buoy and beyond the narrow line of influence of the waste, the water was normal. The samples along line $\mathrm{C}$ showed a slight rise in chlorine, but subnormal alkalinity, while no effect along line $\mathrm{D}$ was perceptible. Along the south shore line samples from points varying from about 800 to 1,000 feet apart show clearly the effect of the discharge of waste. Sample No. 9 was taken about 50 feet beyond the point at which the visible effect of the waste ended, and, as shown by the determination, is a normal lake water.

The evidence shown by the series of samples and by the observations made at the time of sampling indicates that when the waste is turned from the Willsboro mill directly into the stream the local effects about the mouth of the river are marked. In order to determine how long the condition which was brought about by this direct discharge might persist; a series of samples was taken along the shore two days later, on September 2, which are set forth in the last section of Table XI. They show conclusively that while the results of the discharge of water directly into the stream were not so marked as on August 31, the chlorine and alkalinity were higher than at any time during the previous examinations.

Conclusions.-It is apparent that the daily discharge of the entire amount of mill sludge directly into the stream would, if continued for a long period, affect the lake even more than is indicated by the shortterm discharge noted in the above discussion. The deposit of large quantities of lime along the bed of the stream would increase the damage already done there and would seriously affect the lake by reason of its being washed down into it at every freshet. From the results of the experimental discharge it can not be determined with any degree of assurance just what the effect would be, but it is reasonably safe to assume that the conditions for a considerable distance in the lake and to the north and south of the river's mouth would be comparable to those now existing in the stream.

The evidence given on the previous pages is, in the opinion of the author, unquestionably sufficient to support the opinion that the pulp mill at $\mathrm{W}$ illsboro has not the slightest harmful effect upon the lake when it is operated in connection with the sedimentation bed. While objection has been raised to the sedimentation bed itself, the statements made have been based upon features which are not necessary to the efficiency of the bed as a separator of suspended material, but rather upon features which should interest only the company maintaining the plant. It is not within the scope of this report to criticise the sedimentation bed or any device which has been set up to prevent the pollution of streams. Strictly, the investigation was limited 
to the lake itself, and the limit has been overstepped only when it was necessary to do so in order to intelligently lead up to a discussion of the real problems. Therefore, whatever may be said by way of criticism of the sedimentation bed must be left for other investigations and reports. It is sufficient to state that the plant which is now provided is efficient in caring for the suspended matter in the waste, and that what flows over the lower end of the retaining wall is not of a character to influence in the slightest degree the water of the lake beyond the short distance of from 1,000 to 2,000 feet from the river's mouth.

\section{AUSABLE RIVER.}

\section{ORIGIN AND COURSE.}

East and West branches of Ausable River join to form the main stream on the northern border of Jay Township. From this point the river flows northwestward to Lake Champlain, forming the boundary between Essex and Clinton counties. The distance between the confluence of the two branches and the mouth of the river is about 20 miles. West Branch of Ausable River rises in Lake Placid, at an elevation of 1,864 feet. East Branch rises in Ausable lakes, in the Adirondack Mountain Reserve, the elevation of the upper lake being 1,993 feet. The main stream enters Lake Champlain at an elevation of 101 feet. From this it may be seen that Ausable River is a fairly good power stream $(\mathrm{Pl} . \mathrm{V}, B)$, although the variable flow makes it somewhat unreliable in dry seasons. Nevertheless, the valley has attracted many industries (Pl. IX, $B$ ) and has been in the past of considerable importance as an iron-manufacturing center. At the junction of the two branches is the village of Ausable Forks, which was initially developed by the iron industry and later grew by the wood-pulp industry. Six miles below, at Clintonville, there was at one time a fair amount of activity in the iron industry, but this has during recent years failed completely, and the village presents a deserted appearance. Still farther down the stream is the village of Keeseville, a conservative old town, which has developed considerable importance in the past by reason of its various manufacturing plants.

Three miles below this the river enters what is known as Ausable Chasm, a striking feature of that part of the country. It is a very narrow gorge, about 100 feet in depth, and varying in width from 10 to 50 feet, with perpendicular walls. This chasm has been eroded by the stream through the Potsdam sandstone and is well represented in Pl. IV, $B$. Altogether, Ausable River is of considerable importance by reason of its useful and attractive features, and of late the country has been developed more and more extensively as a summer resort.

The river enters Lake Champlain about 3 miles north of Port Kent; the country at its mouth is very low and swampy and of delta-like 


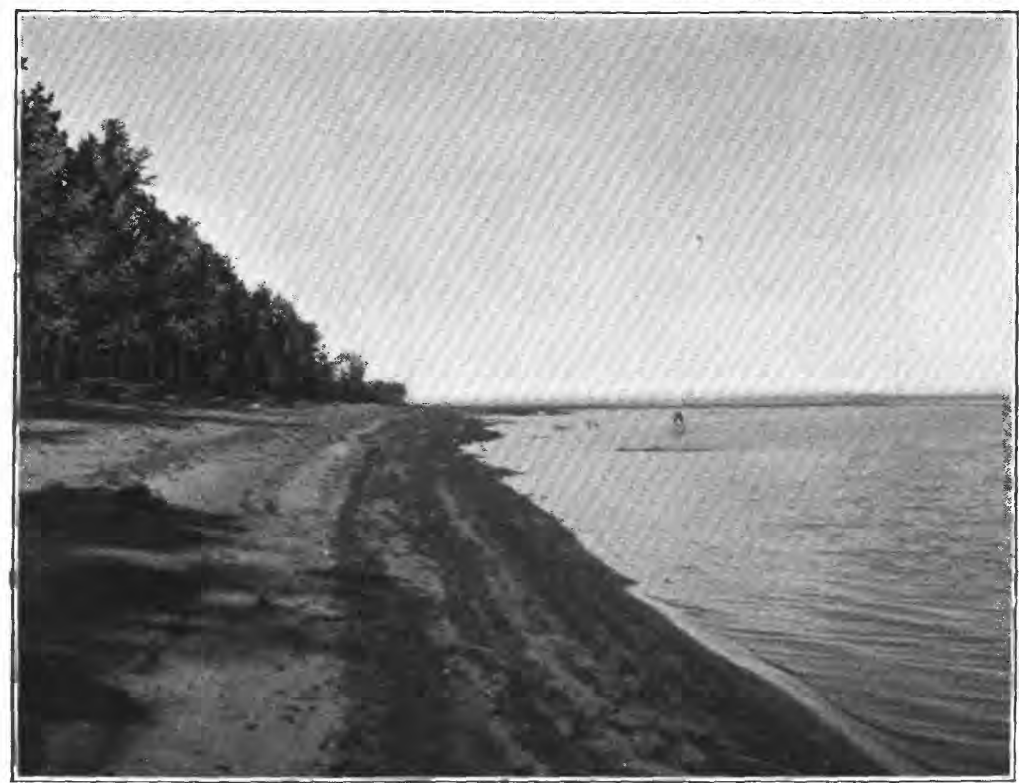

A. WOOD PULP AND SAWDUST ON WEST SHORE OF LAKE CHAMPLAIN.

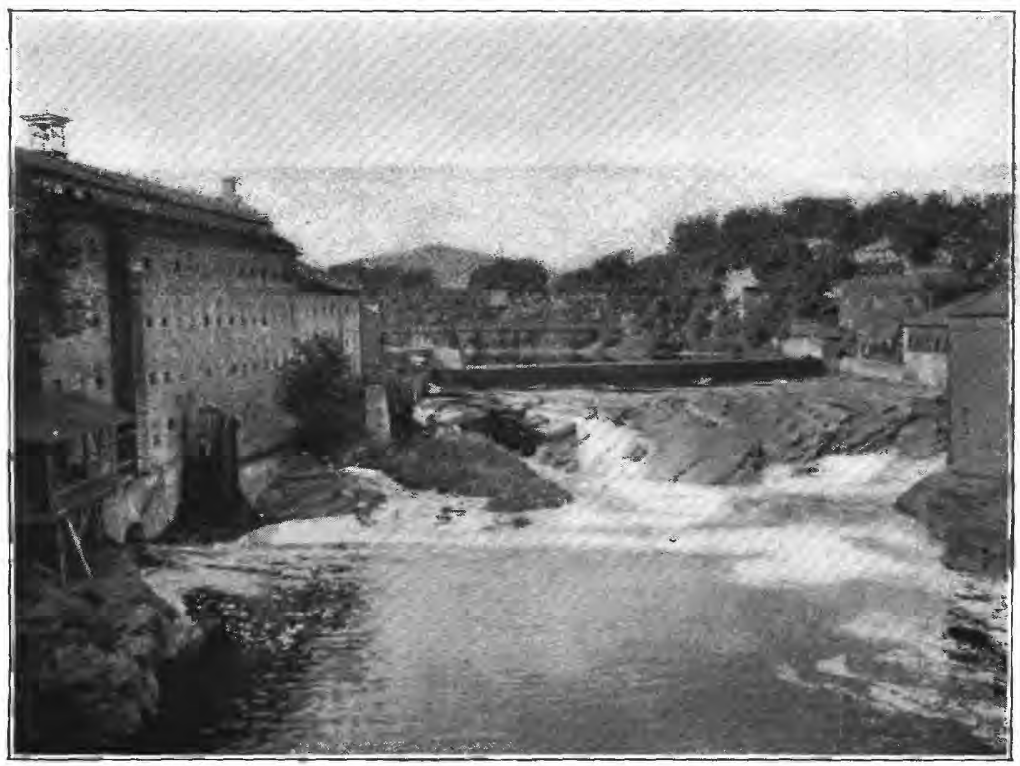

B. FALLS ON AUSABLE RIVER AT KEESEVILLE, N. Y. 
formation. At the present time the waters of the river enter the lake by two outlets, and formerly there were several others, a third having been closed by sedimentary deposits within recent years. (See map, Pl. I.)

\section{SULPHITE-PULP POLLUTION.}

The principal point of interest for the purposes of this report is at Ausable Forks, where there have been established the extensive pulp and paper mills of the J. \& J. Rogers Company. The process by which pulp is manufactured at this plant differs materially from that at Willsboro. The separation of the lignin and other extractives from the cellulose rests upon the action of sulphurous acid, which is applied to the wood in the form of an acid calcium sulphite. In order to determine the character of the waste from the sulphite process it will be necessary to review in some detail the manufacturing process. It is, on the whole, much simpler to describe and involves fewer appurtenant plants than the soda process, while at the same time the byproducts are far more complex and present difficulties which up to the present time have baffled the skill of the ablest chemists.

\section{MANUFACTURE OF SULPHITE-PULP.}

The manufacture of sulphite pulp differs from that of soda pulp in that the medium by which the wood is digested is an acid sulphite of calcium instead of a caustic soda. This substance is more effective in the disintegration of fiber than is caustic soda, and is therefore used upon tougher and more consolidated woods, notably spruce. In many respects the two processes are similar. The spruce wood used is barked and chipped in the same way, and the chips are turned into the digesters and treated with the liquor in a substantially similar manner.

ME'THODS OF MANUFACTURE.

The acid sulphite used to disintegrate the cellulose fibers is made in the following manner: Sulphur is burned in furnaces, the air supply of which is regulated, and the sulphur dioxide thus formed is carried over to a cooler, whence it is drawn through a series of three tanks filled with milk of lime. This is generally designated the "vacuum process." The gas is first drawn upward by virtue of a partial vacuum created in the tanks, through the lowest tank, where a part of the gas is absorbed; it is then carried to the next higher; finally it is absorbed by the milk of lime in the third tank. This operation is easily regulated by adjusting the supply of sulphurdioxide gas and the vacuum in the tanks. Under such a process the lowest tank has the strongest liquor. When it has reached a specific gravity of about $1.0357\left(5^{\circ}\right.$ Baumé, $7.14^{\circ}$ Twaddell $)$ it is drawn off IRR $121-05-4$ 
and the tank is again filled with the contents of the tank next above, which in turn is filled with the contents of the upper tank. The upper tank is then filled with fresh milk of lime. This process, while simple in its details, is, notwithstanding, somewhat troublesome, and requires careful supervision.

The digesters, filled with chips and liquor, are operated under 90 pounds pressure for about eight hours. In the mill of the J. \& J. Rogers Company there are 5 digesters. One of these, 44 feet high and 14 feet in diameter, holds 12 cords of chip wood and 12,000 gallons of sulphite liquor. The four others have one-half the abovestated capacity. The end point of the digestion process is regulated according to the acidity of the liquor; when this acidity has been reduced below a certain equivalent the digestion process is complete. A common method is to observe the odor of a sample of sulphite liquor drawn from the digesters. Although this is not an accurate and scientific test, it is an invaluable one and is readily applied by the operator. The odor which determines the end of the digestion is described as a "cooked odor."

When the digestion is complete the contents are blown into a pit, where the liquor is drained from the pulp. This liquor is entirely different from that turned into the digester at the beginning of the process. It has lost the greater part of its acid, a part going back into the reclaimers that are provided in connection with every series of digesters, and the remainder having become spent in the digestion process. When the liquor is turned into the digester it is 2.80 per cent acid; when the digestion is complete the liquor is barely acid, about 0.37 per cent, and this is diluted with several times its own amount of water in the washing process. After the pulp has drained it is washed with fresh water and sifted, washed again, separated from a part of its water, and then run upon the wet machines and made up in a manner somewhat similar to that already described in the case of soda pulp.

\section{WASTES OF MANUFACTURE.}

There arise in the process of sulphite-pulp manufacture two effluent liquors - the first consisting of the liquor drained from the newly made pulp and the wash water which is used upon it, and the second of the water used in connection with the screening and felting of the pulp. Both these liquors are wasted. It is the first, however, which claims attention, as it is composed largely of organic matter in the shape of wood extractives.

The spent digestion liquor, which is composed of "sulphenated lignone bisulphite compounds," is an extremely complex substance. It is slightly acid, reddish brown, and of gummy consistency. Although it contains valuable ingredients, all efforts toward recovery 
upon an economic and practical basis have failed, in spite of the fact that substantial rewards have been offered for a process. It is one of the most troublesome industrial wastes known, and its disposal has been a vexatious problem wherever pulp mills have been established. Up to the present time the best efforts of American and European chemists have failed to devise means for the recovery, or even the unobjectionable disposal, of sulphite-pulp wastes, and in many cases, notably in Germany, where the laws against stream pollution have been strictly enforced, several sulphite-pulp mills have been closed down by the imperial authorities.

Samples of the sulphite liquor taken from the digesters at the end of the digestion process at the Rogers mill were found to contain $10 \frac{1}{2}$ per cent of solid material. About 90 per cent of this residue consisted of organic and volatile matters, while about 5.7 per cent consisted of calcium sulphate. The liquor has a distinctly acid reaction. It is run from the digesters into the blow pits, where it is diluted to several times its volume in the washing process; as it emerges from the mill and is discharged into the river it is still acid and contains 0.42 per cent of calcium sulphate, the remainder of the liquor being largely lignin and other organic extractives.

As the liquor is discharged into the stream it is of a bright reddishbrown color, and contains a considerable proportion of fine wood pulp which has passed through the sieves.

\section{EFFECT OF SULPHITE-PULP WASTES.}

EFFECT ON AUSABLE RIVER.

It is of interest to compare the process at this point with that already described in the case of soda-pulp manufacture. The liquor from the wash pan at the soda-pulp mills is turned into the soda-recovery process, and the organic matter and waste cellulose are burned in the furnaces. In the sulphite process, on the other hand, there being no method of recovery, the waste pulp and organic matter are turned directly into the stream. Therefore it appears at the outset that the waste from this process is largely an organic one. Examination of the stream below the point of entrance of the waste verifies this statement. Almost immediately the waste changes from reddish brown to a black or very dark-purple color, and considerable putrefaction takes place, the odor along the banks of the stream resembling burnt rubber. The bed of the stream, too, at points of slack water is covered with waste pulp, and the whole river along the 20 miles intervening between Ausable Forks and the lake is inky black and generally unattractive in appearance.

The village of Keeseville takes its water supply from Ausable River at a point well within the limits of the village. Considerable 
complaint has been made by the residents of this village because of the undesirable appearance and alleged unhealthfulness of the stream. Undoubtedly there is considerable damage done to the water supply of Keeseville, but under the present conditions there is no doubt that the pulp-mill waste is a benefit to the town. While complaining against the Rogers pulp mill the village has neglected to keep its own skirts clean; at several points above the intake of the waterworks there are private sewers of the most dangerous sort entering the river, and the conditions favoring an extensive typhoid epidemic are ideal. There has, however, been little typhoid fever in Keeseville, because the appearance and odor of the water are so bad that none of the citizens use it for drinking purposes. If it had retained its original appearance-that is, if the sulphite-mill waste had been kept out of the stream - the water would have been used by the majority of the inhabitants, with the fatal results which have been witnessed in so many other American municipalities. Therefore the condition of Ausable River as a result of pulp-mill waste, bad as it undoubtedly is, is an important measure of safety for the people of Keeseville, and before that community can with any propriety take up cudgels against the pulp mill it will be necessary for them to place their own surroundings above suspicion.

Two miles below Ausable Forks a partial analysis was made of Ausable River water. It contained 185.8 parts per million of total solids, of which 119 parts were organic and volatile matter. Strange to say, the amount of calcium was only 13.54 parts, somewhat less than that in the Lake Champlain water. The river, too, had neutralized the acid contributed to it by the sulphite waste. The alkalinity in terms of calcium carbonate amounted to 27 parts per million, considerably less than that of the water of Lake Champlain, and the same as the alkalinity of the water of West Branch above all points of pollution. It is evident, then, that although the principal chemical turned into the stream from the sulphite mill is calcium sulphite, this determination can not be resorted to in tracing the waste into Lake Champlain; for, as was shown above, 2 miles below the point of entrance of the waste the amount of calcium is less than that in the lake. Hence it is apparent that the specific determinations which will most readily distinguish the water of the river from that of the lake are those which will reveal the increase in organic matter. The excess of alkalinity of the water of the lake over that of the river also promises to furnish valuable evidence. These two determinations were therefore selected as specific, and results show that the selection was justified.

Analysis shows that there is no doubt whatever concerning the damaging effect of the waste upon the river. Whether or not this extends into the lake remains to be seen. 
EFFECT OF SULPHITE-PULP WASTES ON LAKE CHAMPLAIN.

Ausable River discharges into Lake Champlain over an elevated bench which, even at high water, is only a few feet below the surface. Examination of this bottom and of the shores for several miles north and south of the two mouths of the river shows an enormous accumu lation of wood pulp, together with a greater accumulation of sawdust, which is turned into the stream from the many sawmills in the valley (Pl. IX, A). The shallow water lying over the bench carries large amounts of pulp in suspension, and is exceedingly malodorous by reason of its large content of putrescible organic matter.

Methods of investigation. - The investigation was planned along lines somewhat similar to those followed for Bouquet River. Samples were taken in the upper and lower mouths of the river, and from these at intervals along divergent lines running north, south, and east. The various modifying features which prevailed in the case of the Bouquet investigations apply here, especially the effect of the winds blowing at the time of sampling. If the specific determinations decided upon in this investigation are well chosen, we may expect to find that the percentage of volatile solids in the water of the lake will decrease in the progressive samples from the central points, while, on the other hand, the alkalinity of the water (which is greatly reduced by reason of the pouring of the acid water into the river) may be expected to increase as the unpolluted waters of the lake are approached. This will be brought out in detail in the following discussion of the various sample series.

Sample series of August 23.-The samples in this series were distributed along four lines, two running from a center situated at the north mouth of the Ausable and two from a center similarly situated at the south mouth (fig. 1, p. 54). Line D, from the north center, runs almost due east for about 1,500 feet, and then turns northward with a divergence of about $15^{\circ}$ east. Sample No. 1 was taken at the bend in line $\mathrm{D}$, while samples Nos. 2,3 , and 4 were taken at 1,500 , 6,000 , and 11,000 feet, respectively, along the D line from No. 1. Line C was run east by about $10^{\circ}$ south, and samples Nos. 1, 2, and 3 were taken at $1,000,2,500$, and 4,500 feet, respectively, from the center. Line $\mathrm{B}$ was run from the south center east by about $5^{\circ}$ south, and samples were taken at approximately the same intervals as along line C. Line $A$ was run from the south center direct toward Trembleau Point, and thence to the north end of Schuyler Island and around to the south end. Samples were taken along this line as follows: No. 1, 1,000 feet from center; No. 2, 2,500 feet; No. 3, 5,000 feet; No. 4, 8,500 feet; No. 5, 13,000 feet; No. 6, 17,000 feet; No. 7, 20,000 feet; No. 8, 23,000 feet; No. 9, 28,000 feet. Lines $A$ and $D$ were run so much farther from the center on account of the currents in the lake, described on page 18. The prevailing winds for a considerable period 
previous to the day of sampling had been either north or south; in fact, during the twenty-four hours previous to the sampling the wind had been blowing from the north at an average rate for the entire period

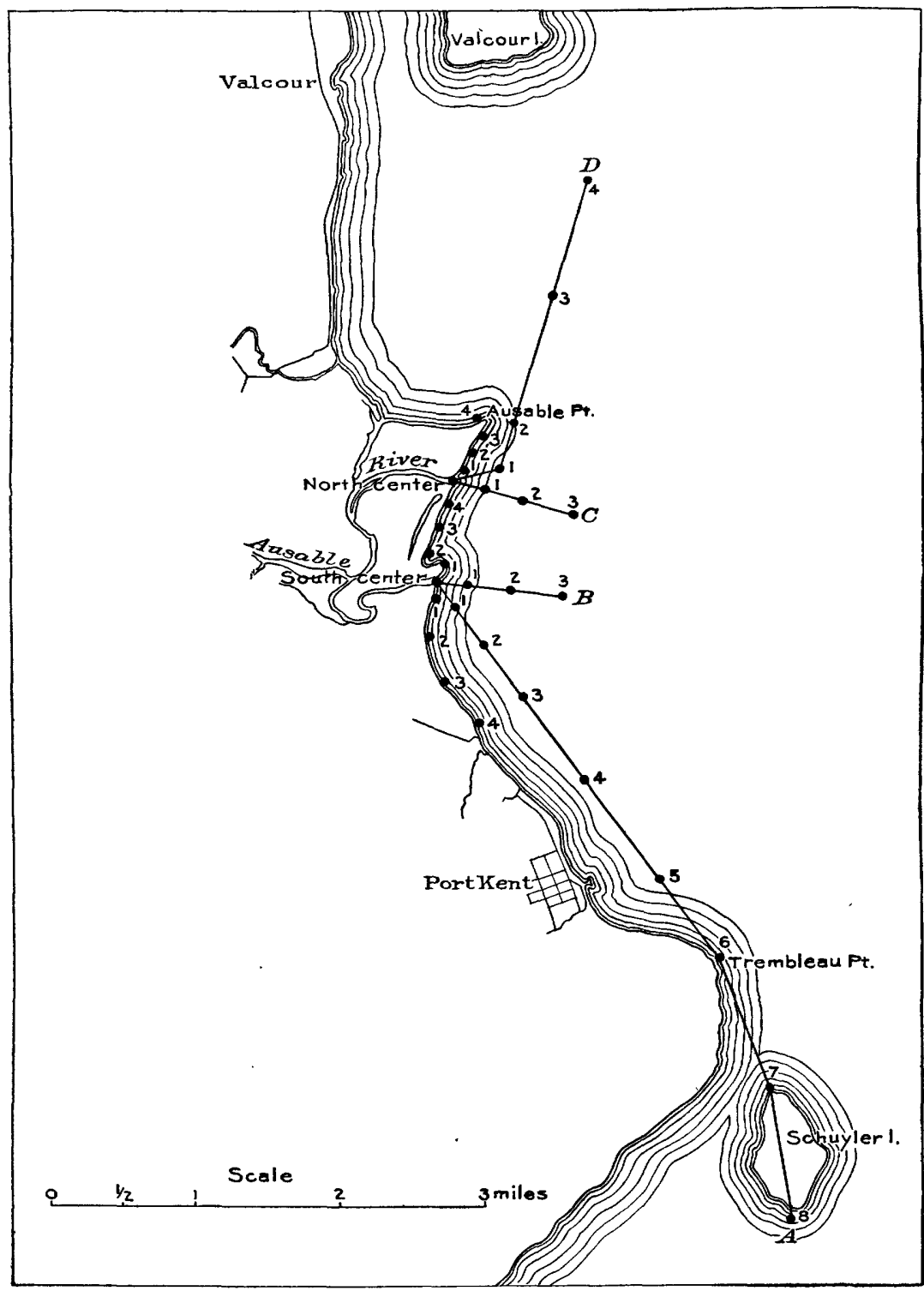

FIG. 1.-Ausable sample series of August 23, 1904.

of 11 miles an hour, reaching a maximum of 21 miles an hour. At the time of sampling, however, this wind had died away and the lake was flat. 
Table XII sets forth the results of the determinations made upon the samples. For purposes of comparison the standards set forth in Table III will be restated, as follows: Total solids, 65.6 ; volatile solids, 21.8; per cent volatile, 32.8; alkalinity, 47. It is readily apparent that a comparison between the actual amount of total solids in each of the samples, as well as the actual amount of volatile solids, does not give as comprehensive information as the statement of the per cent of volatile solids. This, then, is the determining factor so far as solids are concerned.

TABLE XII.-Ausable sample series of August 29, 1904.

[Parts per million.]

D LINE.

\begin{tabular}{|c|c|c|c|c|}
\hline Sampling point. & $\begin{array}{l}\text { Total } \\
\text { solids. }\end{array}$ & $\begin{array}{l}\text { Volatile } \\
\text { solids. }\end{array}$ & $\begin{array}{l}\text { Per cent } \\
\text { volatile. }\end{array}$ & $\begin{array}{c}\text { Alkalin- } \\
\text { ity. }\end{array}$ \\
\hline North center ... & 102.0 & 64.2 & 62.7 & 14.5 \\
\hline$D-1 \ldots \ldots$ & 80.8 & 39.0 & 48.3 & 37.0 \\
\hline D-2 $\ldots \ldots \ldots$ & 66.2 & 24.8 & 37.46 & 44.0 \\
\hline D-3. & 69.0 & 33.2 & 48.12 & 44.0 \\
\hline $\mathrm{D}-4$ & 65.0 & 32.0 & 49.25 & 44.0 \\
\hline
\end{tabular}

C LINE.

\begin{tabular}{|c|c|c|c|c|}
\hline 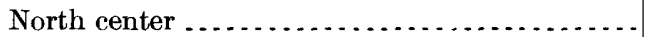 & 102.0 & 64,2 & 62.7 & 14.5 \\
\hline $\mathrm{C}-1 \ldots \ldots \ldots \ldots \ldots \ldots \ldots \ldots \ldots \ldots \ldots$ & 71.8 & 34.2 & 47.35 & 40.0 \\
\hline 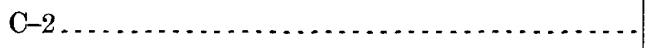 & 65.4 & 28.6 & 43.73 & 44.0 \\
\hline $\mathrm{C}-3 \ldots \ldots \ldots \ldots \ldots \ldots$ & 68.0 & 32.6 & 47.94 & 44. 0 \\
\hline
\end{tabular}

B LINE.

\begin{tabular}{|c|c|c|c|c|}
\hline South center $\ldots \ldots \ldots \ldots \ldots \ldots \ldots \ldots$ & 77.8 & 43. 0 & 55.27 & 14.0 \\
\hline 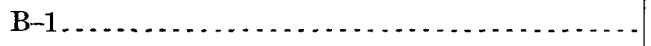 & 76.0 & 40.0 & 52.63 & 31.0 \\
\hline B-2..... & 64.8 & 29.2 & 45.06 & 44.0 \\
\hline $\mathrm{B}-3 \ldots \ldots \ldots \ldots \ldots \ldots \ldots \ldots \ldots \ldots$ & 64.0 & 28.2 & 44.06 & 44. 0 \\
\hline
\end{tabular}

A LINE.

South center

A-1.

A-2.

A-3.

A-4.

A-5.

A-6.

A-7.

A-8.

\begin{tabular}{l|l|l|l}
\hline 77.8 & 43.0 & 55.27 & 14.0 \\
78.0 & 42.6 & 54.61 & 20.0 \\
64.4 & 28.4 & 44.09 & 44.0 \\
66.0 & 26.8 & 40.61 & 35.0 \\
67.4 & 32.0 & 47.48 & 38.0 \\
66.6 & 29.6 & 44.44 & 43.0 \\
63.8 & 29.8 & 46.71 & 43.5 \\
64.8 & 26.8 & 41.36 & 44.5 \\
64.0 & 29.4 & 45.94 & 44.5 \\
\hline
\end{tabular}


TABLE XII.-Ausable sample series of August 23, 1904-Continued.

NORTH SHORE.

\begin{tabular}{|c|c|c|c|c|}
\hline Sampling point. & $\begin{array}{l}\text { Total } \\
\text { solids. }\end{array}$ & $\begin{array}{l}\text { Volatile } \\
\text { solids. }\end{array}$ & $\begin{array}{l}\text { Per cent } \\
\text { volatile. }\end{array}$ & $\begin{array}{c}\text { Alkalin- } \\
\text { ity. }\end{array}$ \\
\hline North center ..... & 102.0 & 64.2 & 62.7 & 14.5 \\
\hline $1 \ldots$ & 97.6 & 49.8 & 51.03 & .28 .0 \\
\hline $2 \ldots$ & 85.6 & 43.4 & 51.17 & 38.0 \\
\hline $3 \ldots \ldots \ldots \ldots \ldots$ & 82.0 & 40.0 & 48.77 & 39.5 \\
\hline $4 \ldots \ldots$ & 72.6 & 37.6 & 51. 79 & 41.5 \\
\hline
\end{tabular}

MID SHORE.

\begin{tabular}{|c|c|c|c|c|}
\hline North center $\ldots . \ldots \ldots \ldots \ldots \ldots$ & 102.0 & 64.2 & 62.7 & 14.5 \\
\hline $1, \ldots \ldots \ldots$ & 79.6 & 45.6 & 57.28 & 20.5 \\
\hline $2 \ldots \ldots \ldots \ldots$ & 70.4 & 32.4 & 44. 44 & 34.0 \\
\hline $3 \ldots \ldots \ldots \ldots \ldots \ldots \ldots$, & 85.0 & 47.0 & 55.29 & 20.5 \\
\hline $4 \ldots \ldots \ldots$ & 77.0 & 43.4 & 56.22 & 19.0 \\
\hline South center $\ldots \ldots \ldots \ldots$ & 77.8 & 43.0 & 55.27 & 14.0 \\
\hline
\end{tabular}

SOUTH SHORE.

\begin{tabular}{|c|c|c|c|c|}
\hline South center ..................... & 77.8 & 43.0 & 55.27 & 14. 0 \\
\hline $1 \ldots n_{1}$ & 71.6 & 38.6 & 53.91 & 15.0 \\
\hline $2 \ldots \ldots \ldots \ldots \ldots$ & 77.4 & 37.8 & 48.84 & 27.0 \\
\hline $3 \ldots \ldots+\ldots, \ldots$ & 70.0 & 33.8 & 48.29 & 36.5 \\
\hline $4 \ldots \ldots \ldots$ & 66. 6 & 29.6 & 44.4 & 47.0 \\
\hline
\end{tabular}

Considering now the $\mathrm{D}$ line, it will be seen that although the outermost sample was more than 2 miles distant from the river's mouth, the sampling was not carried sufficiently far to reach the point of normal lake water, the farthermost sample taken containing 49.25 per cent of volatile solids and 44 parts per million of alkalinity. The same is true of lines B and C. It is evident from this that the influence of the wastes from Ausable River extends out into the lake for a greater distance than 4,500 feet. The samples taken along the shore are also in excess of the normal per cent of volatile solids. In the farthermost sample of the south shore the alkalinity is normal. The most remarkable line of samples in the series 1 s the $A$ line, in which it is shown that the southward current along the west shore of the lake carries the high amount of solids down beyond the south end of Schuyler Island, a distance of $5 \frac{1}{3}$ miles, while at that point the alkalinity has not yet been raised to the normal.

Sample series of September 2.-This series of samples was taken under conditions and at points similar to those in the series of August 
23 (fig. 2). The D line, running from the north center, was split at buoy 6 east of Ausable Point, one leg running north and another east. The $\mathrm{C}$ and $\mathrm{B}$ lines were the same as in the previous series, while the $\mathrm{A}$ line was the same in direction but marked one less sample on

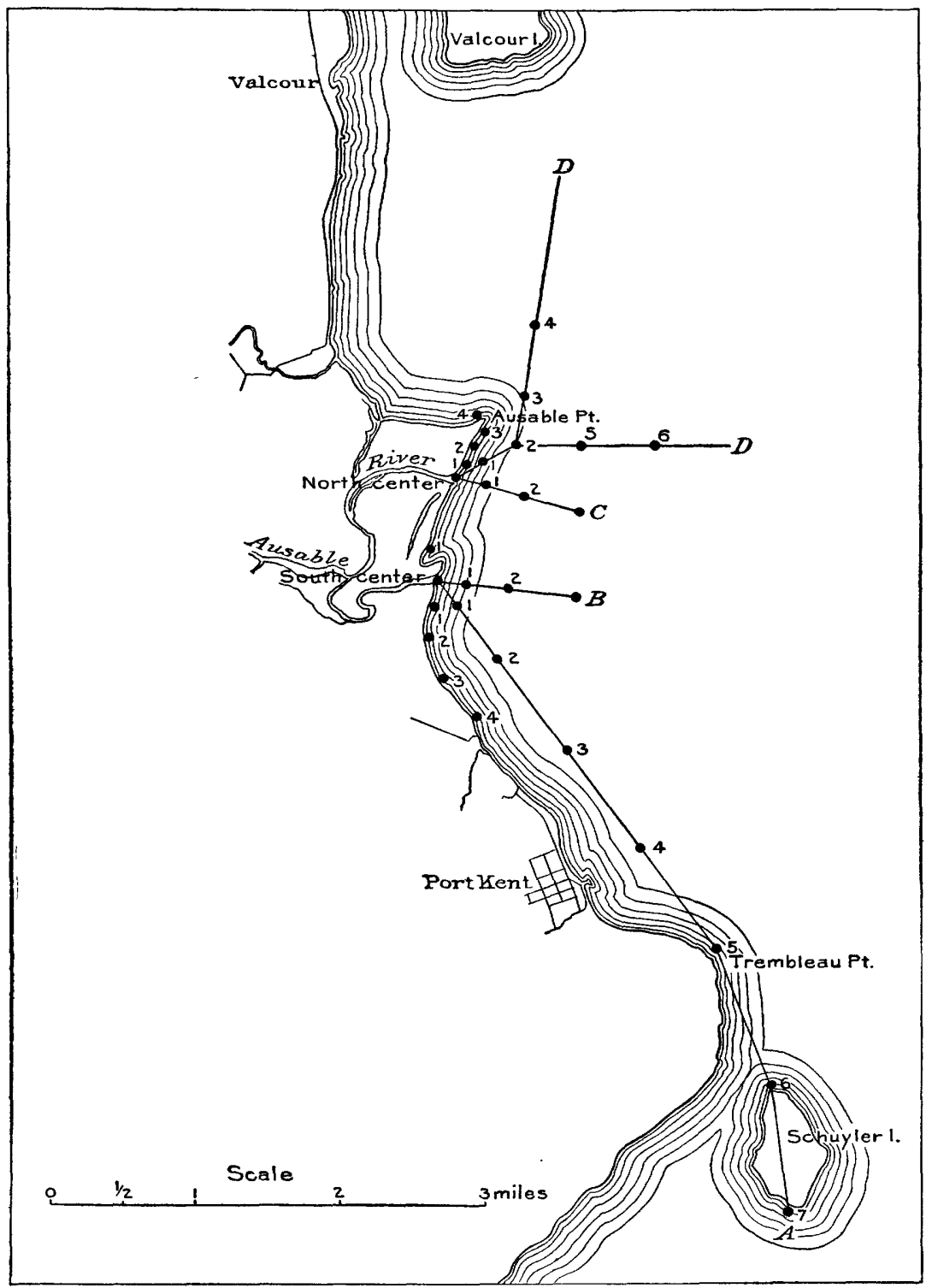

FIG. 2.-Ausable sample series of September 2, 1904.

the stretch between the south center and Trembleau Point. The wind during the twenty-four hours previous to the time of sampling had been blowing lightly from the north, and can hardly be considered an important factor in connection with the results. 
Table XIII.-Ausable sample series of September 2, 1904.

[Parts per million.]

D LINE.

\begin{tabular}{|c|c|c|c|c|}
\hline Sampling point. & $\begin{array}{l}\text { Total } \\
\text { solids. }\end{array}$ & $\begin{array}{l}\text { Volatile } \\
\text { solids. }\end{array}$ & $\begin{array}{l}\text { Per cent } \\
\text { volatile. }\end{array}$ & $\begin{array}{c}\text { Alkalin- } \\
\text { ity. }\end{array}$ \\
\hline North center .... & 162.2 & 103.2 & 63.6 & 29.5 \\
\hline D.1......... & 64.8 & 30.0 & 46.1 & 43.0 \\
\hline D-2... & 65.2 & 32.2 & 49.4 & 43.5 \\
\hline D $-3 \ldots \ldots$ & 64.8 & 34.0 & 52.5 & 43.0 \\
\hline $\mathrm{D}-4 \ldots \ldots \ldots$ & 70.0 & 31.6 & 45.1 & 44.0 \\
\hline D-5........ & 64.8 & 30.2 & 46.6 & 43.0 \\
\hline$D-6 \ldots \ldots$ & 66.8 & 28.6 & 42.8 & 43.0 \\
\hline
\end{tabular}

C LINE.

\begin{tabular}{|c|c|c|c|c|}
\hline North center $\ldots \ldots \ldots \ldots \ldots \ldots \ldots \ldots \ldots \ldots \ldots$ & 162.2 & 103.2 & 63.6 & 29.5 \\
\hline$C-1 \ldots \ldots \ldots \ldots$ & 68. 6 & 34.0 & $49: 6$ & 42.0 \\
\hline$c-2 \ldots$ & 67.4 & 30.2 & 44.8 & 43.0 \\
\hline $0-3 \ldots \ldots \ldots \ldots \ldots$ & 68.4 & 30.6 & 44.7 & 44.5 \\
\hline
\end{tabular}

B LINE.

\begin{tabular}{|c|c|c|c|c|}
\hline S Juth center $\ldots \ldots \ldots \ldots \ldots \ldots \ldots \ldots$ & 163.0 & 106.0 & 65.0 & 29.0 \\
\hline B-1... & 69.0 & 29.4 & 42.0 & 43.5 \\
\hline $\mathrm{k}-2 \ldots$ & 68.0 & 26.8 & 39.4 & 44.0 \\
\hline $13-3 \ldots$ & 62.0 & 26.6 & 42.9 & 44.0 \\
\hline
\end{tabular}

A LINE.

\begin{tabular}{|c|c|c|c|c|}
\hline South center $\ldots \ldots \ldots \ldots \ldots \ldots \ldots \ldots \ldots \ldots$ & 163.0 & 106.0 & 65.0 & 29.0 \\
\hline$A-1 \ldots \ldots$. & 66. 0 & 24.4 & 37.0 & 43.5 \\
\hline A-2... & 68.0 & 28.6 & 42.1 & 44.0 \\
\hline$\Lambda-3$. & 71.4 & 29.8 & 41.7 & 44.0 \\
\hline$A-4 \ldots$ & 73.8 & 30.4 & 41.2 & 44.0 \\
\hline$A-5 . .$. & 79.6 & 34.0 & 41. 7 & 44.0 \\
\hline $\mathrm{A}-6, \ldots \ldots \ldots, \ldots$ & 66.6 & 28.0 & 42.0 & 44.5 \\
\hline A $-7, \ldots \ldots \ldots$ & 68.6 & 30.0 & 43.7 & 45.0 \\
\hline
\end{tabular}

NORTH SHORE.

\begin{tabular}{|c|c|c|c|c|}
\hline North center $\ldots \ldots \ldots \ldots \ldots \ldots \ldots$ & 162.2 & 103.2 & 63.6 & 29.5 \\
\hline $1 \ldots \ldots,{ }_{1}$ & 107.2 & 59.4 & 55.4 & 36.0 \\
\hline 2 & 68.6 & 29.4 & 42.8 & 42.0 \\
\hline & 87.4 & 45.4 & 51.9 & 40.0 \\
\hline $4 \ldots \ldots \ldots \ldots \ldots$ & 97.6 & 53.2 & 54.6 & 36.0 \\
\hline
\end{tabular}


TABLE XIII.-Aúsable sample series of September 2, 1904-Continued.

MID SHORE.

\begin{tabular}{|c|c|c|c|c|}
\hline Sampling point. & $\begin{array}{l}\text { Total } \\
\text { solids. }\end{array}$ & $\begin{array}{l}\text { Volatile } \\
\text { solids. }\end{array}$ & $\begin{array}{l}\text { Per cent } \\
\text { volatile. }\end{array}$ & $\begin{array}{c}\text { Alkalin- } \\
\text { ity. }\end{array}$ \\
\hline North center ... & 162.2 & 103.2 & 63.6 & 29.5 \\
\hline $1 \ldots$ & 109.2 & 61.2 & 56.0 & 34.0 \\
\hline $2 \ldots$ & 120.0 & 73.6 & 61.3 & 32.5 \\
\hline South center $\ldots \ldots \ldots \ldots \ldots \ldots \ldots \ldots$ & 163.0 & 106.0 & 65.0 & 29.0 \\
\hline
\end{tabular}

SOUTH SHORE.

\begin{tabular}{|c|c|c|c|c|}
\hline South center $\ldots \ldots \ldots \ldots \ldots \ldots$ & 163.0 & 106.0 & 65.0 & 29.0 \\
\hline & 92.2 & 50.0 & 54.2 & 40.0 \\
\hline $2 \ldots$ & 69.6 & 32.2 & 46.3 & 42.0 \\
\hline $3 \ldots$. & 67.4 & 32.0 & 47.5 & 43.0 \\
\hline 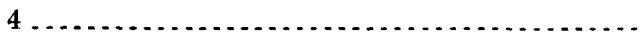 & 66.6 & 31.0 & 46.5 & 43. 0 \\
\hline
\end{tabular}

It will be seen, on examination of the above series, that the total solids in the water at the north and south centers are extremely large in amount and that from 63 to 65 per cent are volatile. The extremely low alkalinity is also an important factor. Considering first the shore samples, it will be noted that as far as they extend there are unmistakable evidences of pollution from Ausable River. The shore samples taken farthest from the two centers give marked evidence of contamination, and return to normal conditions may not be expected for a considerable distance farther than the outermost sampling points. The course taken by $\mathrm{D}$ line of samples, shown in fig. 2 , is well directed to illustrate the divergence in the directions along which foreign matter discharged upon the shores of the lake may be felt. Sample 2, on line $\mathrm{D}$, taken at the buoy, shows a percentage of volatile solids of 49.4 and an alkalinity of 43.5. At point 3 there is a slight rise in the percentage of volatile solids and a slight reduction in alkalinity, while at point 4 there is an unmistakable trend toward the normal characteristics of the lake water. How far it would be necessary to pursue this line in order to reach the normal lake is uncertain. Samples 5 and 6 , on $\mathrm{D}$ line, extending east from point 2 toward the broad lake, show a greater reduction in percentage of volatile solids in the same distance from the center than does the line running to the north.

The results along the $B$ and $C$ lines are similar to those in the previous series. They show simply that at a distance of nearly a mile directly into the lake from the two mouths of the river there is still a marked effect upon the water and that the normal characteristics are not yet recovered. 
The A line offers further evidence with reference to the pollution from Ausable River. It will be seen, on examination of the figures, that there is some irregularity in the results of the determination of total and volatile solids and that the reduction in the percentage of volatile solids is not so steady as might be expected. In fact, it is greater 5 miles away from the south center than at a distance of 1,000 feet from it. This is an anomalous result, due undoubtedly to the effects of the wind or local currents which had carried the organic matter along an irregular course on the day previous to that of taking this series of samples. The amount of alkalinity, however, shows a steady increase from the mouth of the river to the end of the $A$ line, and gives in this case the most important testimony concerning the effect of the sulphite waste.

In the two Ausable sample series, reviewed in previous pages, no attempt was made to trace out the limit of influence of the water of Ausable River upon the lake. This was not done because it was believed that if it were shown that the limit of influence is less than a mile the studies subsequently to be made would determine this limit with preciseness, while on the other hand if the matter from the river could be traced for a greater distance it was held that the exact limit was not important, inasmuch as the effect upon the lake would be sufficiently widespread and sufficiently serious to render further investigation unnecessary. The first two series did show, however, that although the samples along the $\mathrm{B}$ and $\mathrm{C}$ lines did not at the outer points represent the normal lake water, they approached sufficiently near it to show that such a condition might be attained within a reasonable distance. Along the A line, however, it has been shown that the effect of the waste persists for extraordinary distances. The southern trend of the current in the lake along both shores has already been remarked, and the determination of the extreme limit of the effect of the sulphite waste, which in this case is plainly due to the southerly current, is important.

Sample series of September 17.-A series of samples covering the points shown in fig. 3 was determined on and the samples were taken September 17. As will be seen, the central point for this series is taken at a distance of about one-fourth of a mile from the west shore, at a point about midway between the two mouths of the river. From this center the A line extends over practically the same course covered in the two previous series, but is carried on from the south end of Schuyler Island down into Willsboro Bay, to a point opposite Frisbies Point. The B line extends from the center toward Colchester Shoal, a distance of about $1 \frac{1}{2}$ miles into the broad lake.

Considering first the results of determinations of the samples taken along the $\mathbf{A}$ line, it will be seen that they are somewhat irregular and apparently do not follow the logical trend taken by the samples along 
this line in the two previous series. Sample 10, for example, has an alkalinity which is practically normal and presents only a small amount of volatile solids in excess of the observed normal amount for the lake; sample 9 , taken well up toward the mouth of the bay, contains practically the same amount of alkalinity, but a considerably larger proportion of volatile solids, while sample 8 , opposite the end of Willsboro Point, appears to differ from the normal lake water only in the high proportion of volatile solids. This may also be said of sample 7 , which was taken at a distance of nearly 1 mile from the New York shore, well out into the lake and nearly north of $W$ illsboro Point, where a thorough admixture of the waters of the broad lake with any local drainage might be expected. Sample 6, taken south of Schuyler Island in the broad reaches of Corlear Bay, shows results which are nearly normal, while sample 5 , taken on the southern shore of Schuyler Island, again indicates considerable organic pollution. Sample 4, taken from the north side, bowever, indicates a nearly normal water, while sample 3 , from Trembleau Point, is again indicative of the sulphite waste from Ausable River. Samples 1 and 2 contain the usual amount of pollution. Sample 2 is lower in its proportion of volatile solids than in the previous series of samples.

The $\mathrm{B}$ line, which extends into

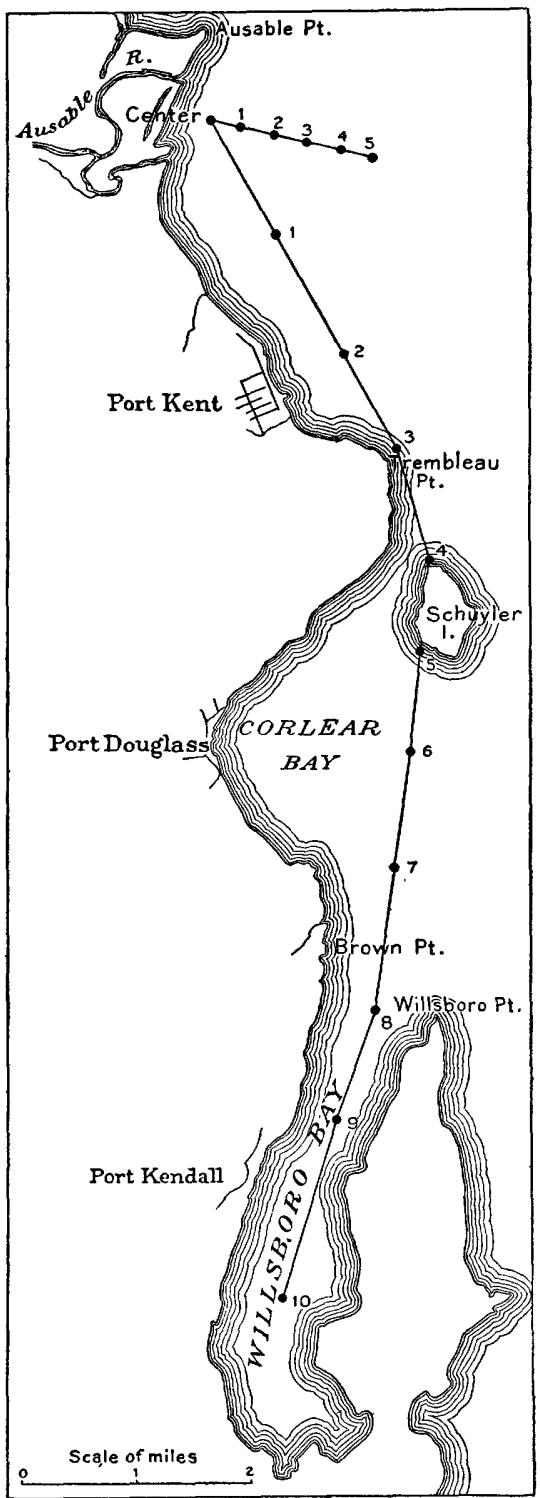

FIG. 3.-Ausable sample series of September 17,1904 . the lake a distance of about $1 \frac{1}{2}$ miles, along which were taken five sumples, affords results of interest. 
Table XIV.-Ausable sample series of September 17, 1904.

A LINE.

\begin{tabular}{|c|c|c|c|c|}
\hline Sampling point. & $\begin{array}{l}\text { Total } \\
\text { solids. }\end{array}$ & $\begin{array}{l}\text { Volatile } \\
\text { solids. }\end{array}$ & $\begin{array}{l}\text { Per cent } \\
\text { volatile. }\end{array}$ & $\begin{array}{c}\text { Alkalin- } \\
\text { ity. }\end{array}$ \\
\hline Center . & 86.0 & 42.0 & 49.0 & 41.0 \\
\hline $1 \ldots$ & 64.0 & 27.2 & 42.5 & 43.7 \\
\hline $2 \ldots$ & 64.4 & 23.2 & 36.0 & 46.5 \\
\hline $3 \ldots \ldots$ & 64.4 & 26.4 & 41.0 & 45.5 \\
\hline $4 \ldots \ldots$ & 65.6 & 25.2 & 38.4 & 46.5 \\
\hline $5 \ldots \ldots$ & 58.0 & 26.8 & 46.2 & 45.6 \\
\hline $6 \ldots$ & 56.0 & 20.8 & 37.1 & 45.6 \\
\hline $7 \ldots \ldots$ & 49.6 & 23. 6 & 47.6 & 46.5 \\
\hline $8 \ldots$ & 60.0 & 27.2 & 45.3 & 47.0 \\
\hline $9 \ldots \ldots$ & 57.6 & 23.2 & 40.3 & 46.5 \\
\hline $10 \ldots \ldots \ldots$ & 60.0 & 22.4 & 36.5 & 46.0 \\
\hline
\end{tabular}

B LINE.

\begin{tabular}{|c|c|c|c|c|}
\hline Center ............. & 86.0 & 42.0 & 49.0 & 41.0 \\
\hline $1 \ldots \ldots$ & 61.6 & 23.2 & 37.6 & 44.5 \\
\hline $2 \ldots \ldots \ldots$ & 67.2 & 21.6 & 32.1 & 45.6 \\
\hline $3 \ldots$ & 72.8 & 32.4 & 44.5 & 44.5 \\
\hline $4 \ldots$. & 66.0 & 31.2 & 47.2 & 45.6 \\
\hline $5 \ldots \ldots$ & 74.0 & 31.2 & 43.2 & 45.6 \\
\hline
\end{tabular}

The diminution in the portion of dissolved volatile solids along the line from the center to the outer extremity is not uniform. The water is subject to variation in organic contents by reason of influences other than those of the river. Sample 2, taken at a distance of about 1 mile from the shore, indicates a practically normal water, containing in fact the smallest percentage of volatile solids noted in connection with the entire range of Ausable samples, while the alkalinity differs only slightly from the normal. This would seem to show that, from the effects either of current or of wind, a stream of purer water from the broad lake was carried inshore, for it will be noted, on inspection of the results, that there is an immediate rise in the percentage of volatile solids at sampling point 3 , which reaches a maximum at point 4 , being here nearly as great as at the center.

Conclusions. - The results of the three series of samples taken from the lake at and in the region of the mouth of Ausable River show that the sulphite waste certainly affects the lake to a considerable extent. If we accept the tests which are used as specific there can be no doubt concerning this conclusion. It is probable, however, that the testimony made by the tests is not so direct and unimpeachable as 
that afforded by the tests selected in the case of the Bouquet River pollution. It is certain that the percentage of volatile solids is a dangerous test to use unless all the facts and conditions attendant upon - its use are taken into consideration. We may conclude at once that the volatile solids in the water of the lake represent largely the organic matter dissolved therein. It is probable that a minute proportion of the matter lost upon ignition is of an inorganic nature, but the amount in comparison with that which represents organic matter is sufficiently small to be negligible. It has been shown that the waste turned into Ausable River from the pulp mills is highly organic and somewhat acid in its nature, and therefore we may expect, and indeed do find, that the amount of organic matter in the water discharged from the river into the lake is exceedingly high. It only remains, therefore, to eliminate other sources of organic matter in order to show that the excess of organic matter in the region about the mouth of the river is due finally to the sulphite waste. Examining the conditions as they appear in this region, it will be seen that, with the exception of Ausable River, there is no source of organic pollution along the lake of any consequence for a distance of 10 miles. Plattsburg, N. Y., and Burlington, Vt., are the only points from which organic matter in any amount could come, and, as will be shown in subsequent discussion of the Burlington pollution, the organic matter in the sewage discharged from this place is not sufficient in quantity to be determined with any definiteness by the volatile solids test. Indeed, there can be no organic pollution the evidences of which would persist in the samples taken around the mouth of Ausable River other than that of the river itself.

The foregoing considerations lead to the question whether or not the amount of organic matter in the broad lake varies in any large degree. If, for example, the water at the points from which samples were taken upon which to base the standard in Table III, collected on July 26, contains a larger amount of organic matter in September merely by reason of natural causes, then the standards selected are not trustworthy for use in connection with these investigations of Ausable River. An examination of water from several unpolluted points in the lake was therefore made for the express purpose of determining whether there were any important variations in the amount of organic matter contained in this water between the two dates above mentioned. The following results were found:

Volatile solids in Lake Champlain water at unpolluted points. 
It will be seen from these results that the total amount of organic matter in the water was slightly greater in September than in July, and in interpreting the results of the determinations in connection with the Ausable River pollution this should be taken into account.

The determination of alkalinity is absolute, however, and taken in connection with the amount of organic matter as determined by the percentage of volatile solids, is unmistakable. The proper course will therefore be to give little value to the results of the volatile-solids determination, which appear high, but which are not accompanied by a low alkalinity, insisting upon the agreement of the two determinations. Following out this plan, the results of the various investigations with reference to Ausable River are, briefly, as follows:

The effect of sulphite waste from Ausable River in Lake Champlain is apparent north of the river's mouth for a distance greater than $2 \frac{1}{2}$ miles, ihe distance apparently varying according to the prevailing winds. East from the river's mouth into the broad lake the effects are generally appreciable for about 1 mile from the shore, while south from the river the water is certainly affected at times as far south as Willsboro Bay, but usually not farther south than Trembleau Point. The line at which the effect of the river becomes inappreciable in the lake was not determined, for such an investigation would require a large amount of time, covering several seasons at least. From all the indications afforded by the series of samples taken, the line at which the water of the river merges completely into that of the lake is exceedingly irregular, varying according to prevailing winds. It certainly extends considerably farther along the shore, both north and south, than it does eastward into the broad lake.

Having determined that sulphite waste is appreciable for considerable distances into the lake, it becomes necessary to consider what effect this waste may have. As above stated, the waste is composed largely of organic matter, and the effects which it would have must be interpreted according to organic standards. Primarily the character of the organic matter is not harmful to health. It contains no organisms of specific disease, and therefore can not be regarded initially as a menace to the public health. Undoubtedly, however, this organic matter forms a nidus for the development of bacteria in large numbers. Although there was no opportunity to make experiments with reference to the persistence of intestinal bacteria, it is probable, judging from analogous experiments made elsewhere, that such germs would thrive better in water containing this organic matter than in the normal water of the river and lake. So far as a specific disease is concerned, this waste does not do as much initial damage to Ausable River as the sewage which issues from several private sewers in the village of Keeseville. Nevertheless, this does not by any means relieve the 
pulp company from responsibility. The measure of damage to the lake by this waste is difficult to determine. The damage to the stream, as has been stated on previous pages, is unquestioned.

There is a certain amount of damage done to the lake, this amount varying according to local conditions. The increased organic matter shown in the above tables is probably responsible for an increased number of bacteria, and there is little doubt that the specific germs of disease would persist longer in this water than in that in other parts of the lake. While it is undoubtedly true that the water of the lake is not so good along the western shore, in the area covered by the investigations, as in the broad lake, the damage is not definite, and it would be impossible to state its actual extent.

In connection with the question of algæ, it has been asserted that this waste is the cause of a more profuse growth than would normally occur along the shores. Certain algæ thrive in water containing a high proportion of organic matter, and the natural inference would be that they would be more abundant in the region under the influence of Ausable pollution than they would if no polluted matter were present. Such abnormal abundance is not discernible, however. There is no greater amount or greater variety of algæ in the lake around the mouth of this river, nor indeed in any part of the lake, than might be expected in an unpolluted body of water.

The pollution from Ausable River discharged into Lake Champlain is by no means cumulative. The conditions as they were found in the series of examinations are without doubt as bad as they ever have been or ever will be. In other words, the organic matter turned into the lake from the river is unstable. It changes from the complex substance to the simple inorganic form and passes out through the lake outlet, diluted so largely with the tremendous volume of purer water as to be unrecognizable.

The waste pulp, an inert cellulose, can of itself exert no harmful effects. It piles up along the shores, makes them unsightly, and undergoes little change. Therefore, while the effect of the pulp waste upon the lake is pronounced and unmistakable, its area of influence is comparatively small and whatever damage may be done does not extend to the entire lake. The damage is therefore more a private than a public one at the present time, and has caused no apparently serious results beyond a limited area.

IRR $121-05-5$ 


\section{BURLINGTON AND WINOOSKI RIVER.}

\section{SEWAGE POLLUTION.}

\section{SOURCES OF SEWAGE AND PLACES OF DISCHARGE.}

Burlington, Vt., has, according to the Twelfth Census, a population of 18,640. It is situated on the east side of Lake Champlain, in the center of a broad bay, shown in fig. 4 (p. 77). The water supply of the city is pumped from the lake--the intake being situated northwest of the city at Appletree Shoal-through a suction pipe extending along the bottom of the lake to the pumping station on the lake front, nearly opposite the north end of the harbor breakwater. The sewage of the city is carried by a trunk sewer to the water front and emptied into the lake at the shore nearly due east of the south end of the breakwater $(\mathrm{Pl} . \mathrm{X}, A)$. The outlet is marked by the opening in the timber pier shown in $\mathrm{Pl}$. X, $B$. All sewage except a small, insignificant quantity is discharged through this outlet.

Into the small bay defined by Lone Rock Point and Appletree Point are discharged the wastes of an extensive rendering establishment.

About 2 miles north of Appletree Point, Winooski River enpties into the lake (fig. 7, p. 87). This river drains 995 square miles in the State of Vermont, most of it farming or mountain land. Near the upper end of the river is situated the city of Montpelier, and near the mouth are Fort Ethan Allen, an extensive United States Army post, and the village of Winooski, containing 3,783 inhabitants. Fron both the army post and Winooski village are discharged large quantities of sewage.

The geographic relations of the various points above mentioned to the configuration of the shore are important, as they are such as to protect large areas of water and render them comparatively stagnant; that is, they are so situated that circulation must be considerably less than that in the broad lake. A few miles south of Burlington, She]burne Bay, a large body of water from 70 to 100 feet in depth, makes into the mainland. Shut in from the rest of the lake except at the comparatively narrow outlet between Shelburne and Red Rock points, this bay is comparatively stagnant. A slight current from the north seems to flow along the shore above Red Rock and circulate in the bay. This is quite pronounced when a strong north or northwest wind is blowing. This bay is therefore considerably polluted by the sewage of Burlington, and on account of the lack of dilution the water reveals a somewhat higher amount of organic matter than has been noted in the water of the broad lake. Burlington is protected by a long, artificial breakwater around which the current swirls, the direction depending largely upon the direction of the prevailing winds. It has been noted by various observers that when the wind blows from the south 


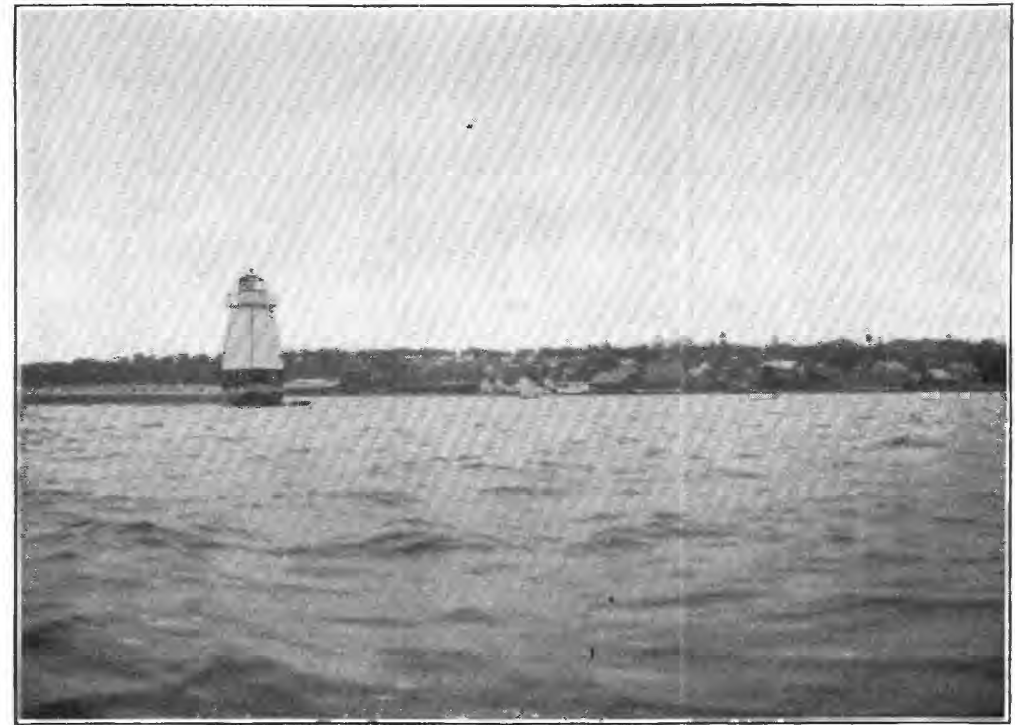

A. BURLINGTON, VT., LAKE FRONT.

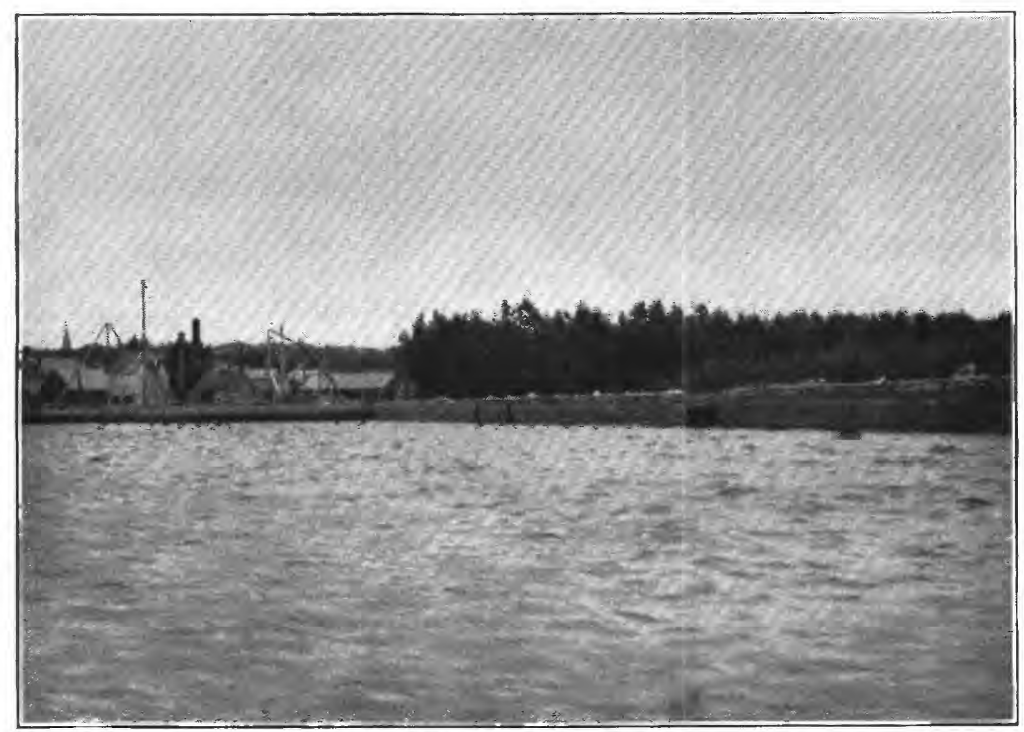

B. TRUNK SEWER OUTLET, BURLINGTON, VT. 
the current seems to be deflected from the lake into the south end of Burlington Bay, thence northward inside the breakwater. Similarly during a northerly wind the subcurrent runs south behind the breakwater. Just north of Burlington there is a small area of comparatively dead water eastward from Lone Rock Point. Between Lone Rock Point and Appletree Point there is another bay well protected except from southerly winds. This is the bay into which the offal from the rendering establishment is turned, and at the mouth of which, on Appletree Shoal, the water intake of the city has been placed. North of this, Winooski River makes out into the lake at a southerly angle, the current deflecting southward even when the lake surface is quiet. Now, as has been stated on previous pages, the normal current of the lake at the shore is southward. The water of Winooski River when discolored by floods is readily traceable southward into the lake, the track having been observed as far south as Juniper Island when strong northerly winds were prevalent.

\section{EFFECT ON LAKE CHAMPLAIN.}

The conditions above recited seem to be well adapted for confining the impurities coming from the Burlington sewers and from Winooski River in that immediate region, the trend of the impurities varying with the immediate local conditions. Normally, without winds, the sewage from Burlington takes a southerly turn along the shore of the lake and swings outward, taking a northerly course by Appletree Point, or a little farther to the west. The water of Winooski River apparently flows south and then swirls into the broad lake in the same manner; thus the impurities are concentrated first at one place and then at another, the ultimate mixture giving to the water in the region of Burlington and for several miles north, south, and west a character which by no means warrants its consumption for domestic purposes in the raw state. The impurities issuing from Burlington and the Winooski are almost entirely of a sewage nature, there being very few industries the waste from which complicates the pollution problem in an important degree. The specific tests by which this pollution can be traced are the familiar ones commonly used in sewage-pollution cases. There should be under normal conditions a general increase in the amount of chlorides in the water, a slight rise of the amount of organic matter, but most of all a surplus of intestinal bacteria, of which the Bacillus coli communis is the most familiar. Before taking up the consideration of the specific tests which were made in connection with this problem, it will be instructive to review briefly the history of the Burlington water supply and show the effect which the discharge of sewage has had upon it. 
The facts recited below with reference to the earlier history of the Burlington water supply are condensed from a paper written by Prof. William T. Sedgwick, of the Massachusetts Institute of Technology, entrtled "The Sanitary Conditions, Past and Present, of the Water Supply of Burlington, Vt.," which was read before the New England Water Works Association, and printed in the journal of that association, vol. 10 , pages 167 to 183 , inclusive:

"The Burlington waterworks were constructed in 1867 after considerable discussion and investigation concerning proposed sources. Lake Champlain was finally selected and an intake pipe was established at the northern extremity of the Burlington docks. At first the water gave satisfaction, but from 1871 on there developed considerable uneasiness concerning the dangers arising from the proximity of the water intake and the trunk sewer outlet. The statement generally made in the reports was that while little or no specific water-borne disease had occurred, the condition was a constant menace and might result at any time in a serious epidemic. Suggestions were repeatedly made that the intake pipe should be extended for a considerable distance into the broad lake.

"As years passed intestinal troubles, usually in the form of mild diarrheal disturbances, prevailed, and in the years 1882,1884 , and 1889 typhoid became epidemic. Still, when compared with other eities with undoubtedly pure supplies, the typhoid rate in Burlington was not excessive.

"In 1888 the subject had reached such importance that an investigation relative to the merits of various available supplies was begun. The report of this investigation was published in 1889 in the twentyfifth annual report of the city of Burlington, pages 95 to 113 . This report contained the results of a series of analyses and a discussion of the same by Mr. Joseph L. Hills, chemist of the State agricultural experiment station. In this discussion Mr. Hills stated as follows: 'The station chemists have not been able to detect evidences of sewage in samples from Marks Bay or the pumping station (or indeed in a series of samples taken about 100 yards away from the sewer mouth in the endeavor to trace the direction of sewage currents). *** One of the most interesting points *** is that the water from the broad lake does not appear purer than that taken inshore. *** It does not appear settled that the extension of the suction pipe will of necessity give our community a purer water supply.""

With reference to the results of this investigation, Mr. F. H. Crandall, superintendent of the waterworks, stated that they (the results) "afford a subject of careful thought and study, as well as a chance for interesting comparisons." 
Some of the analytical statements with reference to the water of the lake made in the report above cited are reproduced below in order to show the condition of the water at that time as clearly as the data given admit of interpretation and for purposes of comparison with results of analyses made during the recent investigations.

TABLE XV.-Chemical analyses of the water supply, etc., of Burlington, Vt., previous to May, 1889.

\begin{tabular}{|c|c|c|c|c|c|c|c|c|}
\hline Source of sample. & Date. & Analysis by- & 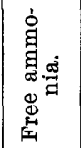 & 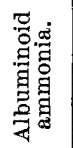 & 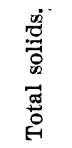 & 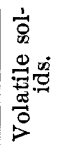 & 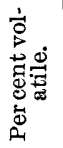 & 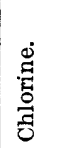 \\
\hline $\begin{array}{l}\text { Mouth of suetion pipe, pump- } \\
\text { ing station. }\end{array}$ & Sept., 1884 & Sabin..... & 0.16 & 0.15 & 36.0 & & & \\
\hline Do $\ldots \ldots \ldots \ldots \ldots$ & .....do..... & Witthaus..... & .052 & .13 & 72.0 & & & 2.1 \\
\hline Do ...................... & Mar., 1885 & $\ldots$. do $\ldots . . . \ldots$. & .034 & .10 & 89.0 & & $\cdots .$. & 1.1 \\
\hline Do $\ldots \ldots \ldots \ldots . . . . . . . . . .$. & .....do...... & W. R. Nichols .. & .02 & .15 & 71.0 & 14 & 19.7 & .2 \\
\hline Do $\ldots \ldots \ldots \ldots \ldots \ldots$ & ..... do ..... & Seeley .......... & ..... & ..... & 60.0 & 19 & 21.7 & $\ldots$ \\
\hline Do ........................ & Jan. 8, 1889 & Hills ........... & .03 & .18 & 88.5 & 34 & 38.4 & 1.7 \\
\hline $\begin{array}{l}\text { Northwest corner breakwater, } \\
10 \text { feet deep. }\end{array}$ & Sept., 1884 & Sabin........... & .06 & .114 & 119.0 & & & \\
\hline Do......$\ldots \ldots \ldots \ldots$ & .....do..... & Witthaus...... & .026 & .11 & 84.0 & & & 1.5 \\
\hline Do $\ldots . . . . . .$. & Mar., 1885 & ..... do ........... & .016 & .08 & 75.0 & $\cdots$ & . & 1.1 \\
\hline Do ......... & .... do do.... & W. R. Niehols .. & Trace. & .08 & 73.0 & 13 & 17.8 & 2.0 \\
\hline Foot of Bank street ............. & Jan. 8, 1889 & Hills ........... & .02 & .19 & 86.0 & 37 & 43.0 & 1.4 \\
\hline $\begin{array}{l}\text { Northwest corner breakwater, } \\
26 \text { feet deep. }\end{array}$ & Sept., 1884 & Witthaus....... & .146 & .17 & 79.0 & & & 1.8 \\
\hline Do $\ldots \ldots \ldots \ldots \ldots \ldots$ & Mar., 1885 & .....do.......... & .34 & .08 & 76.0 & & & 1.0 \\
\hline Do & ..... do ...... & W. R. Nichols .. & Trace. & .08 & 70.0 & 15 & 21.4 & 1.8 \\
\hline Marks Bay, 58 feet deep ....... & Sept., 1884 & Sabin........... & .48 & .10 & 107.0 & & & $\cdots \cdots$ \\
\hline Marks Bay, 62 feet deep ....... & .....do do.... & Witthaus....... & .08 & .10 & 56.0 & & & 5.8 \\
\hline Marks Bay ....................... & Mar., 1885 & .....do........... & .034 & .05 & 66.0 & ...... & & .9 \\
\hline 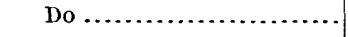 & Jan. 8, 1889 & Hills ........... & .03 & .16 & 80.0 & 35 & 43.7 & 2.9 \\
\hline $\begin{array}{l}\text { Surface, midway sewer mouth } \\
\text { to south end breakwater. }\end{array}$ & Sept., 1884 & Sabin........... & .04 & .072 & 100.0 & & $\cdots \cdots$ & ... \\
\hline Do $\ldots \ldots \ldots \ldots \ldots \ldots \ldots$ & ......do ..... & Witthaus... & .08 & .13 & 116.0 & & & 9.7 \\
\hline $\begin{array}{l}3,000 \text { feet west of pumping sta- } \\
\text { tion. }\end{array}$ & Mar., 1885 & Seeley ...... & & & 69.0 & 17 & 24.6 & $\cdots \cdots$ \\
\hline Rock Point ..... & & & & & 61.0 & 17 & 27.9 & $\cdots \cdot$ \\
\hline
\end{tabular}

"Mild epidemics of diarrhea" continued, with the result that the reassurance established by the report above mentioned gave place to further alarm. The typhoid rate, according to clinical diagnosis of that period, was still sufficiently low to be insignificant. It would be interesting to know how much of this so-called "diarrhea" would, under modern methods of culture diagnosis, be recognized specifically as typhoid fever.

The above statements describe the situation when, in 1892, Professor Sedgwick was invited to make an investigation. In his paper, read some years later before the Water Works Association, ${ }^{a}$ he sums up the situation, as it then existed, as follows:

First. It was widely held by physicians and understood by the people that diarrhea was common among users of the water, especially those who had not 
become habituated to it, visitors to Burlington, if they drank the water, frequently suffering from some diarrheal disturbance.

Second. The location of the intake of the waterworks was less than a mile from the outfall of the main sewer and only a few rods from the docks.

Third. Typhoid fever, the ordinary measure of the sanitary condition of a water supply, was not then, and had seldom been, excessively prevalent in Burlington.

Fourth. Chemical analyses had failed to show any marked superiority in the water of the broad lake (the middle of Lake Champlain) to that at the intake on the shore of Burlington Bay.

Sixth. Investigations had proved that it would be difficult, uncertain, and costly to procure a gravity supply from the mountains, because of their remoteness and for other reasons.

It is only fair to add that at the time of my investigations and of making my report I was less familiar with some of these facts than I am now.

Previous to 1892 the sewer outfall had frequently attracted the attention of physicians and other citizens. When the water in the lake was low the sewage from the main sewer was not discharged into the lake beneath the surface, or even on the lake front, but ran in an open stream over flats laid bare by the receding waters and emptied into a small bay or basin connecting with the lake. The stench which at times arose from this torpid stream, from the flats, and from the bay was highly obnoxious and objectionable, so that a demand had come, especially from the board of health and its efficient health officer, Dr. H. A. Crandall, for an improved outfall. Mr. F. P. Stearns, C. E., engineer in chief of the State board of health of Massachusetts, was finally consulted, and advised an extension of the outfall to the main lake front, with disposal there directly into the lake, and at a depth sufficient to be always below the surface.

I had already been making (in Boston) occasional bacterial analyses of the city water, the water of the lake, etc., for the water commissioners of Burlington, when, on June 20, 1892, I was invited by them to visit the city and make a thorough investigation of the sanitary condition of its public water supply, present and prospective. I did as I was desired and subsequently presented a report, of which the following is the principal portion:

The Board. OF WATER CoMmissioners,

Boston, June 30, 1892.

Burlington, $V t$.

Gentlemen: I have the honor to submit to you a report upon my investigations, made at your request, concerning the sanitary condition of the Burlington water supply and the probable sanitary effect of certain proposed changes therein.

I am informed that many of the physicians regard the water supply with suspicion, and I find that the successive health officers in their official reports have frequently referred to the water as more or less objectionable. I therefore undertook, first, to discover the actual effects of the water supply upon the health of the city.

In order to do this in the case of a water supply suspected of sewage contamination it is customary to take as a measure the prevalence of diarrheal diseases and especially typhoid fever. I have therefore carefully studied the vital statistics of Burlington for the last twelve years, comparing the mortility from typhoid fever with the total mortality and also with the number of inhabitants.

The results show conclusively that the mortality from typhoid fever (and the same is true for diarrhea and dysentery) has not been large in Burlington during the last twelve years. The average annual mortality from typhoid fever from 1870 to 1891 in Burlington was 3.57 per 10,000 inhabitants.

I then went on to show that Burlington compared favorably in this respect with many cities having water supplies of undoubted purity, and stated that in respect to mortality from typhoid fever it had a better record than " many cities having water 
supplies of good reputation." This weighty fact alone justifies the conclusion that there is no positive evidence in the sanitary statistics of the city that the water supply is injurious to public health. I may add by way of confirmation that during the last three years I have made repeatedly bacteriological analysis of the Burlington supply, and that I have found no satisfactory evidence of the presence of sewage in the drinking water.

It is interesting and instructive to compare the history of typhoid fever in Burlington during the last six years with that during the earlier half of the period under consideration, for in this way we may learn whether this disease is or is not increasing. If we do this we obtain the following results:

Statistics of typhoid fever in Burlington, Vt.

\begin{tabular}{|c|c|c|}
\hline & \multicolumn{2}{|c|}{ Six-year periods. } \\
\hline & 1880-1885. & $1886-1891$. \\
\hline $\begin{array}{l}\text { Average annual death rate from typhoid fever per } 10,000 \text { in- } \\
\text { habitants }\end{array}$ & 3.39 & 3. 75 \\
\hline Average annual mortality percentage from typhoid fever ..... & 1. 73 & 1.83 \\
\hline
\end{tabular}

These figures are certainly reassuring, and prove conclusively that there is no immediate reason for excessive anxiety or alarm for the sanitary condition of the water supply.

It is, however, the opinion of many Burlington physicians, based upon their experience, that the water supply is responsible for the occurrence from time to time of diarrheal disturbances which, while they very rarely result in death, serve to annoy and alarm the citizens. In the present state of our knowledge it is at present impossible to prove or to disprove this theory. The fact appears to be that such disturbances are common, and it is well known that the main sewer of the city empties into Lake Champlain, the source of the water supply, less than a mile from the intake. Whether there is anything more than coincidence in these facts it is impossible to say. In the present state of sanitary science, however, there can be no doubt whatever that the location of the intake of the waterworks, as near as it now is to the main sewer of the city, is highly objectionable, if not positively dangerous. I can only regard it as a constant menace to the sanitary welfare of the city. It must be admitted as entirely possible that unpurified sewage driven by winds or carried by currents may be in the future, if it has not been in the past, conveyed more or less directly from the sewer outfall to the water intake.

I have, therefore, at your request, considered the probable sanitary advantages of a removal of the intake of the waterworks to a point in the "broad lake" some 3 miles from its present position, and also those of a complete change from the lake to a mountain supply.

In regard to the former--the broad-lake supply-I am of the opinion that it would be of very great advantage from a sanitary standpoint, inasmuch as it would so far remove the intake from the sewer outfall as to make it unlikely that raw sewage would ever pass from the latter to the former, while at the same time it would give more time for the purification en route of any sewage which might accidentally so pass. Unless the city should become very much larger than it now is, the passage of sewage from the sewer outfall to an intake located, for example, on Appletree Reef, through the present sewer basin and the quiet waters of the bay, can only be regarded as a remote possibility. 
I may remark in passing that, in my judgment, one reason for the comparative immunity Irom epidemics of typhoid fever hitherto enjoyed by this city is that the sewage is leld in a small bay for a longer or shorter time, according to circumstances, whe re it can to some extent become freed from the germs of disease.

If Burlington could draw its water supply by gravity from mountain streams or storage reservoirs and secure abundant water from an unpolluted watershed the danger of infection of the water supply would be done away. So far as I can judge, however, there are no streams of sufficient size and purity directly available. Storage would be an unavoidable necessity. But storage, while of great sanitary advantage so far as the germs of specific diseases are concerned, is apt to lead to disagreeable consequences in other directions. The water drawn from storage reservoirs is often more or less colored by peat, stumps, leaves, etc., and not infrequently suffers fermentation with the development of organisms, acquiring thereby disagreeable and sometimes nauseous tastes and odors. If these compel the citizens to abandon its use and lead them to resort to polluted wells or other objectionable sources of supply, the sanitary consequences may be unfortunate. It will be seen, therefore, that, while a mountain supply is in many respects highly desirable, it is nevertheless true that its adoption in this case would be attended with the possibility of some undesirable consequences. It must be remembered that every new water supply depending upon the storage of surface water is an experiment. It can not be undertaken without some risk of undesirable results.

In fine, I am of the opinion that there is no positive evidence of any injurious characteristics in the present supply. But I believe nevertheless that in view of the common occurrence of diarrheal disturbances reported by physicians, and on account of the menace to the public health involved in the present arrangement, some other source of supply should be found. I think that it would be of very great sanitary advantage to remove the intake as far as possible out into the broad lake. A mountain supply in storage reservoirs would afford complete relief from sewage or contamination, but might involve serious troubles with microscopical organisms, tastes, and odors.

Respectfully submitted.

William T. SeDGwick.

This report was generally accepted as establishing the fact that, while there was no occasion for immediate alarm or excessive anxiety, it was imperative that steps should be taken as soon as practicable to improve the situation. The epidemics of 1882,1884 , and 1889 were not forgotten, and the figures submitted by me showed a perceptible, though slight, increase of typhoid fever and diarrheal disturbance during the more recent six-year period. Accordingly, after still further deliberation, it was decided to extend the intake pipe some 3 miles from the sewer outfall into the lake, to a point known as Appletree Reef, which had been found by repeated bacterial analyses to be a favorable one for the purpose. This extension, as has been fully described in the preceding paper by Mr. Crandall, was made in the summer of 1894 . Its completion was undoubtedly hastened by the improved sewerage plan recommended by Mr. Stearns in 1892, and about to be carried out by the sewer commissioners, by virtue of which the main sewer outfall would be pushed outward to the lake front and the sewage discharged at all seasons beneath the surface of the lake. As soon as this improvement became assured, Mr. Crandall and the water commissioners, as well as the board of health, redoubled their activity in urging that the intake of the water supply should be moved farther out into the lake, and all the more because the little bay in which at certain seasons the sewage fermented and doubtless worked itself to some extent free from disease germs was now to be obliterated, so that fresh sewage might at times readily find access to the currents, if any, along the lake front at a point less than a mile from the intake of the waterworks.

I have lately had made by an assistant-Mr. S. C. Prescott, in the laboratory of the Vermont agricultural experiment station, kindly placed at our disposal by Professor 
Jones, to whom our hearty thanks are due-a series of careful bacterial analyses of water taken from various points on the high service and the low; at the pumping station; from the pump well, and from the lake just outside, a point which corresponds to the old intake; from the lake front near the sewer outfall, and from the new intake on Appletree Reef. These show conclusively, both by comparison with analyses made before the extension of the intake and by comparison one with another, that the removal of the intake to a distant point in the lake has caused a marked bacterial improvement in the purity of the city water.

In discussing the results of the biological investigations made in connection with his examination, Professor Sedgwick demonstrated by actual plate cultures of equal amounts of water from different parts of the lake the progressive disappearance of bacteria from the sewer outlet, where they abounded, to the old intake, where they were relatively few yet far more numerous than at the new intake or at any point in the service pipes. In connection with this he submitted sanitary analyses showing the amounts of organic matter at the old intake of the lake and in the city water after the intake was extended to Appletree Reef, and the condition of that organic matter, as follows:

TABLE XVI.-Sanitary analyses of water of Lake Champlain at new and old intakes.

\begin{tabular}{|c|c|c|}
\hline . & $\begin{array}{l}\text { Lake (old } \\
\text { intake). }\end{array}$ & $\begin{array}{l}\text { Tap (city } \\
\text { service). }\end{array}$ \\
\hline Total solids........ & 66.00 & 62.00 \\
\hline 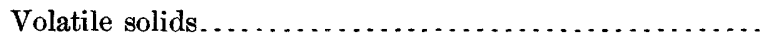 & 12.5 & 10.5 \\
\hline Per cent volatile................... & 19.00 & 16.9 \\
\hline Albuminoid ammonia........ & .138 & .120 \\
\hline Free ammonia ........... & .01 & .00 \\
\hline 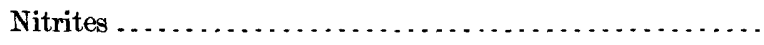 & .00 & .00 \\
\hline Nitrates.............. & .01 & .10 \\
\hline Oxygen consumed .... & 2.730 & 2.496 \\
\hline 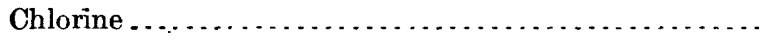 & 1.40 & 1.00 \\
\hline 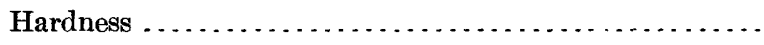 & 42.00 & 42.00 \\
\hline 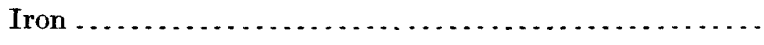 & .06 & .06 \\
\hline \multicolumn{3}{|l|}{ Microscopical organisms in 100 cubic centimeters: } \\
\hline Diatoms $\ldots \ldots \ldots \ldots$ & 3,550 & $1,05 n$ \\
\hline Algæ & 1,400 & 6,200 \\
\hline Blue-green algæ $\ldots \ldots \ldots \ldots \ldots \ldots \ldots \ldots \ldots \ldots$ & 200 & 150 \\
\hline
\end{tabular}

In discussing the improvements brought about by the extension of the intake pipe into the lake, Professor Sedgwick, reported as follows:

But there is yet another kind of evidence which witnesses still more eloquently to the improvement of the water supply. This is the testimony of the physicians of Burlington. As far as I have been able to communicate with them-and I have interviewed a number of the most prominent and representative-there is a surprising and remarkable unanimity of opinion among the local physicians to the effect that 
the peculiar diarrheal disturbances which had so long prevailed in Burlington have, since the extension of the intake pipe, wholly ceased; and the physicians are enthusiastic in their recognition of the salutary change, which they attribute entirely to the improved water supply.

In view of all the evidence at hand-statistical, bacteriological, chemical, and medical-I think we may safely conclude that the sanitary condition of the water supply of Burlington is now most excellent. If, however, in the future Burlington grows extensively and becomes a much larger city it will probably become necessary here, as in most large cities, to face once more the question of a pure water supply. Special pains must also be taken to see to it that the intake pipe is kept intact and free from leakage. The unfortunate experiences of Toronto and Buffalo with broken intake pipes afford ample warnings in this direction.

This is the first case within my own experience, now somewhat extensive, in which epidemic diarrhea in a mild form has prevailed in a community for many years, having its etiology in the consumption of impure water, as has been proved by its apparent total disappearance on a change in the source of supply. The importance of the case in the history of water-borne diseases is manifest. It was complicated by the fact that typhoid fever, which is usually taken as a measure of the sanitary condition of the community, was here ordinarily by no means excessive, and that its occasional prevalence might easily have been due to some other cause than polIuted water. The fact seems to be, however, that it was in truth really due to impure water, inasmuch as since the extension of the intake pipe in 1894 typhoid fever has practically disappeared. If would seem fair to conclude, from the moderate occurrence of typhoid fever, while diarrhea abounded, that germs of the latter disease, more hardy than those of the former, were frequently able to survive a journey from the sewer outfall to the water intake, while those of typhoid fever, if present, usually perished. In future sanitarians will not be able, by the test of typhoid fever alone, to show that a water supply is above suspicion. A mild form of diarrhea caused by polluted water may apparently prevail even in the absence of any constant or considerable excess of typhoid fever.

\section{PRESENT CONDITIONS.}

The statements above recited with reference to the water supply of Burlington indicate in a measure the condition of the lake in front of the city twelve years previous to the investigation of which this publication is a report. Since that time the population of Burlington has increased about 30 per cent. Therefore, the conditions, admittedly bad during that period, must of necessity be still more unfavorable at the present time. It is therefore safe to enter upon the investigation with the assumption that Burlington sewage does damage the lake, and the problem resolves itself into a question of the extent of that damage.

One of the most striking features in connection with Burlington pollution brought out by the report of Professor Sedgwick is the apparently enormous power possessed by the lake to assimilate large quantities of contaminating matter and to conceal almost every chemical as well as biological evidence of the presence of pollution. It is inevitable that the increased quantity of sewage resulting from the increase in population above stated will render the detection thereof in the lake 
a less difficult matter than during the period covered by Professor Sedgwick's report. In addition to this, the interesting question presents itself, whether or not by the continued pollution, year after year, the lake immediately surrounding has lost a part of the remarkable power which it was at that time shown to possess of assimilating these impurities and making their detection difficult. Undoubtedly precipitation of the organic matter is a great feature of this so-called assimilating power, and it has been well shown that the continued sedimentation of putrescible matter will in time result in such large accumulations that the actual conditions will assume those somewhat similar to a septic tank. In other words, the area will become a seat of fermentative changes, the result being that the character of the surrounding water reveals these conditions and.a large part of the power to conceal sewage is lost. No opportunity was afforded to investigate with reference to this particular point, but the results hereinafter submitted contain interesting suggestions with reference to it.

Burlington sample series of September 16.-The first samples taken to determine the extent of Burlington pollution were from along the shore of the lake, south of the city and continuing around the shores of Shelburne Bay. This course is indicated in fig. 4 (p. 77), showing sampling points 1 to 19 , beginning a few rods south of the southernmost end of the Burlington breakwater and, after circling around the bay, ending a short distance east of Shelburne Point. The determinations made with these samples consisted of (1) total solids on evaporation, (2) loss on ignition, (3) per cent loss on ignition, and (4) chlorine. No biological samples were taken in this series, as the principal object was to determine whether or not intelligent results could be secured by chemical means only. It was well understood that with the normal conditions of current southward the water of the lake off the shore from Red Rock Point to Burlington Harbor would be distinctly polluted with sewage. The results of the determinations in this series of samples are set forth in Table XVII. 
Table XVII.-Burlington pollution sample series of September 16, 1904.

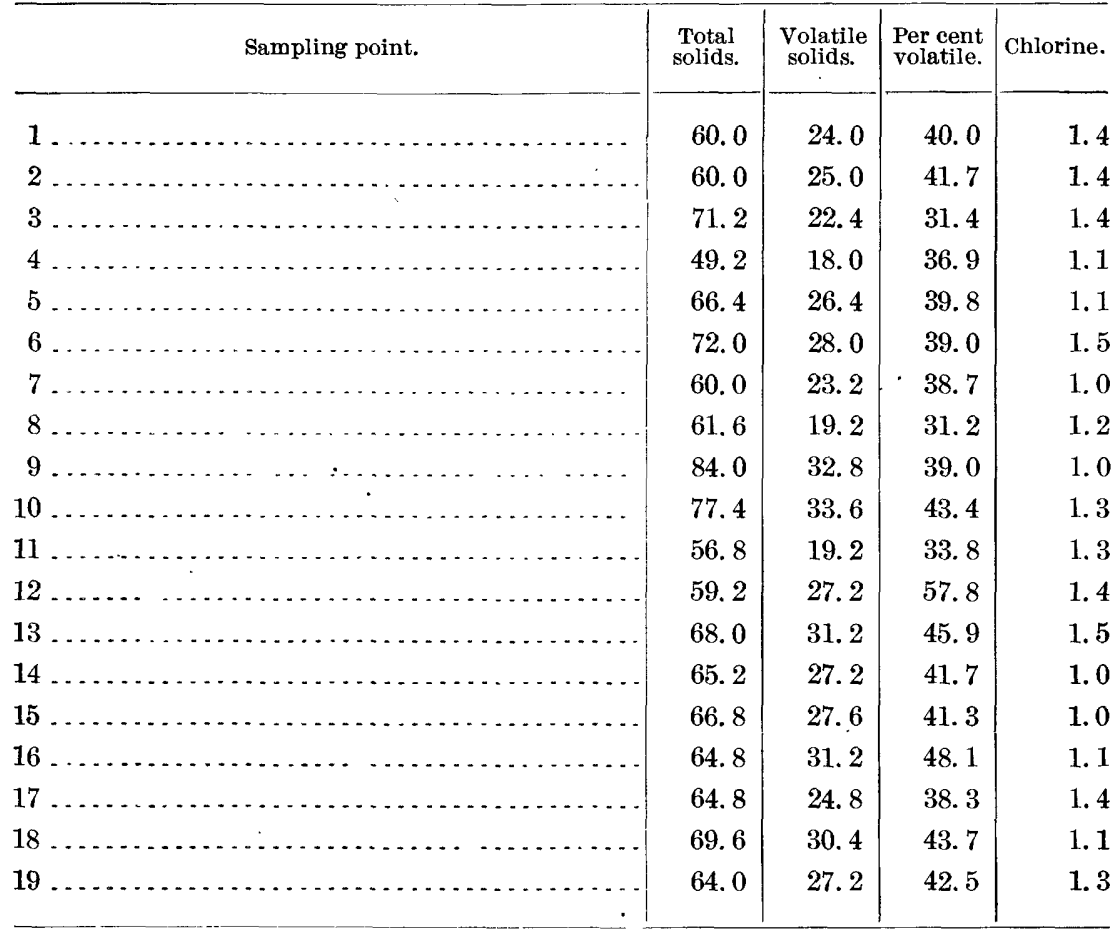

Although the results set forth in the above table indicate unmistakably the polluted condition of the water in the region in which the samples were taken, there appears to be no continuity nor general logical trend as the distance from the polluting point is increased or diminished. The results also emphasize the fact that although a large amount of sewage matter is turned into the lake at Burlington the determination of volatile solids does not set forth the conditions clearly. This determination is therefore unworthy of confidence except in those cases where the accompanying determinations agree relatively with them. A few of the samples, such as Nos. 10, 12, 13 , and 16 , show a percentage of volatile solids considerably higher than the normal for the lake, and it will be noted that the chlorine in those samples is abnormally high. On the other hand, the results of the determination in sample 6 show a normal amount of volatile solids with extraordinarily high chlorine. As might be expected, the chlorine determinations give the specific results valuable in the investigation. It will be seen that by far the greater majority of the samples contained an amount of chlorine considerably higher than the normal. This can be due to nothing else than the Burlington sewage. On the other hand, there were several samples containing a 
normal amount of chlorine, which may be explained by the statement that the dilution by the purer water from the broad lake must be irregular in the bay, as in fact the physical conditions would indicate.

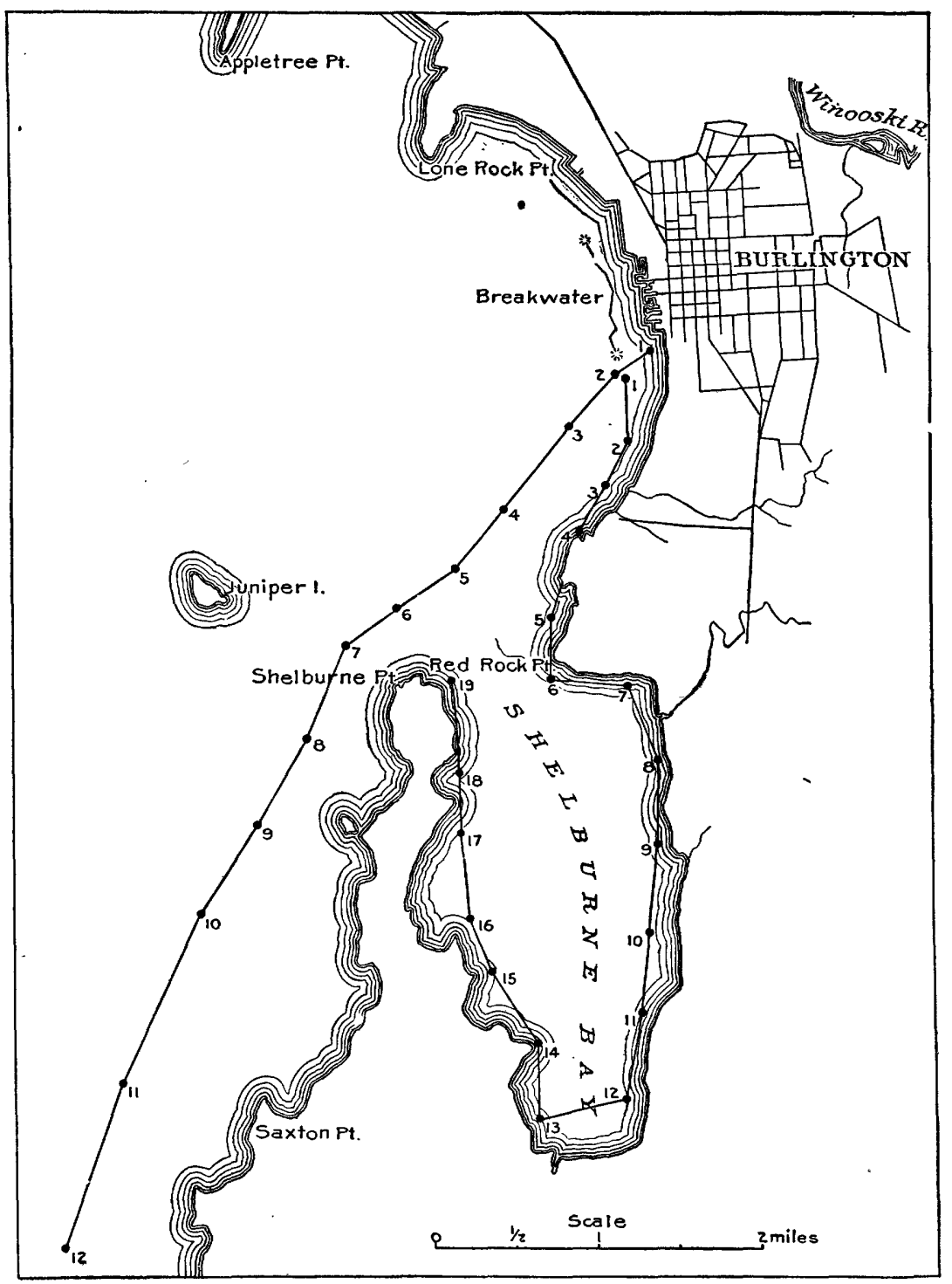

Fig. 4.-Burlington sample series of September 16 and 17. *

Burlington sample series of September 17, 1904.-A second series of samples involving sinilar determinations was taken on September 17, the course running south from Burlington along the shore for 7 miles to a point a short distance north of Quaker Smith Reef. This series consisted of 12 samples distributed along the line shown in fig. 4. The 
following are the results of the determinations made upon these samples:

Table XVIII.-Burlington pollution sample series of September 17, 1904.

\begin{tabular}{|c|c|c|c|c|}
\hline Sampling point. & $\begin{array}{l}\text { Total } \\
\text { solids. }\end{array}$ & $\begin{array}{l}\text { Volatile } \\
\text { solids. }\end{array}$ & $\begin{array}{l}\text { Per cent } \\
\text { volatile. }\end{array}$ & Chlorine. \\
\hline 1 & 66.0 & 24.0 & 36.4 & 1.2 \\
\hline $2 \ldots$ & 53.6 & 20.4 & 38.1 & 1.3 \\
\hline 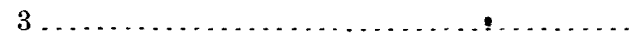 & 66.8 & 28.8 & 43.1 & 1.2 \\
\hline $4 \ldots$ & 62.4 & 24.8 & 39.7 & 1.1 \\
\hline $5 \ldots$ & 61.6 & 24.0 & 38.9 & 1.1 \\
\hline $6 \ldots \ldots \ldots$ & 60.8 & 17.6 & 29.0 & 1.1 \\
\hline $7 \ldots \ldots \ldots$ & 65.6 & 25.2 & 38.4 & 1.0 \\
\hline $8 \ldots \ldots$. & 66.8 & 22.8 & 34.1 & 1. 2 \\
\hline $9 \ldots \ldots$ & 79.6 & 24.0 & 30.2 & 1.3 \\
\hline $10 \ldots \ldots \ldots$. & 74.8 & 32.0 & 42.8 & .9 \\
\hline $11, \ldots \ldots \ldots, \ldots$ & 63.2 & 27.2 & 43.0 & .9 \\
\hline 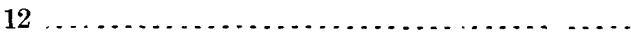 & 70.0 & 30.0 & 42.8 & 1.0 \\
\hline
\end{tabular}

The series of samples set forth in the above table affords results of little practical value save to show that at the lower end of the line, in the region of Quaker Smith Reef, the water is normal. Theie is no increase in per cent of volatile solids commensurate with the conditions as they might be supposed to exist in those stations, and in connection with the series of September 16 the conclusion must be drawn that the determination of volatile solids is without value in connection with this investigation. The amount of organic matter imparted to the lake is immediately diluted to so large an extent that the relative variations in the diluted sewage are not sufficient to account for any important amount of variation in the character of the water from the mouth of the sewer out into the lake. It is true that in a broad sense the relative amounts of chlorine give results which indicate something of importance, but as specific determinations for the tracing of sewage in this region it must be admitted that they are exceptionally weak.

While the two previous series of samples show unmistakably that the water to the south of Burlington is polluted by sewage, there is not sufficient definition in the results to indicate even approximately the extent to which the sewage may be harmful in the lake.

Sample series of September 22, No. 1.-In the next series of samples, taken on September 22, it was determined to try the results of complete sanitary analyses, in order to show whether the evidence 
with reference to the amount and condition of the organic matter would afford any better indication of sewage contamination than did the determination of volatile solids and chlorine. The samples were taken mainly inside the breakwater and along a line extending to the

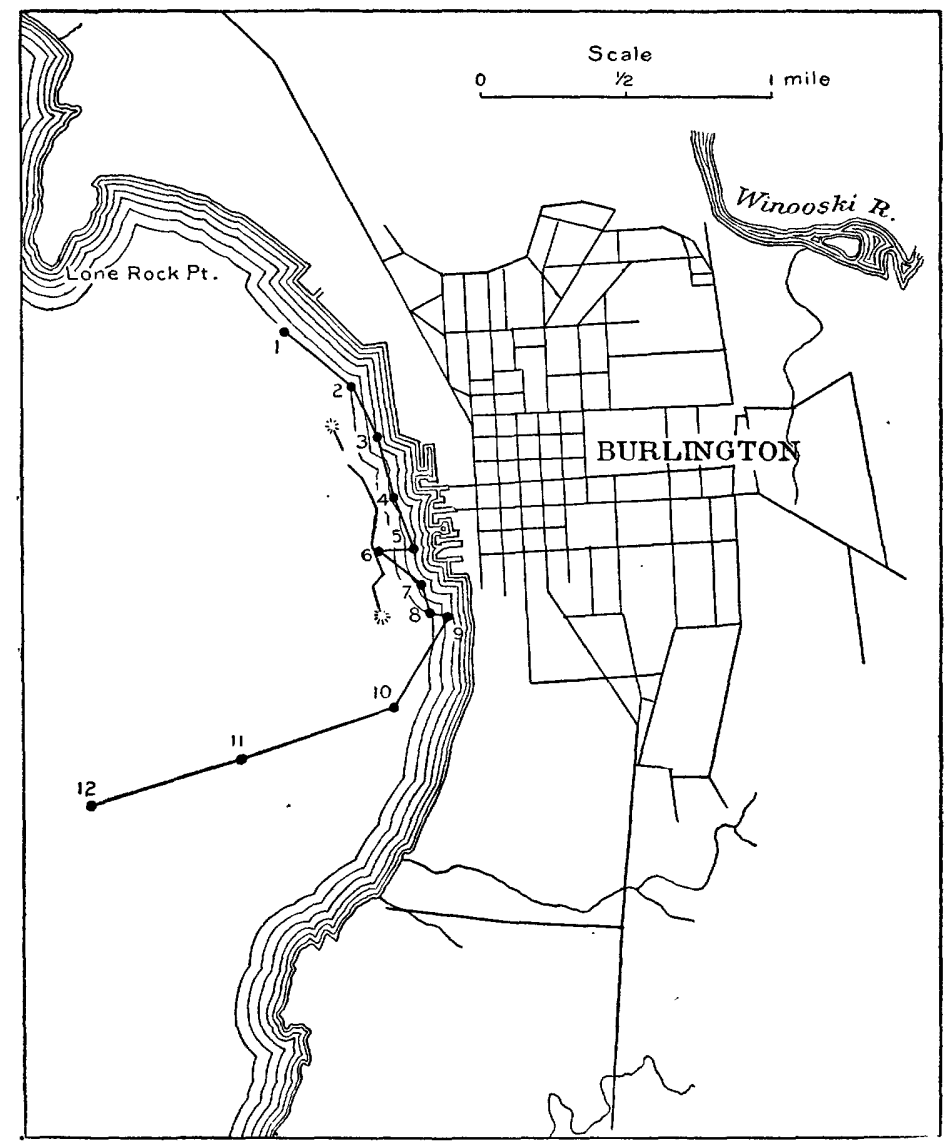

Fig. 5.-Burlington sample series of September 22, No. 1.

southwest, the direction thereof following that which was believed to be taken by the sewage from the outlet at Burlington (see fig. 5).

The results of the analyses, together with the determination of the number of bacteria and the nresence of Bacillus coli communis, are included in Table XIX. 
TABLE XIX.—Sanitary analyses in sample series of September $2 \mathbb{Q}$, No. 1.

[Parts per million.]

\begin{tabular}{|c|c|c|c|c|c|c|c|c|c|c|c|c|c|c|}
\hline \multirow[b]{2}{*}{ 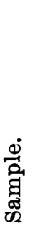 } & \multirow[b]{2}{*}{ Turbidity. } & \multirow[b]{2}{*}{$\begin{array}{l}0 \\
0 \\
0\end{array}$} & \multirow[b]{2}{*}{ 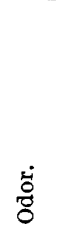 } & \multicolumn{4}{|c|}{ Nitrogen as- } & \multirow[b]{2}{*}{$\begin{array}{l}\text { 离 } \\
\text { 总 }\end{array}$} & \multirow[b]{2}{*}{ 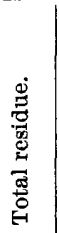 } & \multirow[b]{2}{*}{ 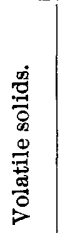 } & \multirow[b]{2}{*}{ 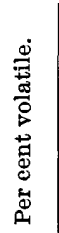 } & \multirow[b]{2}{*}{ 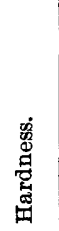 } & \multirow[b]{2}{*}{ 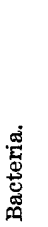 } & \multirow[b]{2}{*}{ 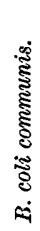 } \\
\hline & & & & 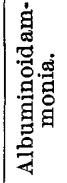 & 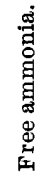 & 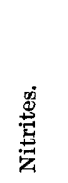 & 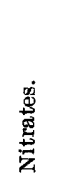 & & & & & & & \\
\hline 1 & Distinct... & 15 & $1 \mathrm{~V}$. & 0.132 & 0.006 & 0.000 & 0.160 & 1.0 & 69.0 & 17.0 & 24.6 & 51.4 & 400 & + \\
\hline 2 & ......do ..... & 15 & $1 \mathrm{E}$. & $\mid .128$ & .014 & .000 & .180 & 1.0 & 71.0 & 20.0 & 28.2 & 51.4 & 640 & + \\
\hline 3 & ......do ..... & 13 & $1 \mathrm{v}$. & .116 & .004 & .000 & .170 & .9 & 68.5 & 19.0 & 27.7 & 50.0 & 200 & + \\
\hline 4 & ......do..... & 13 & $1 \mathrm{E}$. & .112 & .002 & .000 & .160 & .9 & 71.5 & 19.5 & 27.0 & 51.4 & 640 & + \\
\hline 5 & ......do..... & 13 & $2 \mathrm{~A}$. & .120 & .006 & .000 & .170 & .9 & 69.5 & 19.5 & 28.1 & 50.0 & 300 & + \\
\hline 6 & ...... do ..... & 15 & $1 \mathrm{~A}$. & .204 & .016 & .000 & .190 & .9 & 72.0 & 20.0 & 27.6 & 51.4 & 610 & + \\
\hline 7 & .....do.... & 8 & $2 \mathrm{~A}$. & .106 & .002 & .000 & .160 & .9 & 66.5 & 16.0 & 24.1 & 50.0 & 300 & + \\
\hline 8 & ......do .... & 8 & $1 \mathrm{~A}$. & .142 & .026 & .000 & .160 & .9 & 66.5 & 13.5 & 20.3 & 51.4 & 680 & + \\
\hline 9 & ......do ..... & 13 & $1 \mathrm{~A}$. & .130 & .012 & .000 & .160 & .9 & 69.0 & 20.0 & 29.0 & 48.6 & 780 & + \\
\hline 10 & $\ldots$...do $\ldots$. & 8 & $1 \mathrm{~A}$. & .136 & .008 & .000 & .170 & .8 & 72.0 & 22.0 & 30.6 & 50.0 & 500 & + \\
\hline 11 & ......do..... & 14 & $1 \mathrm{~A}$. & .138 & .008 & .000 & .170 & .9 & 69.5 & 20.5 & 29.5 & 48.6 & 920 & t. \\
\hline 12 & ......do ..... & 9 & $1 \mathrm{~A}$. & .134 & .014 & .000 & .170 & .9 & 71.0 & 20.0 & 28.2 & 51.4 & 680 & + \\
\hline
\end{tabular}

In considering the results set forth in Table XIX it will be of interest first to compare, so far as the material admits of comparison, the conditions existing in the water at the present time with those indicated in previous pages, Tables XV and XVI. It will be noted that in Table XV certain determinations were given with reference to the water from the lake at the mouth of the suction pipe, as then situated at the northern extremity of the Burlington docks. With the first 6 determinations a fair comparison can be made with the results of sample 2, Table XIX. The sample was taken a short distance west of the dock at which the intake pipe was formerly situated. It will be seen at once that the amounts of free and albuminoid ammonia expressed in both tables are not materially different. Some of the determinations in the earlier series show greater amounts of these two constituents than were shown in sample 2 in the table above. Therefore these two determinations can not be accepted as indicative of any comparative amounts of pollution.

In the fifth and sixth determinations of the earlier series it will be noted that the amounts of total solids are not materially different, but the analysis of September, 1904, shows a considerable increase in volatile material over the determination made by Seeley in March, 1885 . This relative difference disappears, however, when the determination of Hills, made January 8,1889 , is taken into consideration. The per cent of volatile solids, therefore, does not indicate an absolute increase in the amount of organic matter. Indeed, the determinations here considered are not well fitted to show the facts desired. The amount of organic matter varies from day to day, and these fluctua- 
tions are sufficient to vitiate any intelligent interpretations. There should be a large number, covering a considerable season, to afford a general survey or average which will be largely representative of actual conditions.

The amounts of chlorine set forth in the various determinations here compared offer no better information than do the determinations of organic matter. The two determinations which are of value in this work are those of Bacillus coli communis and the number of bacteria per cubic centimeter. This determination does not appear in the earlier analyses, but in those of September, 1904, it is shown that the number of bacteria is large and that there is undoubted indication of intestinal pollution.

The determinations made by Sabin and by Witthaus in September, 1884, of samples taken from the surface midway between the sewer mouth and the south end of the breakwater, may be fairly compared with samples 7 and 8 in Table XIX. The only information recorded in the earlier determinations is that with reference to total and volatile solids, free and albuminoid ammonia, and chlorine. The total solids in the later determinations, as well as the chlorine, are considerably lower than those made in 1884. The amount of chlorine in the determination made by Witthaus is enormous, while the amount of total solids in both of the earlier samples is sufficiently high to confirm the chlorine determination. On the other hand, it is shown that the chlorine in the water taken during the recent investigation is below that determined as the normal for the broad lake. The determination is certainly anomalous, is not borne out by the facts known to exist, and is unworthy of confidence. To offset this the bacteriological determinations show clearly the presence of Bacillus coli communis, and, in the case of sample 8, of a high number of bacteria per cubic centimeter.

Comparing the analysis of sample 2 in Table XIX with that of the lake water at the old intake, in Table XVI, it will be seen that while the total solids in the later sample are considerably higher than those in the earlier, the amount of volatile matter is 60 per cent greater. The amounts of free and albuminoid ammonia are not significant in this comparison. While the nitrates are considerably higher in the later determination, chlorine is found to be somewhat lower in Table XVI. On the whole the comparison assists very little in arriving at any decision with reference to the amount of pollution in the lake at the dates of the determinations. Throughout the entire period of investigation, from 1889 to the present time, chemical evidence in relation to the effect of Burlington sewage upon Lake Champlain is of little value, and in many respects is misleading to a dangerous degree.

It will now be in order to contrast the determinations recorded in the above table with those which were made with the sample series of SepIRR $121-05-6$ 
tember 16 and 17, and to show, if possible, whether the additional data contained in the later series with reference to the amount and condition of organic matter give any more evidence concerning the pollution of the lake than do the determinations of total and volatile solids, which were found to be of practically no value in the earlier series.

In the foregoing discussion of the results of September, 1904, compared with those taken from 1885 to 1892 , it was shown that there is no significant difference in the various determinations, and that in both series of samples the chemical evidence was of no value in determining the actual effect of Burlington sewage on the lake. A little consideration will result in the same conclusions with reference to the series set forth in Table XIX. There is no logical variation in the amount of albuminoid ammonia, the sample taken directly in front of the sewer outlet showing not as much organic matter in any of the various forms determined as that taken at more distant points, where the effects of pollution must necessarily be less. So far as the general evidence contained in the table goes, it throws no light upon the problem in hand, and the entire interpretation must be based upon the number of bacteria per cubic centimeter and the presence of intestinal bacteria. The following is a statement by Dr. B. H. Stone, director of the State laboratory of hygiene at Burlington, Vt., who conducted the biological investigations with reference to the methods employed to isolate the Bacillus coli communis.

(a) A fermentation tube filled with a 2 per cent faintly acid lactose bouillon, to which has been added 1 per cent of one-half of 1 per cent aqueous solution of neutral red, is inoculated with 5 cubic centimeters of the water to be examined, or 5 tubes are inoculated with 1 cubic centimeter each. If no gas is found after an incubation period of twenty-four hours at $37^{\circ} \mathrm{C}$. the absence of the colon bacillus is shown.

(b) If from 25 to 70 per cent of gas is formed in the closed arm, a tube containing 10 cubic centimeters of neutral broth, to which has been added 0.3 cubic centimeter of Parietti's solution, is inoculated with one-half cubic centimeter of the contents of (a) and incubated twenty-four hours at $37^{\circ} \mathrm{C}$.

(c) A second fermentation tube is now inoculated with one-half cubic centimeter of the contents of $(b)$ and grown twenty-five hours at $37^{\circ} \mathrm{C}$. If there is no gas we may be sure the gas producer in $(a)$ was not the colon bacillus. If, on the other hand, 25 to 70 per cent of gas is produced in this tube with the characteristic neutral red yellow-red reaction (the fluid in the open arm remaining red while the closed arm shows a beautiful fluorescent yellow with a sharp line of demarcation betweenStokes) we may be reasonably sure that the colon bacillus is present.

(d) Further confirmation is obtained by ascertaining the gas formula from (c). The formula for the colon bacillus is $\mathrm{H}: \mathrm{CO}_{2}=2: 1$.

The tests for Bacillus coli communis noted in the foregoing statement were presumptive, and under ordinary conditions could in no wise be accepted as conclusive evidence of the presence of that organism. In the interpretation of results there must arise a question as to the value of presumptive tests. The general opinion among water bacteriologists is that such tests may indicate this organism, but that 
it is necessary to resort to additional methods of identification where there is any doubt with reference to the presence of sewage. It should be remembered, however, that in the present case presumptive tests were made in water in which the presence of sewage had been clearly established. In justifying their use it must be admitted that the question of presence of the sewage organism is not involved. The large volumes of sewage pouring into the lake from the trunk sewer settle the question so far as mere presence of Bacillus coli is concerned. Years of research have demonstrated that this organism must be present under such conditions. The problem, then, is merely to determine the area of influence of these organisms. Numerous presumptive tests made upon the water of the broad lake failed to give positive results in a single instance; therefore, taking into consideration the fact of negative evidence in the broad lake and positive evidence in the area known to be polluted, the presumptive tests are undoubtedly safe and certain in tracing the extent of sewage pollution.

Considering only the bacteriological evidence set forth in the results in Table XIX, it will be noted that throughout the course covered by the series the number of bacteria per cubic centimeter is large and that the presence of the colon group indicates undoubted evidence of intestinal bacteria. At sampling point No. 12, situated at a distance of about 2 miles from the outlet sewer, in a southwesterly direction, the number of bacteria is extremely high considering the distance, and the Bacillus coli communis still persists.

It has been shown by the series of September 16 that south of the city and in Shelburne Bay there are undoubted evidences of pollution. The series of September 17 indicates that this pollution does not extend as far south in the lake proper as Quaker Smith Reef. The series of September 22, the results of which are set forth in Table XIX, show conclusively that the inner harbor of Burlington is polluted and that the condition can be traced for a considerable distance to the southwest in a broad, sweeping curve, following the course which, from various observations, was determined to be one of those followed by the Burlington sewage.

Sample series of September 22, Nos. 2 and 3.-On the same day, September 22, two other series of samples were taken (fig. 6). The first extended from the foot of Maple street past the outlet sewer, turning around the south end of the breakwater in a sharp curve, and extending northward toward Appletree Point for a distance about equal to the length of the breakwater. The second extended from the shore opposite the railroad depot along a straight line, passing close to the north end of the breakwater and thence to Lone Rock Point. The object of these samples was to show to how great an extent northwestward from the city the intestinal bacteria might be traced, and. especially to determine whether the regions immediately outside the breakwater were affected. 
The result of the first series set forth in Table XX refer to the samples taken along the course extending from Maple Tree dock to point No. 7, opposite the rift in the breakwater, as shown in fig. 6 .

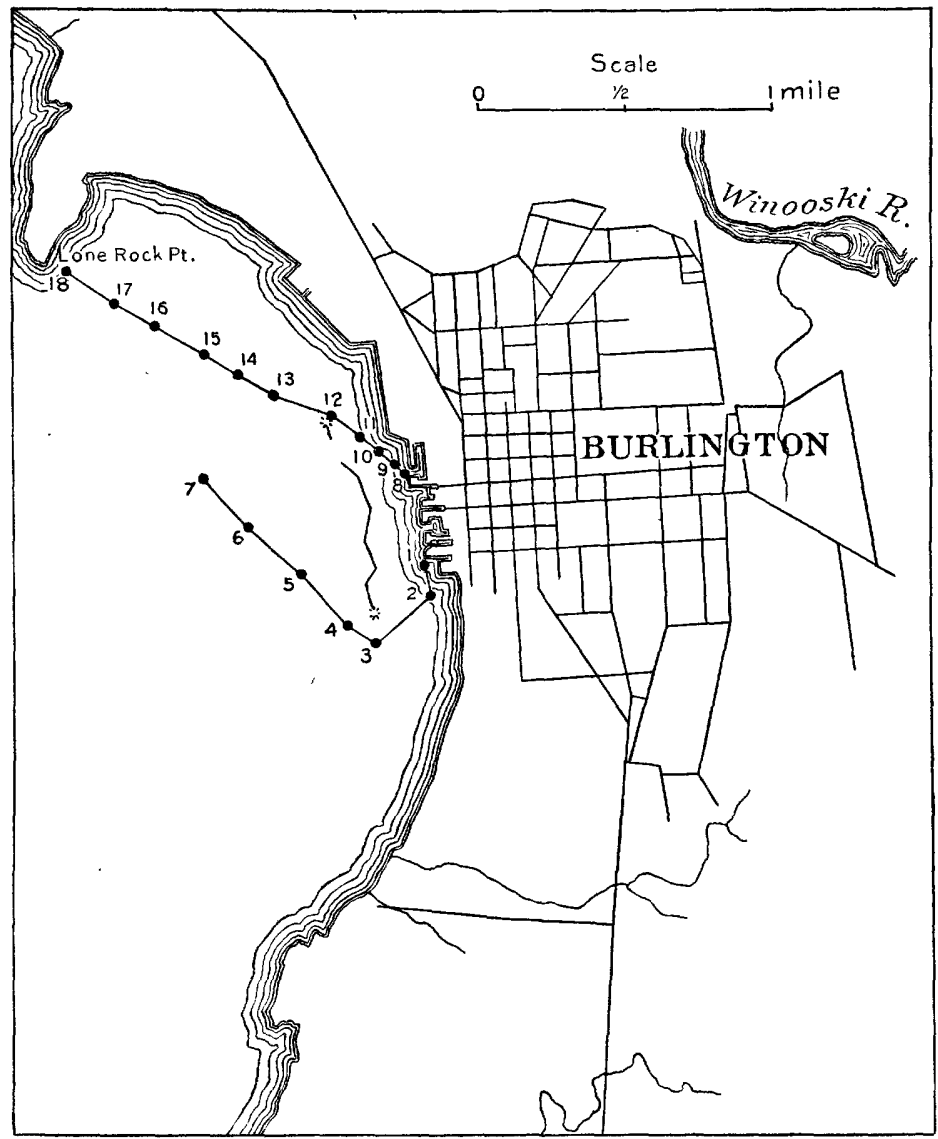

FIG. 6.-Burlington sample series of September 22, Nos. 2 and 3.

TaBuE XX.-Burlington sewage sample series of November 22, 1904, No. 2.

Sampling point.

\begin{tabular}{r|r|c} 
Chlorine. & $\begin{array}{c}\text { Bacteria per } \\
\text { cubic } \\
\text { centimeter. }\end{array}$ & $\begin{array}{r}\text { B. coli com- } \\
\text { munis. }\end{array}$ \\
\hline 1.1 & 250 & Present. \\
1.4 & 300 & Do. \\
1.4 & 300 & Do. \\
1.3 & 550 & Do. \\
1.3 & 300 & Do. \\
1.1 & 250 & Do. \\
1.0 & 300 & Do.
\end{tabular}


The results of this series show a general contamination along the course upon which the samples were located. The amount of chlorine is abnormally high at the sampling points inside and to the south of the breakwater, while at points 6 and 7 evidence of pollution disappears, so far as the chlorine is concerned. The number of bacteria, too, upon comparison with the preceding series, shows that the water close outside the breakwater contains less organic matter than that in series No. 1 for September 22. This indicates that the greater part of the sewage takes a broader sweep to the south and west than the course followed in this series. The fact that intestinal bacteria were present in all samples is, however, the best evidence concerning the condition of the lake. Sewage pollution is undoubtedly present.

The third series of samples, extending northwestward from the city to Lone Rock Point, gave the following results:

TABLE XXI.-Burlington sewage sample series of September 22, 1904, No. 3.

\begin{tabular}{|c|c|c|c|}
\hline Sampling point. & Chlorine. & $\begin{array}{c}\text { Bacteria per } \\
\text { cubic } \\
\text { centimeter. }\end{array}$ & $\begin{array}{l}\text { B. coli com- } \\
\text { munis. }\end{array}$ \\
\hline $8 \ldots$ & 1.4 & 250 & Present. \\
\hline $9 \ldots \ldots$ & 1.3 & 150 & Do. \\
\hline $10 \ldots \ldots . . . .$. & 1.3 & 150 & Do. \\
\hline $11 \ldots \ldots \ldots$ & 1.4 & 250 & Do. \\
\hline $12 \ldots \ldots \ldots \ldots$ & 1.4 & 100 & Do. \\
\hline $13 \ldots$ & 1.1 & 100 & Do. \\
\hline $14 \ldots \ldots \ldots \ldots$ & 1.3 & 100 & Do. \\
\hline $15 \ldots \ldots \ldots \ldots$ & 1.0 & 50 & Do. \\
\hline $16 \ldots$ & 1.1 & 150 & Do. \\
\hline $17 \ldots \ldots \ldots$ & 1.2 & 100 & Do. \\
\hline $18 \ldots \ldots \ldots \ldots$ & 1.3 & 100 & Do. \\
\hline
\end{tabular}

The amount of chlorine in the samples examined in this series shows a generally polluted condition along the entire course; while the number of bacteria per cubic centimeter is not significant, the presence of colon bacteria in all samples repeats the testimony given in the first and second sample series.

Burlington and Winooski sample series of September 25, 1904.-The next and final series of samples taken with reference to the sewage of Burlington also included observations concerning the effect of Winooski River. Before taking up the series, however, a few observations nust be made concerning Winooski River above Fort Ethan Allen and below the village of Winooski. In Table XXII are the results of sanitary analyses of the water from both of these points. The data show conclusively that the river above the fort still retains the evidences of pollution which it has received at its source. This evidence is not con- 
tained in the determination of the amount and condition of organic matter, but is plainly shown in the results of the bacteriological examination. Six hundred bacteria per cubic centimeter is probably somewhat higher than should be present in the river, while the presence of the colon bacillus gives undoubted evidence of intestinal pollution. The sample taken below Winooski shows an undoubted increase in the number of bacteria, colon being again present. It is but a short distance from Winooski to the mouth of the river, and the water discharged into the lake is without doubt in a condition represented by the second analytical statement in the table.

TABLE XXII.-Sanitary analyses of Winooski River water above Fort Ethan Allen and below Winooski village.

[Parts per million.]

\begin{tabular}{|c|c|c|c|c|c|c|c|c|c|c|c|c|c|}
\hline \multirow[b]{2}{*}{ Source of sample. } & \multirow[b]{2}{*}{ Turbidity. } & \multirow[b]{2}{*}{$\begin{array}{l}\text { : } \\
0 \\
0\end{array}$} & \multirow[b]{2}{*}{ Odor. } & \multicolumn{4}{|c|}{ Nitrogen as- } & \multirow[b]{2}{*}{ 离 } & \multirow[b]{2}{*}{ 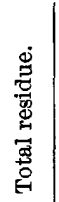 } & \multirow{2}{*}{ 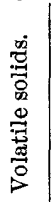 } & \multirow{2}{*}{ 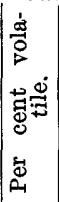 } & \multirow[b]{2}{*}{ 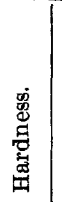 } & \multirow[b]{2}{*}{ 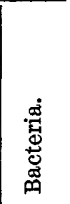 } \\
\hline & & & & 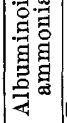 & 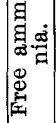 & 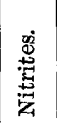 & 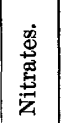 & & & & & & \\
\hline $\begin{array}{l}\text { WinooskiRiver above } \\
\text { Fort Ethan Allen. } a\end{array}$ & Distinct .. & 25 & $\begin{array}{l}\text { Distinet } \\
\text { earthy. }\end{array}$ & 0.106 & s. .014 & 0.000 & $|0.070|$ & 1.2 & 80.0 & 13.0 & 16.3 & 62.9 & 600 \\
\hline $\begin{array}{l}\text { Winooski River be- } \\
\text { low village.a }\end{array}$ & ..... do .... & 30 & ......do..... & .144 & 4.040 & .000 & .110 & 1.4 & 83.0 & 16.0 & 19.3 & 61.4 & 4,400 \\
\hline
\end{tabular}

a B. coli present.

The course followed in taking the samples of September 25 is indicated in fig. 7. The center was chosen at the mouth of Winooski River, and from there three lines were extended-one to the northwest toward Colchester Point, another due west, and a third southwest, swinging around Appletree Point to Appletree Shoal, and ending in a broad curve around the southern end of Burlington breakwater at the outfall sewer of the city. The results of analyses taken at the points chosen serve to show the extent of pollution from Winooski River, and the southerly line, designated line $\mathrm{A}$, is designed to give information concerning any continuity in the generally polluted condition which exists between the mouth of Winooski River and the outfall sewer of Burlington. The determinations of value in such a series consist of the number of bacteria per cubic centimeter and the presence of Bacillus coli communis. By reason of unfortunate circumstances it was impossible to secure more than the results of the determination of the presence of intestinal bacteria, but the evidence brought out by this determination is so clear and convincing that it is believed that the omission does not weaken in any way the evidence presented. The results of the series of samples taken are shown in 
Table XXIII. The samples along the $\mathrm{B}$ and $\mathrm{C}$ lines were taken at distances of about one-half mile, extending from the center, while along the A line the intervals chosen were considerably shorter-from about one-fourth to one-third mile-located according to observed con-

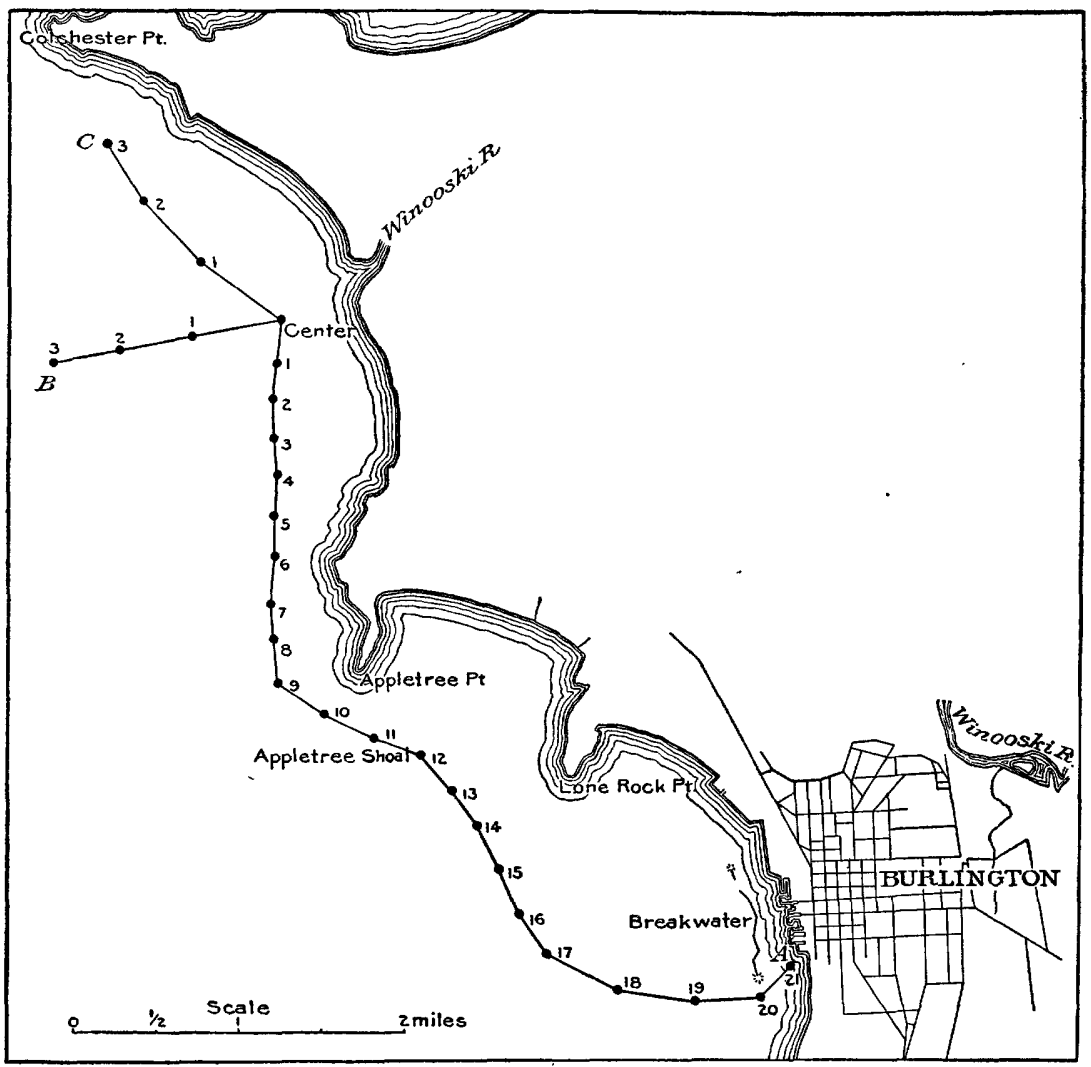

FIG. 7.-Burlington and Winooski sample series of September 25, 1904.

ditions of current and appearance of water, and fixed by intersecting lines running from various stationary points. It will be noted that sample 12 is at Appletree Shoal, directly over the mouth of the intake pipe. 
TABLE XXIII._Examination for Bacillus coli communis in sample series of September 25.

\begin{tabular}{|c|c|c|c|}
\hline \multicolumn{2}{|l|}{ C LINE. } & \multicolumn{2}{|l|}{ A LINE-Continued. } \\
\hline $\begin{array}{l}\text { Center } \ldots \ldots \ldots \ldots \\
1, \ldots \ldots \\
2 \\
3 \\
3\end{array}$ & $\begin{array}{l}\text { Present. } \\
\text { Do. } \\
\text { Do. } \\
\text { Do. }\end{array}$ & 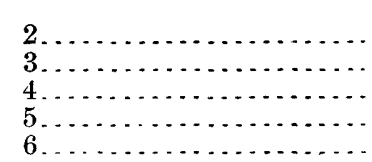 & $\begin{array}{l}\text { Present. } \\
\text { Do. } \\
\text { Do. } \\
\text { Do. } \\
\text { Do. }\end{array}$ \\
\hline \multicolumn{2}{|l|}{ B LINE. } & $\begin{array}{l}8 \\
9\end{array}$ & $\begin{array}{l}\text { Do. } \\
\text { Absent. }\end{array}$ \\
\hline $\begin{array}{l}\text { Center } \\
1 \ldots \ldots \\
2 \ldots \ldots \\
3 \ldots \ldots\end{array}$ & $\begin{array}{l}\text { Present. } \\
\text { Do. } \\
\text { Absent. } \\
\text { Do. }\end{array}$ & $\begin{array}{l}11 \\
12,1 \\
13 \\
14 \\
15\end{array}$ & $\begin{array}{l}\text { Do. } \\
\text { Do. } \\
\text { Do. } \\
\text { Do. } \\
\text { Absent. }\end{array}$ \\
\hline \multicolumn{2}{|l|}{ A LINE. } & 17 & $\begin{array}{l}\text { Do. } \\
\text { Present. }\end{array}$ \\
\hline $\begin{array}{l}\text { Center } \ldots \ldots \ldots . . . \\
1 \ldots \ldots \ldots\end{array}$ & $\begin{array}{l}\text { Present. } \\
\text { Do. }\end{array}$ & $20 \ldots \ldots \ldots \ldots \ldots$ & $\begin{array}{l}\text { Present. } \\
\text { Do. }\end{array}$ \\
\hline
\end{tabular}

The data in the above table show the presence of intestinal bacteria along the $\mathrm{C}$ line- that is, along a line practically parallel with the shore northwestward from the river. Along the $B$ line the bacteria were absent at the two outer sampling points. In other words, the conditions at these two points approach those of the normal broad lake. The A line is the interesting and important one, as it shows a practically continuous record of intestinal pollution from the mouth of the river until point No. 9 is reached, directly west of Appletree Point. This is an exposed position at which the purifying effect of dilution from the broad lake would be most likely to persist. The record further shows that intestinal bacteria were present at all sampling points and down to No. 15, which includes the sample taken at the mouth of the Burlington water-intake pipe. From points Nos. 15 to 17 , inclusive, no bacteria were noted, but at points Nos. 18, 20, and 21 they were again isolated. Abundant evidence of the presence of this germ in this region is also shown by the second and third sample series of September 22 .

\section{CONCLUSIONS.}

The data show clearly that the sewage of Burlington and from Winooski River pollutes practically the entire shore from Colchester Point to Shelburne Bay and includes within the contaminated area the water intake of the Burlington city supply. How much more extensive the effect of pollution from these two points may be, opportunity was not afforded to determine. The area included within the investigation is sufficiently large to indicate the general pollution of the 
water in this vicinity. In connection with the report on the early conditions of the Burlington water supply mentioned on pages $68-74$, it was shown that evidence concerning the persistence of sewage matter in the lake is particularly elusive and that the best method of identifying the unfavorable effects of Burlington sewage disposal was found to be in the improvement which was shown in the occurrence of intestinal diseases in the city. There has been no general inquiry with reference to the abnormal amount of so-called diarrhea in Burlington since the investigation made by Professor Sedgwick. Nevertheless, the typhoid records in that city are not such as to inspire confidence in the water supply. A report of the local board of health shows the following typhoid records:

Typhoid cases in Burlington, Vt., 1900-1904.

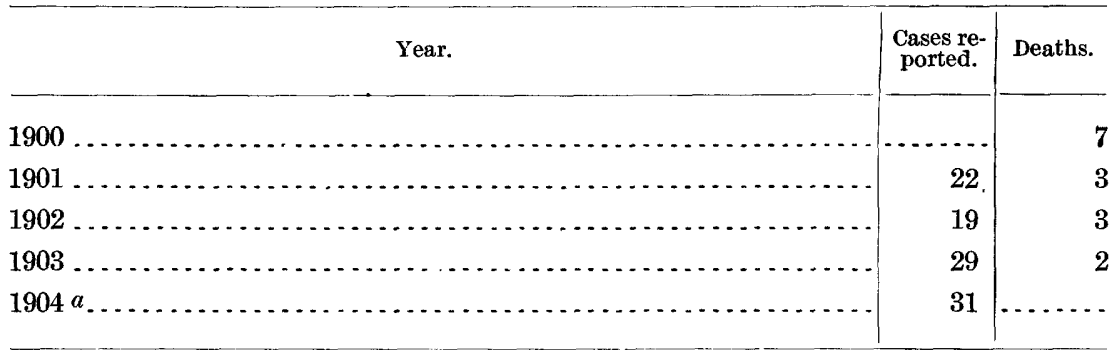

$a$ To November 25

The record of deaths from typhoid in the year 1904, up to November 25, was not available, and the report of the number of cases is probably not correct. Local officials state that many of the typhoid cases which have occurred during the year 1904 are not yet reported to the health officer, and that when the final returns are made the number stated above will be increased materially. Compared with the earlier conditions stated in the report of Professor Sedgwick, the present death rate from typhoid appears to be no greater, but, although the earlier morbidity statistics are not available, it is generally admitted by those conversant with the typhoid history of Burlington that the disease is more prevalent than formerly. Dr. B. H. Stone, director of the laboratory of hygiene at Burlington, has reported that 33 per cent of the daily samples of Burlington water taken from the laboratory tap during the month of November showed the presence of Bacillus coli communis. For each of these determinations only 1 cubic centimeter of the water was subject to examination.

Considering the results of the sample series stated in previous pages, the degree of prevalence of ty phoid fever in Burlington, and the results of examinations made at the State laboratory, it appears to be unquestionable that the sewage of Burlington and Winooski River is highly damaging to the lake in that vicinity. The area in which Bacillus coli 
communis was identified is much larger than that comprised in any of the other investigations where specific examination was made for evidences of pollution. Burlington is undoubtedly the source of the most serious contamination occurring in the lake.

\section{UPPER END OF LAKE CHAMPLAIN.}

\section{SODA-MILL AND SEWAGE POLLUTION.}

It has been explained that the investigation of the effect of wastes from the mill of the Ticonderoga Pulp and Paper Company must receive interpretation different from that involved in the three cases treated on previous pages. Wastes from the sulphite-pulp mill at Ausable Forks, from the soda-pulp mill at Willsboro, and from the city of Burlington and Winooski River discharge into the broad lake where the water is normally clear and of excellent physical appearance and where the volume of lake water affords excellent facilities for dilution and sedimentation.

That part of the lake into which the Ticonderoga pulp-mill pollution flows is narrow and shallow, affording far less opportunity for dilution and sedimentation than the broad lake. This condition would serve to make the identification of wastes less difficult than in the case of the first three investigations. On the other hand, such identification is rendered more difficult by reason of the fact that this part of the lake contains water far inferior to that of the broad lake. Bordered and underlain by clay, the water contains a greater amount of suspended material. The amount of this material, too, varies enormously. The water is profoundly stirred by high winds from certain directions, and large quantities of mud from the bottom and the banks are brought up and become suspended material. Thus the condition of the water is largely a reflection of the direction and violence of the wind. A second feature affecting the condition of the water is the amount of precipitation in the immediate drainage area surrounding it; after heavy rains large amounts of foreign matter in suspension are washed into the lake. These facts render the detection of pollution from the mill into the lake more complicated than it would be if the water were like that of the broad lake, and more than compensates for the advantages arising from the comparatively small volume of water into which the wastes are turned.

The soda process is used at the Ticonderoga mill, and therefore the special features of the investigation are similar to those reviewed in the case of the Willsboro mill. In the interpretation of results there are, however, modifying features other than those above mentioned as due to the peculiar characteristics of lake water. In the case of the Willsboro pollution it was demonstrated that only the wastes from the mill were to be considered, no sewage in perceptible amount 


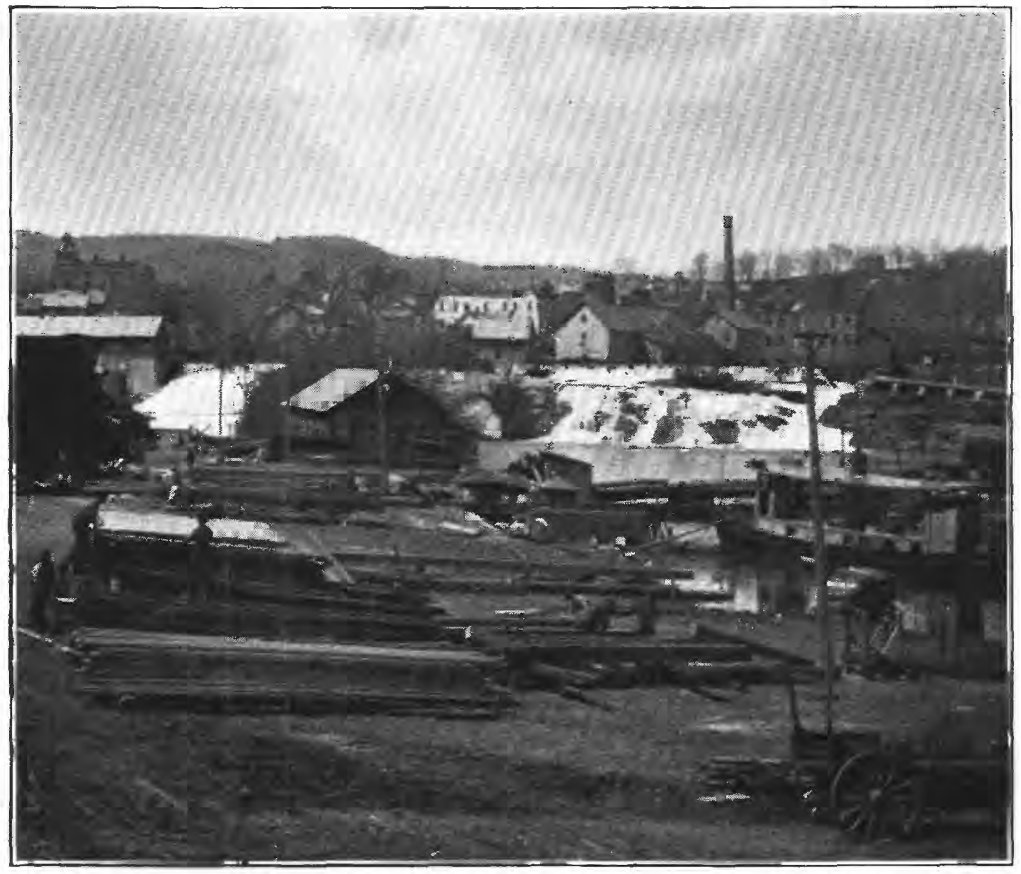

A. WATER POWER OF TICONDEROGA PULP AND PAPER COMPANY, TICONDEROGA, N. Y.

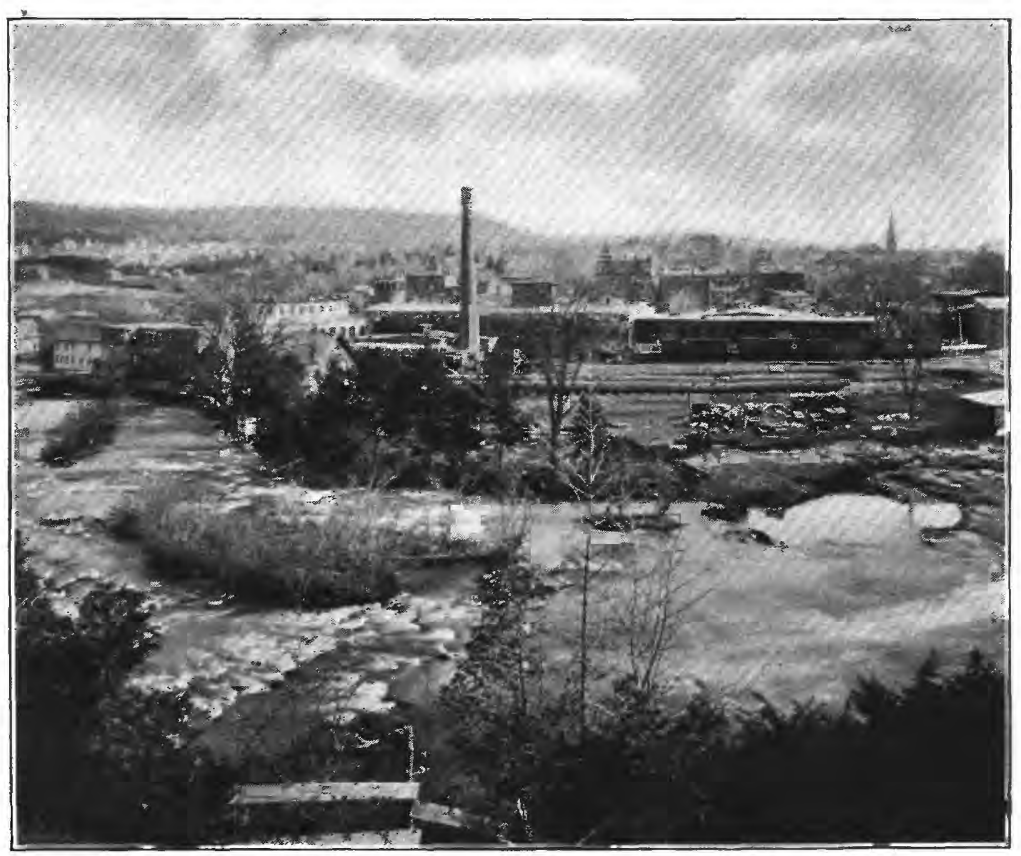

B. VIEW AT TICONDEROGA, N. Y. 
being demonstrated. In the present case, however, there is a complication which arises from the discharge of sewage from Ticonderoga village, which contains 1,911 inhabitants $(\mathrm{Pl}$. XI, $B$ ). There is also a considerable amount of ground wood which is wasted from the mechanical pulp mills situated on Ticonderoga Creek above the village (PI. XI, A). These wastes undoubtedly modify the effect of the mill waste and must be taken into consideration in interpreting the results of the analyses.

\section{CHARACTER OF UPPER-LAKE WATER.}

Before taking up the study of the character and effect of the polluting matter, it will be necessary to determine, as clearly as possible under the existing conditions, just what is the normal character of the water in this portion of the lake, so that some standard may be adopted with which the specific determinations made for the purpose of tracing the polluting matter may be compared. It will be seen, on examination of the conditions in this part of the lake, that the selection of a point at which a normal sample can be taken is rather difficult. At the head of the lake is the village of Whitehall, containing 4,377 inhabitants. The sewage from this place is discharged into the lake; therefore, at its very head the lake is polluted, and as the current flows northward there must be some effect upon that part of the lake in the region of Ticonderoga.

But the distance from Whitehall to Ticonderoga by lake is $22 \frac{1}{2}$ miles, and, as the rate of lake flow is slow, it is practically certain that the effects of sewage matter are largely if not entirely overcome in that distance. In fact, it may be stated with confidence that the only possible chemical evidence of Whitehall sewage in the lake above Ticonderoga Creek will be the slightly higher proportion of chlorine. Therefore a sample taken from such a point will represent practically the normal water of the lake, if the possibility of back flow from Ticonderoga Creek up the lake be eliminated. Bearing this in mind, a sample was taken one-half mile south of Chipmans Point (fig. 8, p. 101). The distance from 'Whitehall to this sampling point is 19 miles, and from the mouth of Ticonderoga Creek $3 \frac{1}{2}$ miles. The sample was taken on August 27, 1904. For several days prevailing winds had blown from the south, and at the time of sampling and for eighteen hours previous the wind from this direction had been uncommonly strong. This fact, together with the distance uplake from the mouth of the creek, makes it fairly certain that no Ticonderoga pollution was encountered. 
The results of analyses of this water are as follows:

TABLE XXIV.-Analysis of water from Lake Champlain one-half mile south of Chipmans Point.

[Parts per million.]

\begin{tabular}{|c|c|c|c|}
\hline \multicolumn{2}{|l|}{ Mineral. } & \multicolumn{2}{|l|}{ Sanitary. } \\
\hline $\mathrm{SiO}_{2} \ldots \ldots \ldots \ldots$ & 11.2 & Color $\ldots \ldots \ldots \ldots \ldots$ & 1.5 \\
\hline $\mathrm{Fe}_{2} \mathrm{O}_{3}+\mathrm{Al}_{2} \mathrm{O}_{3} \ldots \ldots \ldots \ldots$ & 4. 2 & Odor ................ & $2 \mathrm{E}$ \\
\hline $\mathrm{CaO} \ldots \ldots \ldots \ldots \ldots \ldots$ & 28.07 & Albuminoid ammonia.. & 0.116 \\
\hline $\mathrm{MgO} .$. & 9.79 & Free ammonia ....... & $0.02+$ \\
\hline $\mathrm{Na}_{2} \mathrm{O}$ & 4. 66 & Nitrites... . . . . & 0.000 \\
\hline $\mathrm{Cl} \ldots \ldots$ & 1.2 & Nitrates . & 0.030 \\
\hline $\mathrm{SO}_{3} \ldots \ldots \ldots \ldots \ldots \ldots$ & .24 .4 & Chlorine........ . & 1.200 \\
\hline \multirow[t]{2}{*}{$\mathrm{CO}_{2} \ldots \ldots \ldots$} & 21.93 & Total solids $a \ldots$ & 109.000 \\
\hline & 105.45 & Volatile solids .... & 25.0 \\
\hline \multirow{4}{*}{$\begin{array}{r}\text { O replaced by } \mathrm{Cl} \ldots \\
\text { Total solids } a\end{array}$} & .54 & Per cent volatile.. & 22.9 \\
\hline & 104.91 & Hardness.... & 80.0 \\
\hline & & Bacteria per cubic centimeter. & 1,200 \\
\hline & & B. coli communis .............. & Absent. \\
\hline
\end{tabular}

aThe difference in the amount of residue in the analyses is explained by the fact that samples for the mineral and the sanitary analysis were not taken at the same hour nor in exactly the same place.

The data set forth in the mineral analysis above show that the amounts of lime, magnesia, and silica are considerably larger than those determined in the water taken from the broad lake, while the sulphates exceed those previously determined by a still greater'proportion. It is important to note that the amount of soda in this part of the lake is lower than that shown in Table III. As soda is one of the principal constituents of the waste from the Ticonderoga mill, an increase in the amount of this substance in the lake in the region about the mouth of Ticonderoga Creek will be one of the most concise demonstrations possible concerning the effect of the waste. It should be borne in mind, however, that inasmuch as the calcium, largely in the form of calcium carbonate, is in high proportion in the water from this end of the lake, the alkalinity must be higher than that in the broad-lake water.

Considering the sanitary analysis above set forth, it will be seen that the amount of dissolved residue is considerably greater than that determined for the broad lake, while the proportion of volatile solids is smaller. This indicates that by far the greater proportion of the dissolved matter is inorganic. The degree of hardness which corresponds to the excess of calcium and magnesium noted in the mineral analyses is considerably higher than that noted in the broad-lake 


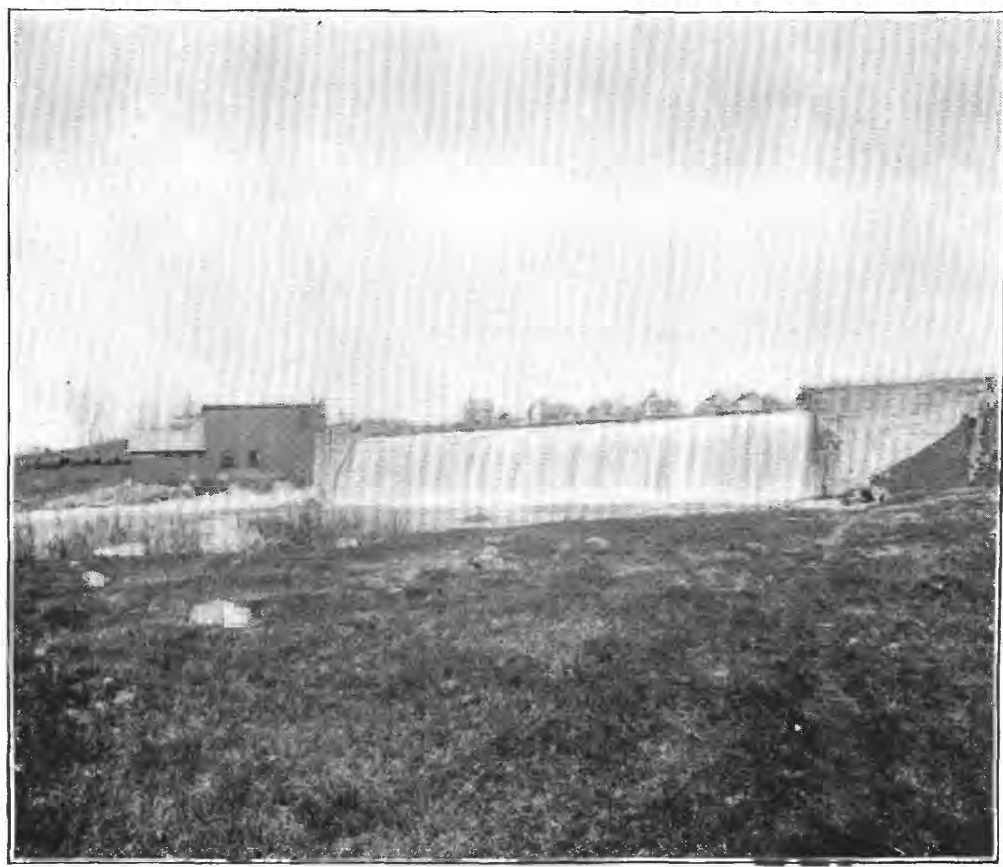

A

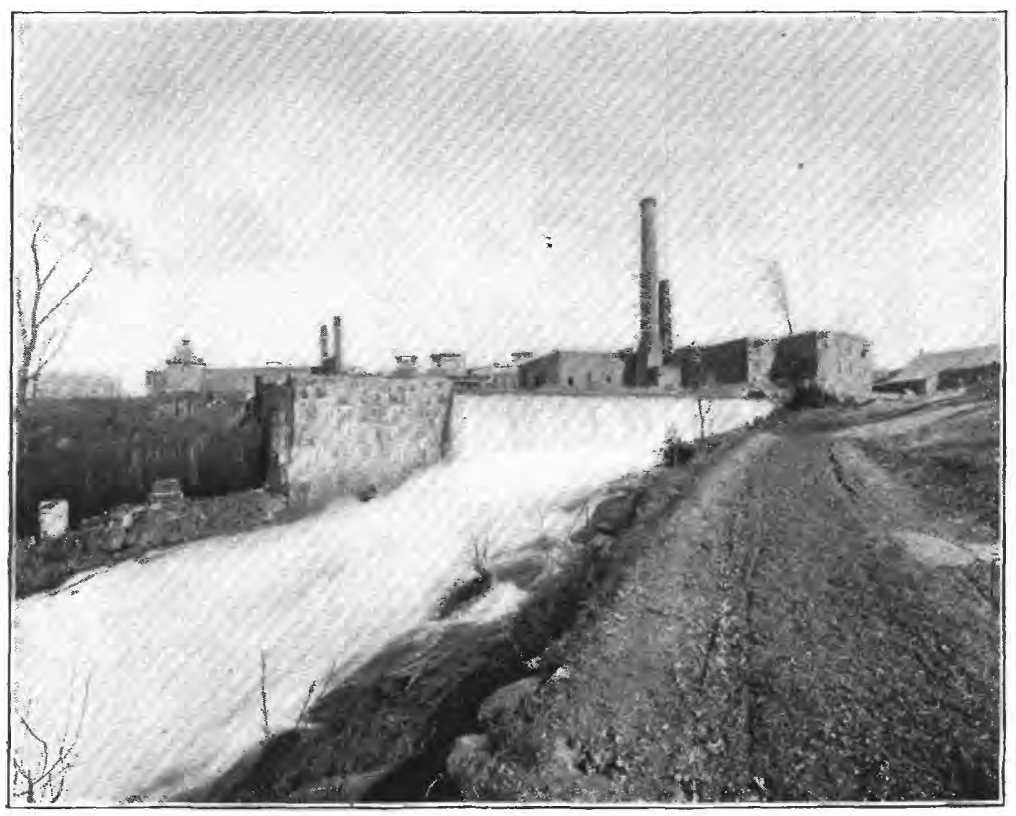

B

WATER POWER OF INTERNATIONAL PULP COMPANY, TICONDEROGA CREEK.

$A$, "A" mill; $B$, "B" mill. 
samples. It will be noted further that the number of bacteria per cubic centimeter in this part of the lake is high, while Bacillus coli communis is absent. The bacteria found in the sample are presumably not of sewage origin, but accompany the suspended matter in the water and have their origin in purely local and natural features.

\section{CHARACTER OF TICONDEROGA CREEK WATER ABOVE PULP MILL.}

The water in Ticonderoga Creek, as it emerges from Lake George, is clear and of excellent quality. It contains 10.63 parts per million of lime, 5.31 parts of magnesia, 5 parts of silica, and small proportions of iron, alumina, and soda. The sanitary analysis reveals no odor, a slight color, practically no turbidity, 37 parts per million of residue, 40 per cent of which is volatile, 0.09 parts of albuminoid ammonia, 0.008 parts of free ammonia, no nitrites, 0.04 parts of nitrates, and 0.05 parts of chlorine. The hardness is 26 parts per million, stated in terms of calcium carbonate.

A short distance below Lake George the creek passes two groundwood pulp mills (Pl. XII, $A$ and $B$ ), which formerly discharged considerable quantities of waste pulp into the water; improvements have been made recently. Upon reaching the upper limit of the village of Ticonderoga the creek passes over clay beds and immediately becomes turbid. This condition becomes more pronounced as the stream passes through the village to the headgates of the water power which operates the Ticonderoga pulp mill (Pl: XI, A). Here the water has an offensive appearance and odor, due to the refuse turned into the creek from the village (Pl. $\mathrm{XI}, B)$. This was found to be a convenient sampling point to determine the effects of sewage on the stream without the complications arising from the Ticonderoga mill waste, as all waste from this mill is turned into the stream some distance below. 
The following table contains the results of an analysis of the water at this point:

TABLE XXV.-Analysis of water from Ticonderoga Creek below Ticonderoga mill and above chemical pulp mill.

[Parts per million.]

\begin{tabular}{|c|c|c|c|}
\hline \multicolumn{2}{|l|}{ Mineral. } & \multicolumn{2}{|l|}{ Sanitary. } \\
\hline $\mathrm{SiO}_{2} \ldots \ldots \ldots \ldots \ldots \ldots$ & 6.0 & Total solids ......... & 56.0 \\
\hline $\mathrm{Fe}_{2} \mathrm{O}_{3}+\mathrm{A1}_{2} \mathrm{O}_{3} \ldots \ldots \ldots \ldots$ & 4.6 & Albuminoid ammonia ... & .086 \\
\hline $\mathrm{CaO} \ldots \ldots \ldots \ldots \ldots$ & 13.20 & Free ammonia ............ & .000 \\
\hline MgO.......... & 4.15 & Nitrites ........ & .000 \\
\hline $\mathrm{Na}_{2} \mathrm{O} \ldots \ldots \ldots \ldots \ldots \ldots$ & 3. 231 & Nitrates..... & .050 \\
\hline Cl $\ldots \ldots \ldots \ldots \ldots$ & 1.5 & Chlorine ........ & 1.5 \\
\hline $\mathrm{SO}_{3} \ldots \ldots$ & 4.4 & Hardness. . . . . . . . . . . . & 33.8 \\
\hline $\mathrm{CO}_{2} \ldots \ldots \ldots \ldots \ldots \ldots$ & 13.83 & Alkalinity ............... & 30.0 \\
\hline $\mathrm{O}$ replaced by $\mathrm{Cl}$ & $\begin{array}{r}50.91 \\
.69\end{array}$ & $\begin{array}{l}\text { Bacteria per cubic centimeter } \\
\text { B. coli communis } \ldots \ldots \ldots \ldots \\
\text { Turbidity } \ldots \ldots \ldots \ldots \ldots\end{array}$ & $\begin{array}{l}72,000 \\
\text { Present. } \\
(a)\end{array}$ \\
\hline Total ................ & 50.22 & & \\
\hline $\begin{array}{l}\text { Total solids, including } \\
\text { organic matter ....... }\end{array}$ & 55.8 & & \\
\hline
\end{tabular}

a Considerable.

The points to be noted in the above analysis are:

(1) The increase in the amount of lime over that shown in the water at the head of the creek, $1 \frac{1}{2}$ miles away. This is due largely to the wastes from the paper mill of the Ticonderoga Pulp and Paper Company just above. These wastes consist largely of water which is used in the beaters to wash and separate the pulp fibers, with a small amount of chalk.

(2) The considerable increase in chlorine over that at the head of the creek, undoubtedly due to Ticonderoga sewage.

(3) The increase in hardness corresponding in a measure to the increase in lime.

(4) The enormous number of bacteria and the presence of Bacillus coli communis, due to sewage.

(5) The high turbidity which results in part from the paper-mill waste above mentioned, but principally from the clay beds over which the creek runs as it enters the village of Ticonderoga.

\section{TICONDEROGA PULP AND PAPER COMPANY.}

The plant of this company is located upon the right bank of Lake George outlet near the eastern border of the village of Ticonderoga. It is composed of two parts, one of which is largely devoted to the 
manufacture of wood pulp from poplar wood by the soda process, while in the other paper manufacturing is exclusively carried on. From the former plant there are discharged the trade wastes usually occurring in this process, while from the latter plant the only waste consists of large volumes of wash water contaminated to a very slight degree by chalk and the negligible amount of chemicals which seem inevitable in pulp after it has been submitted to the usual washing processes in the pulp mills. A large part of the water, however, which is discharged from this paper mill is practically pure, it being used merely to bring the pulp to such a fluid state that it can readily be handled in pipes and wet machines by pumps or gravity. So far as the question of water pollution is concerned, the main interest in the plant belonging to the Ticonderoga Pulp and Paper Company is centered in the pulp mill (PI. XIII, $B$ ).

\section{MANUFACTURE OF THE PULP.}

The method of manufacturing pulp by the soda process has already been described (see pp. 24-33) in connection with the discussion of the effect of the mills of the New York and Pennsylvania Company at Willsboro upon Bouquet River and Lake Champlain. Save for a few minor details in the process of treating the digested pulp, the description there given is sufficient for present purposes. The variations in the process of washing the crude pulp are, however, sufficiently broad to make it advisable to consider them briefly, in order that any differences which may appear in the effluents of the two mills may be explained.

The process of washing the crude pulp at Ticonderoga differs from that at Willsboro in that there is no use of waters containing weak solutions from previous washings. As soon as the wash pan is filled from the blowpit, the valve at the bottom of the pan is opened and the liquid contents are pumped directly to the soda-recovery plant. Simultaneously a stream of fresh, clear water is turned into the top of the pan. Thus as fast as the contents are drawn off at the bottom uncontaminated water takes their place at the top, and as the strong soda liquor is drawn lower and lower the fresh water progresses farther into the depths of the tank, there being a fairly strong demarcation between the original strong liquor and the wash water. The end of the washing is noted when the original soda liquor is entirely withdrawn from the pan and the wash water appears at the lower valve. Theoretically the contents of the pan are then pumped in the usual way to go through the more advanced stages of the process; practically this is not accomplished. Large quantities of wash water containing soda are diverted from the pipe leading to the soda-recovery plant and discharged into the tailrace of the mill, and thence find their way into the creek. The concentration of this solution is not high, and varies from time to time. Nevertheless, the total amount 
lost in the course of a year must be considerable, and, in addition, it adds to the burden of the stream. In order to secure some idea of the amount of soda lost in this way, four samples of this liquor were collected from one of the vats during the period of the washing. The first was taken at the time the wash water was first turned into the mill race, and the second, third, and fourth were collected thirty minutes, one hour, and one and one-half hours later, respectively. The amounts of soda in these samples were then determined and found to be as follows: No. 1, 960 parts per million; No. 2, 720 parts; No. 3, 528 parts; and No. 4, 424 parts. The flow of this liquor into the creek continued for a considerable time after taking the last sample, or probably a total period from start to finish of two hours. No records of the amount of liquor so discharged were obtainable, but it will readily be understood that, although the individual samples do not reveal any commercially great amount of soda, the constant flow from at least one of the 8 wash pans installed in this plant, each provided with 2-inch outlet pipes, must finally result in a large loss of soda and a corresponding increase in stream pollution. Whether this increase has any practical deleterious effect remains to be seen, but the facts must be noted in connection with the investigation. A part of this liquid waste which is conducted into the tailrace of the mill consists of organic extractives of the wood. In the case of the Willsboro mill it was noted that no organic matter entered into the pollution question. This can not be said with reference to the waste from the Ticonderoga mill. At the beginning of the diversion of this liquor into the tailrace the color is high, indicating a considerable amount of organic matter, which upon examination was found to be present. In comparison with the sewage which is turned into the stream from the village of Ticonderoga the total amount of the organic matter thus emptied into the tailrace is probably very, small. Nevertheless, its presence must be recognized in determining whatever effect there may be upon the lake by reason of the operation of this mill.

SEDIMENTATION BED.

Across the river from the mill is a sedimentation bed covering about 15 acres (Pl. XIII, $A$ ), into which the lime sludges from the causticizing and bleach-liquor plants and the black-ash sludge from the recovery plants are turned. This sedimentation bed does not differ materially from that at Willsboro. Its function is merely to separate the solid from the liquid effluent and allow the latter to pass into the river unchanged except by those variable, natural, and indefinite processes which are eommonly recognized in such cases.

This sedimentation bed is situated on the site of what was formerly a low, swampy piece of ground, and at the present time the level has been raised to a height of about 12 feet. From the standpoint of 


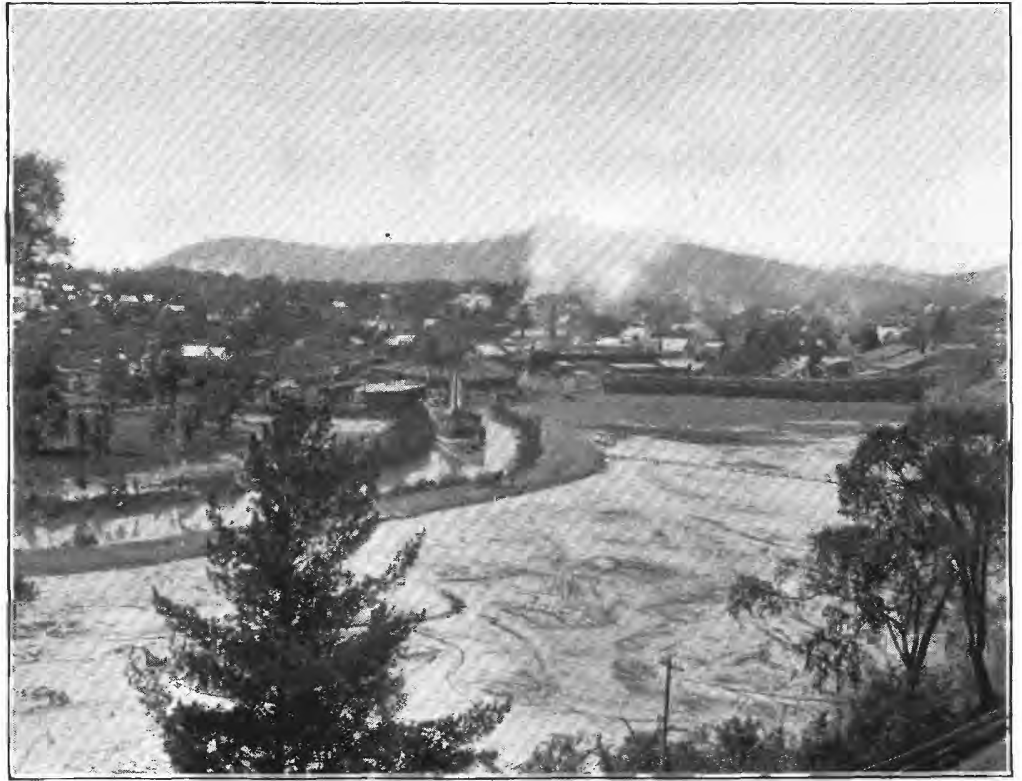

A. SEDIMENTATION BED OF TICONDEROGA PULP AND PAPER COMPANY,

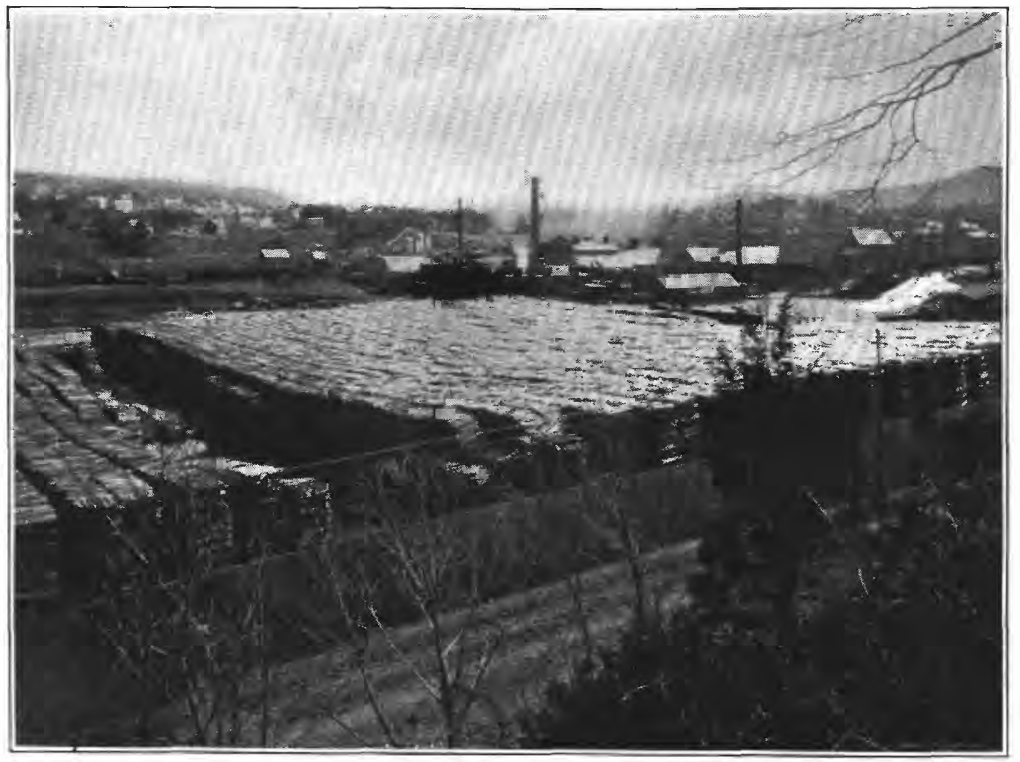

B. MILLS OF TICONDEROGA PULP AND PAPER COMPANY. 
effectiveness it probably performs the work expected of it, and there has never been any suggestion that during freshets in the spring the contents were washed into the lake. From the standpoint of an efficient sedimentation bed, planned and operated according to scientific principles, it does not in anywise fulfill the requirements. These objections are not of public concern. The disadvantages arising from them are solely those of lack of economy on the part of the company operating the mill. Tests of the effluent liquor show that it contains 92.7 parts per million of chlorine and 338 parts per million of alkalinity, stated in terms of calcium carbonate.

An interesting feature in connection with the establishment of the Ticonderoga sedimentation bed upon the low ground east of the village has been noted in connection with the occurrence of malarial diseases in the vicinity. Previous to the installation of the works such diseases were extremely common and caused no little amount of inconvenience, suffering, and expense. Since its installation, according to the testimony of physicians practicing in Ticonderoga, there have been practically no malarial cases demanding attention. This effect is probably due to the covering up of the stagnant ponds in this locality, thereby destroying the breeding places of the particular genus of mosquito which transmits the organism causing this disease. While there has been no little stagnant water collected about the bed, the presence of large amounts of lime has been effectual in either destroying the mosquito larvæ or preventing the hatching of the eggs.

EFFECT OF MILL WASTES.

EFFECT ON TICONDEROGA CREHK.

The Ticonderoga pulp mill is situated at the foot of the lowest fall on Ticonderoga Creek, below which the stream is quite flat. At lowwater periods there is practically no current. Sewage matter, sawdust, and fine pulp have been deposited upon the bed of the stream in such quantities that, with the exception of a few inches just below the surface, the channel contains a thick, heavy mass of suspended matter extending for a considerable distance downstream toward the lake. Lower down the water continues shallow and the bottom is covered to a depth of at least 1 foot with a fine, highly organic silt. A small steam tug which draws freight boats up and down the stream forces its way through this mud, the propeller throwing up the material and revealing in no uncertain manner its unspeakable condition. Bacteriologists would expect to find there an advanced state of putrefaction, extremely foul odors, and millions of bacteria per cubic centimeter. In point of fact there appears to be little putrefaction, and no odor except that characteristic of the inorganic waste from the pulp mill. The number of bacteria is 102,000 per cubic centimeter, far less than IRR $121-05-7$ 
might be expected under such conditions, while Bacillus coli communis: so abundant in the river above the mill, is absent below.

This can be the result of nothing else than the disinfecting properties of the pulp-mill waste. The report of E. B. Phelps, set forth in subsequent pages, shows unmistakably that such waste is an excellent germicide. Therefore, while it may be detrimental to a stream not otherwise polluted, like Bouquet River, the waste certainly has beneficial effects upon a stream highly polluted with organic wastes, like Ticonderoga Creek.

The analysis of water from Ticonderoga Creek below the outlet of the sedimentation bed adjoining the pulp mill gives the following results:

TaBlE XXVI.-Analysis of water from Ticonderoga Creek below sedimentation bed of Ticonderoga Pulp and Paper Company.

[Parts per million.]

\begin{tabular}{|c|c|c|c|}
\hline \multicolumn{2}{|l|}{ Mineral. } & \multicolumn{2}{|l|}{ Sanitary. } \\
\hline $\mathrm{SiO}_{2} \ldots \ldots$ & 8.80 & Total solids............. & 67.000 \\
\hline $\mathrm{Fe}_{2} \mathrm{O}_{3}+\mathrm{Al}_{2} \mathrm{O}_{3} \ldots \ldots \ldots \ldots$ & 4.80 & Albuminoid ammonia .. & .090 \\
\hline $\mathrm{CaO} \ldots \ldots \ldots \ldots \ldots \ldots \ldots \ldots$ & 15.53 & Free ammonia ............. & .020 \\
\hline MgO......... & 6.64 & Nitrites............. & .000 \\
\hline $\mathrm{Na}_{2} \mathrm{O} \ldots \ldots$. & 4.72 & Nitrates ............. & .040 \\
\hline Cl ... & 2.90 & Chlorine .... & 2.800 \\
\hline $\mathrm{SO}_{3}^{\prime} \ldots \ldots \ldots$ & 6.90 & Hardness..... & 42.900 \\
\hline $\mathrm{CO}_{2} \ldots \ldots \ldots \ldots$ & 17.19 & Alkalinity ................ & 32.000 \\
\hline $\mathrm{O}$ replaced by $\mathrm{Cl}$. & $\begin{array}{r}67.46 \\
1.31\end{array}$ & $\begin{array}{l}\text { Bacteria per cubic centimeter } \\
\text { B. coli communis . . . . . . . . . . }\end{array}$ & $\begin{array}{l}102,000 \\
\text { Absent. }\end{array}$ \\
\hline Total solids. & 66.15 & & \\
\hline
\end{tabular}

Comparison of creek waters above and below mill.-The important points of information afforded by Tables XXV and XXVI are:

(1) The amounts of lime and soda. It will be noted that the proportion of these constituents in the water taken from the stream below the sedimentation bed is but slightly greater than that above the mill. It might be expected that, inasmuch as there is a considerable amount of soda turned into the stream at the tailrace, as described on page 96 , and large quantities of lime are deposited upon this sedimentation bed, which drains directly into the stream just above this sampling point, there would be a corresponding increase in these compounds in the water. The absence of such increase is very remarkable and seems to throw doubt upon the data submitted in Table XXVI. These 
results are, however, confirmed by the hardness and alkalinity determinations in the sanitary analysis. The former is only 9.1 parts per million greater below the mill than above it, and it will be noted that a large part of this excess may be accounted for by the increase shown in the amounts of magnesia and sulphates. The alkalinity, on the other hand, is greater by only 2 parts per million below the mill than above. This supports the lime and soda determinations and strengthens the supposition concerning the cause of the disproportionate increase in hardness, for, as is well known, the sulphates of the alkaline earths are included in the hardness determination, but not in that of alkalinity. That the increase in the amount of soda is so slight is due to a variety of causes, the most important of which is dilution by Lake George water.

(2) The proportionately large increase in the amount of chlorine, which is plainly not due to additional sewage contamination, but to the spent bleach turned into the sedimentation bed. This bleach, as shown in the discussion of the Willsboro mill, still contains considerable amounts of chlorine.

(3) The high free ammonia, with no nitrites and low nitrates, pointing in a general way to arrested oxidization of organic matter.

(4) The number of bacteria per cubic centimeter, already referred to on pages $97-98$, and the absence of $B$. coli communis.

Comparison of creek and lake waters. - It will be of advantage now to compare the mineral analyses of the water taken from Ticonderoga Creek below the sedimentation bed with that of the lake above the influence of Ticonderoga Creek pollution. It is plain that the results of Ticonderoga Creek pulp-mill pollution will be most prominent and their effects most acute in the stream just below the point at which they are discharged from the mill. The difference between the water at this point and that of the normal lake represents the greatest measure of influence which such waste could possibly have upon the lake. It has already been demonstrated that the mill waste consists almost entirely of lime, soda, and chlorine. Therefore the excess in the amount of these ingredients in the water of the stream over the amount of the same in the lake may be accepted as an indication of the possibility of identifying the waste after it has mingled with the latter. 
The analyses are set forth in a form convenient for comparison below:

TABLE XXVII.-Comparative analyses of water from Ticonderoga Creek below sedimentation bed and from Lake Champlain above influence of creek water.

\begin{tabular}{|c|c|c|c|c|c|}
\hline & Creek. & Lake. & & Creek. & Lake. \\
\hline $\mathrm{SiO}_{2} \ldots \ldots \ldots$ & 8.80 & 11.20 & $\mathrm{Cl} \ldots \ldots . . . .$. & 2.90 & 1. 70 \\
\hline $\mathrm{Fe}_{2} \mathrm{O}_{3}+\mathrm{Al}_{2} \mathrm{O}_{3} \ldots \ldots \ldots$ & 4.80 & 4.20 & $\mathrm{SO}_{3} \ldots \ldots \ldots$ & 6. 90 & 24.40 \\
\hline $\mathrm{CaO} \ldots \ldots$ & 15.53 & 28.83 & $\mathrm{CO}_{2} \ldots \ldots \ldots$ & 17.19 & 22.08 \\
\hline MgO.............. & 6.64 & 9.78 & Alkalinity .......... & 32.00 & 65.00 \\
\hline $\mathrm{Na}_{2} \mathrm{O}_{3} \ldots \ldots \ldots \ldots$ & 4. 72 & 4.58 & & & \\
\hline
\end{tabular}

The amount of lime in the normal water of the lake is shown to be nearly twice as high as that in the most polluted portion of the creek. Therefore this ingredient must be left out of consideration. It may be safely stated that, whatever effect the Ticonderoga pulp-mill waste may have upon Lake Champlain, it does not contribute as much lime as the lake already contains.

Although the amount of sodium in the creek water is slightly greater than that in the lake, the difference is so small that, with the small volume of creek water merged with the large volume of the lake, the identity of the former, so far as the amount of sodium is concerned, would be completely lost. Indeed, it is known that the alkalinity of the water at the northern end of the lake varies by an amount greater than would be produced by the above difference in sodium, even if such were added to or taken directly from the lake water. There are, it is true, similar variations in the quantity of sodium found in the creek water, but the change would hardly go in the direction of higher concentration. The creek, at the time of sampling, was exceptionally low and the concentration of soda about as heavy as it is ever likely to become. Therefore the comparison above made is an extreme one. Under ordinary conditions the soda in the creek will be even less than appears in the above analysis. All things considered, there is absolutely no promise in the determination of lime, soda, or alkalinity, so far as it relates to the tracing of pulp-mill waste.

The amount of chlorine in the creek appears much greater than that in the lake. This, then, may serve as a specific test by which the waste may be traced. The amount of chlorine in the creek above the Ticonderoga pulp mill and just below the village was, according to the table, 1.5 parts per million; therefore all the chlorine contributed by the creek to the lake does not originate in the mill waste. The proportionate amount from the mill may be roughly considered to be the 
difference between 2.9 parts and 1.5 parts, or 1.4 parts per million, a smaller amount than was found in the normal lake. Thus it is shown

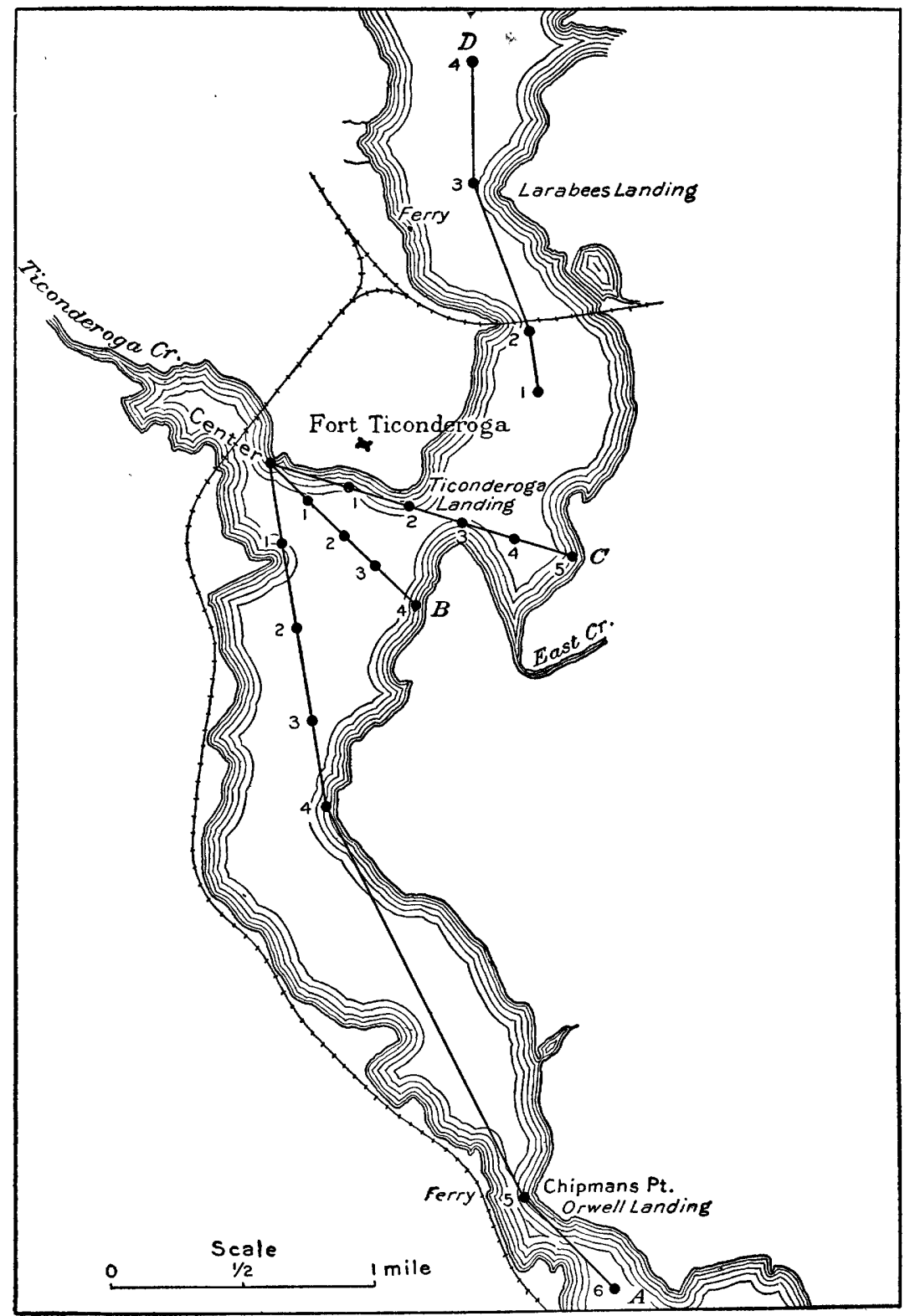

FIG. 8.-Ticonderoga sample series of August 27, 1904.

that the entire amount of chlorine turned into the lake does not originate in the mill. On the other hand, the amount of chlorine in the 
water just above the mill is practically the same as that in the lake, and it follows that if the waste were eliminated from the creek the creek water as it merges into the lake could not be distinguished from the lake water by the chloride test. The difference between the chlorine content of the two waters is therefore due entirely to pulp-mill waste, and any identification of creek water which may arise from this test may be charged unmistakably to the pulp mill. It is highly important to note these facts, in order that no doubt or misconception may arise as to the effect of Ticonderoga sewage and its relation to the chlorine in the water of the lake.

EFFECT OF WASTES ON LAKE CHAMPLAIN.

Sample series of August $2 \%$.-Arrangements were made to collect a series of samples radiating from a center at the mouth of the creek, along three lines, $\mathrm{A}, \mathrm{B}$, and $\mathrm{C}$, and along a fourth line running from a point one-fourth mile south of the Rutland Railway bridge to a point about one-half mile north of Larrabee Landing, along the midchannel of the lake (fig. 8). These samples, as explained in previous investigations, will serve to show the persistence of mill waste in the lake. Line A extends from the mouth of the river in a general southeasterly direction to a point one-half mile beyond Chipmans Point; line $B$ extends from the same center directly across the lake to the opposite shore, while line $\mathrm{C}$, starting at the same point, runs close to the point upon which old Fort Ticonderoga stands, and thence directly across to the opposite shore. The fourth line, which is designated " $\mathrm{D}$," runs as above described.

The wind on the day of sampling, and for some days previous, had been from the south, and at the time of sampling was blowing strong. This would lead to the expectation that the greater amount of evidence concerning the persistence of the mill waste would appear in the lake to the north of the creek. The results are shown in Table XXVIII. 
TABLE XXVIII.-Ticonderoga sample series of August $27,1904$.

[Parts per million.]

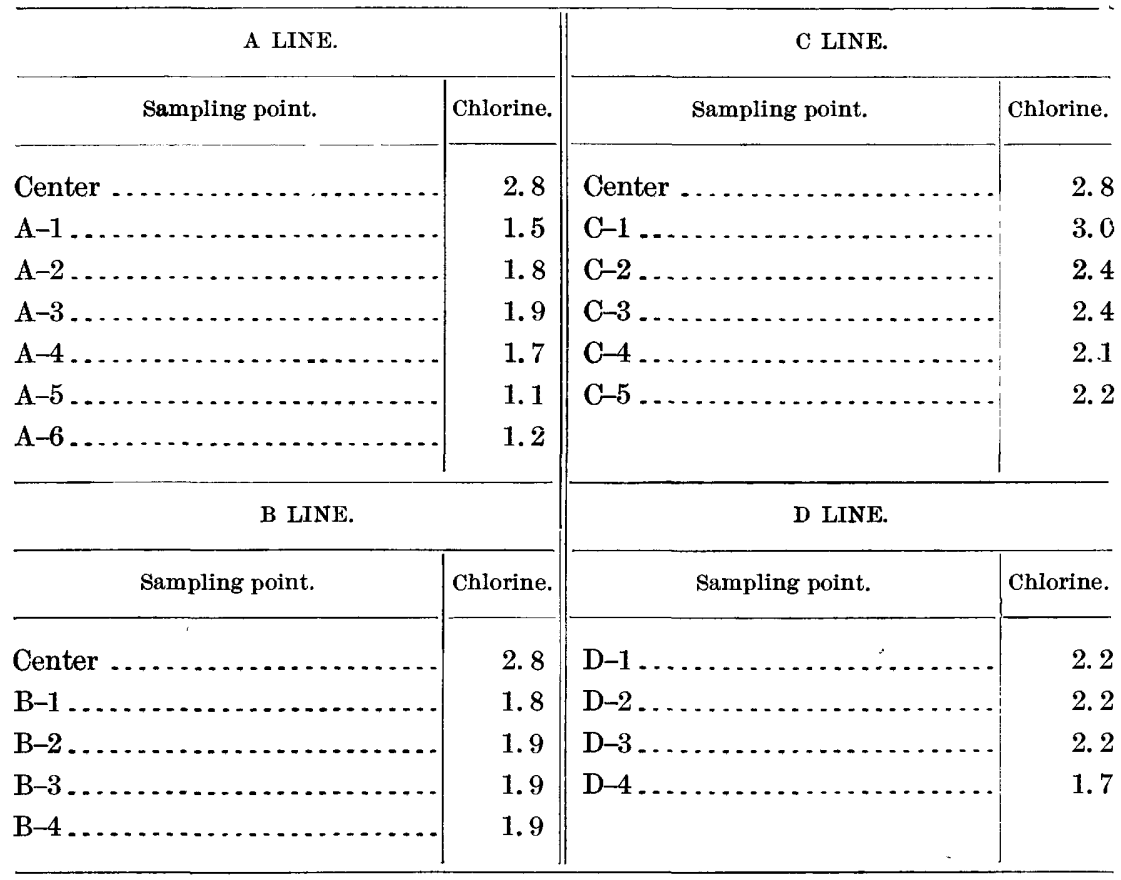

The samples taken along line A show the persistence of the waste in that portion of the lake south of the creek. In view of the fact that the lake flows north, and that the wind, previous to sampling, was from the south, the appearance of abnormal chlorine in the direction opposite to that of the wind and the natural flow gives exceptionally strong evidence concerning the effect of the mill waste upon the lake. That this abnormal chlorine has no other origin is shown by the fact that the samples taken at points 5 and 6 (fig. 8), $3 \frac{1}{2}$ miles to the south of the creek, contained the normal amount. No sources of pollution appear between points 4 and 5 to account for the increase. Line B gives evidence similar to line $A$, while along line $C$ the effects of the wind in blowing the waste northward from the mouth of the creek are clearly shown. The evidence given by the determinations along line $\mathrm{D}$ is corroborative.

The wastes from the mill of the Ticonderoga Pulp and Paper Company, situated on Ticonderoga Creek, persisted in Lake Champlain on August 27, 1904, a distance of at least $1 \frac{1}{4}$ miles south of Ticonderoga Creek against wind and current, and were plainly apparent nearly 3 miles down the lake. How much farther in the latter direction the evidence might have been procured is not known. The distance traversed is sufficient for all purposes. 
Sample series of September 9.-Another series.of samples was taken on September 9, 1904, in order to verify or disprove the existence of the general conditions shown in the series of August 27. The conditions under which the later work was done were similar in all essential respects to those of the earlier work, except that the wind was blowing a gale from the north. The surface current was then opposed to that known to exist at depths below the influence of the wind. An opportunity was thereby afforded to contrast the course taken by the mill waste under conditions extremely different from those in the first series.

Before considering the series of samples, it will be advisable to contrast the characteristics of the water in the creek and in the lake above the influence of creek pollution. The alkalinity and chlorine contents in the water of the creek above and below the pulp mill and in the lake at point 9 , line $A$ (fig. 9), are shown in the following table:

Alkalinity and chlorine in Ticonderoga Creek and Lake Champlain.

[Parts per million.]

\begin{tabular}{|c|c|c|}
\hline & Chlorine. & $\begin{array}{l}\text { Alka- } \\
\text { linity. }\end{array}$ \\
\hline Ticonderoga Creek above pulp mill $\ldots . \ldots \ldots \ldots \ldots \ldots$ & 1.2 & 27 \\
\hline Ticonderoga Creek below sedimentation bed $\ldots \ldots \ldots \ldots \ldots \ldots$ & 6.0 & 31.5 \\
\hline Lake at point 9, line $A, \ldots \ldots \ldots \ldots$ & .9 & 77 \\
\hline
\end{tabular}

It will be noted, by comparing the above results with those obtained at similar points in the series of August 27, that the water from the creek above the pulp mill and that in the normal lake do not differ essentially in respect to chlorine and alkalinity, but the amount of chlorine is considerably larger in samples taken below the sedimentation bed on September 9 than on August 27. This may be explained entirely by the varing conditions in the mill and in the sedimentation bed. In the treatment of bleaching powders in the mill it is the intention, as explained on previous pages, to remove from that powder all the available chlorine. In practice, however, this is not done, and there always remains a small amount of chlorine in the lime sludge which is turned into the sedimentation bed. This amount varies within limits greater than those indicated by the determination of chlorine in the water taken from the creek below the sedimentation bed in the two series. The condition of the sedimentation bed, too, might suffice to explain this difference. It is impossible, in the intelligent management of a sedimentation bed of the character of that installed at Ticonderoga, to turn the waste always in the same direction upon the bed. On one day the liquid waste may, by reason of inequalities in the surface of the bed, 
take a long detour around the bed or be largely held back by deposits of sludge; on another day the course of the waste from the head of the sedimentation bed to the outlet at the foot may be more direct, and

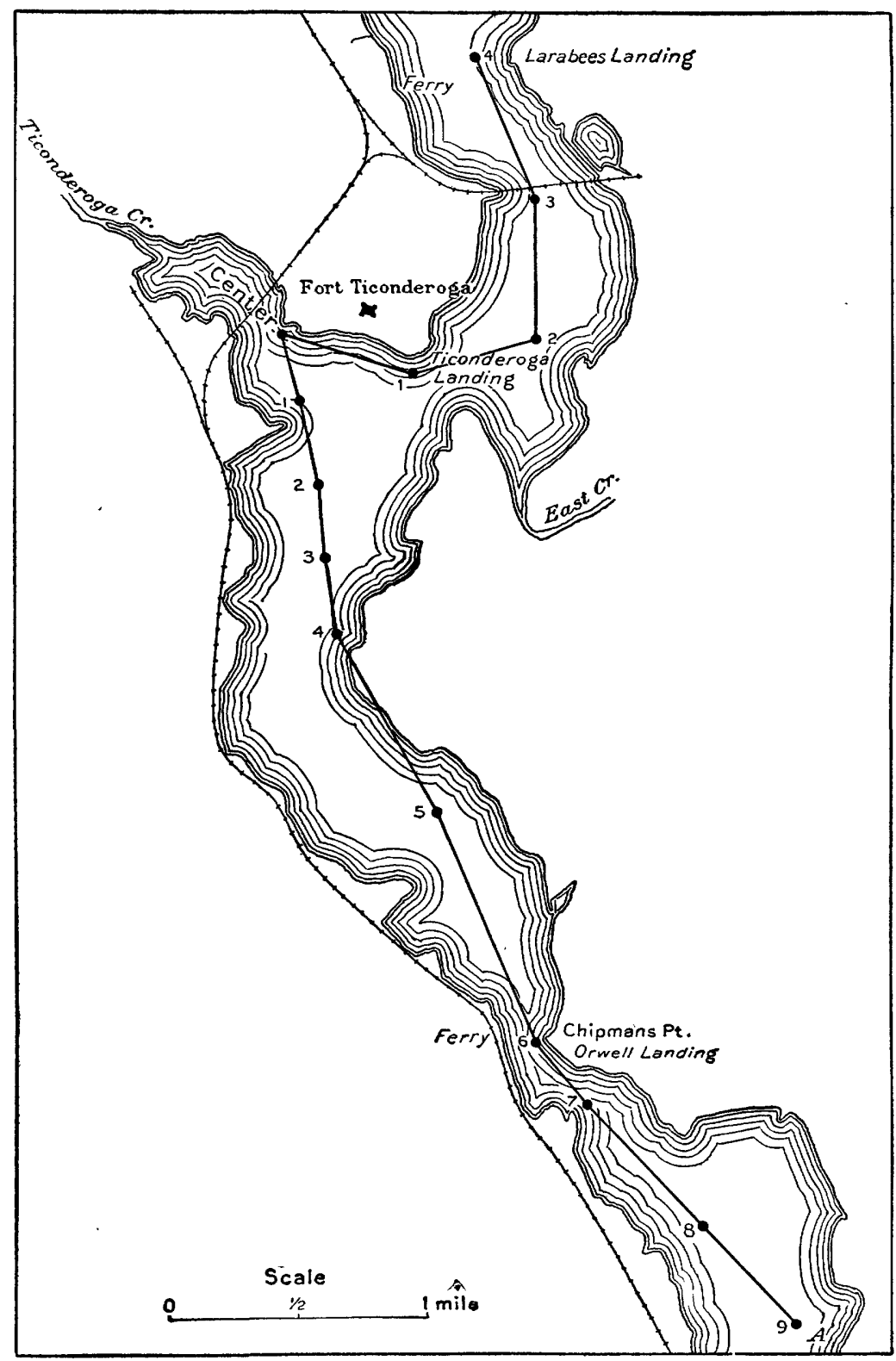

FIG. 9.-Ticonderoga sample series of September 9, 1904.

large amounts of liquor may be emptied into the stream within a short period. These facts are easily demonstrated by observing the surface of the bed and the direction of the currents over it. 
This great excess in the amount of chlorine in the water of Ticonderoga Creek below the sedimentation bed, over that observed in the previous series, does not vitiate any of the conclusions drawn from the results of the determinations in that series. As long as the comparative values in each series are kept in mind and allowed for, the variation in either of the constituents from series to series does not affect the interpretations. The problem in hand is one of comparative values rather than absolute ones, and such comparisons can be made equally as well under diverse conditions, so long as these conditions are determined.

It will be seen in this series that the difference between the amount of chlorine in creek water above the pulp mill and that in the lake at point 9 , line $\mathbf{A}$, is only a small amount, and if the waste were excluded from the creek the water of the creek, when merged into that of the lake, could not be identified by the chlorine determination. This assumption is identical with that stated in the first series. The fact that a large amount of chlorine was found in the creek water below the sedimentation bed renders the problem of identification in the lake simpler than in the first series. It is apparent that almost all the excess of chlorine in the creek water as it discharges into the lake is due to the pulp mill, and the determination of this chlorine at the various points along the sample lines is specific. In considering the sample series of September 9, it should be borne in mind that, as the wind was blowing from the north, the effects of the waste to the south of the creek should be more apparent than in the series of August 27. The following table gives the results of the chlorine determinations along lines $\mathrm{A}$ and $\mathrm{B}$, shown in fig. 9 .

Table XXIX.-Ticonderoga sample series of September 9, 1904.

A LINE.

\begin{tabular}{|c|c|c|c|}
\hline Sampling point. & Chlorine. & Sampling point. & Chlorine. \\
\hline Center ... & 8.8 & A-5... & 1.8 \\
\hline$A-1 \ldots \ldots$ & 3.1 & $A-6 \ldots \ldots \ldots$ & 1.4 \\
\hline$A-2 \ldots .$. & 2.9 & $A-7 \ldots$ & 1.0 \\
\hline$A-3 \ldots \ldots \ldots \ldots \ldots$ & 2.9 & A-8 $\ldots$ & 1.1 \\
\hline$A-4 \ldots \ldots \ldots$ & 7.6 & $A-9 \ldots \ldots \ldots$ & .9 \\
\hline
\end{tabular}

B LINE.

\begin{tabular}{|c|c|c|c|}
\hline Center $\ldots \ldots \ldots \ldots \ldots \ldots$ & 8.8 & B-3 $\ldots . . . . . . . .$. & 2.5 \\
\hline B-1 $1 \ldots \ldots \ldots \ldots$ & 2.9 & $B-4 \ldots \ldots$. & 2.9 \\
\hline$B-2, \ldots$ & 2.6 & & \\
\hline
\end{tabular}


It will be noted, on examination of the data given, that the evidences of Ticonderoga Creek pollution are apparent as far south as sampling point 6, opposite Chipmans Point. The distance from the creek mouth to Chipmans Point is about 3 miles. This is probably as far as the evidence of pulp-mill pollution existed on the day of sampling, for at point 7 , about one-fourth mile south of Chipmans Point, the amount of chlorine is normal. Considering line B, it will be noted that marked evidences of pollution extend as far as the samples were collected. This in spite of the fact that for a considerable period a heavy wind from the north had been blowing so strongly that it made a farther extension of the line of samples hazardous to the collectors. The persistence of this chlorine down the lake does not necessarily show that the water of the creek had proceeded against the wind up to point 4 , but that the lake in that region and for a considerable distance to the north contains a high amount of chlorine due to the constant pouring out of waste from Ticonderoga Creek, and that the condition along the entire lake to the north has become general.

The sample series of September 9 corroborates that of August 27, and gives assurance that the waste from the Ticonderoga pulp and paper mill exerts a considerable influence up and down the lake from the mouth of Ticonderoga Creek. That this should be the case is not surprising. As has already been stated, the lake in this region is narrow and shallow, and its power to conceal foreign matter is far less than that of the broad lake opposite the mouth of Bouquet River. It may be safely stated, then, that the effect upon the lake of Ticonderoga Creek, with its burden of pollution, is unmistakable.

CONCLUSTONS.

The determination of whether the waste from the Ticonderoga pulp mill may be identified in the lake is but a part of the problem concerning which the investigation was made. Having shown that the wastes do persist in the lake, it becomes necessary to consider whether or not such wastes have a deleterious effect. It has been maintained on previous pages that the waste from a soda-pulp mill is entirely inorganic, and the experiments which were made in connection with waste from the Willsboro mill fully substantiate this claim. It has also been shown that the waste from the Ticonderoga mill is practically the same as that from the Willsboro mill. Therefore the decision concerning the possible deleterious effect of this waste on the lake must be based upon the influence which lime, soda, and chlorine would have on the water.

The analytical statements on previous pages have demonstrated that the amount of lime and soda in the creek at the point at which it is most concentrated is less than that which normally occurs in the lake. 
This was clearly shown by the actual determinations of lime and soda and by repeated determinations of alkalinity. Therefore it is a safe assumption that the amount of these substances discharged from the sedimentation bed and from the mill does not in any way affect the lake water. Hence the only possible deleterious effect which the mill wastes could have upon the lake results from the increased amount of chlorine which has been shown to be imparted to the water.

Chlorine occurs in water usually in the form of common salt. This is almost invariably true in the waters of the northeastern part of the country, and there is no doubt that the chlorine derived from the Ticonderoga pulp mill is instantly converted into sodium chloride as soon as it mingles with the water. Now, what deleterious effect can be produced by this amount of sodium chloride? In the most concentrated condition in which it has been discovered the amount may still be called extremely low. The majority of healthful water supplies in the United States contain far greater proportions of salt. It is true that the amount of salt in a water above the normal for the region is usually eonsidered by sanitarians as an indication of sewage pollution, but in the present case it has been shown that the amount of salt derived from sewage pollution in Ticonderoga Creek is not greater than that which occurs in the lake. In other words, it is certain that the source of the excess chlorine is the pulp mill. As such it can in no wise be harmful. The increase in chlorine indicated is by no means sufficient to make its presence known to the taste, nor can it in any way affect deleteriously any substance already within the water. Sodium chloride is a most stable salt, and years of research have shown that, except under peculiar circumstances which never take place in this part of the country, it remains in its original condition though almost every other ingredient of the water be changed. The inevitable conclusion must therefore be that the waste from the Ticonderoga pulp mill is in no wise detrimental to Lake Champlain.

\section{GENERAL CONDITIONS IN IAKE CHAMPLAIN.}

ALG五.

The statement has repeatedly been made that, as a result of the discharge of foreign material into Lake Champlain, there is a superabundance of algæ of the offensive species. In fact, this has been considered one of the main points of evidence in support of the charge that the lake is being damaged by municipal and industrial wastes. Therefore it was believed necessary to give as much attention as possible to this phase of the question. It was impossible to undertake the refined series of experiments necessary for a final opinion on this point, but sufficient observations were made to permit certain generalizations. 
Nearly all quiescent surface waters contain microscopic organisms in large numbers. The occurrence of these organisms in such waters is as natural as the occurrence of fish. They take their place in the flora and fauna of water life as inevitably as do the water lily, the tadpole, the eel, or the brook trout. The mere presence of algæ in a water is certainly not evidence of any unnatural feature. On the contrary, their absence would be unique. Therefore the supposition that because of a superabundant growth of algæ along the shores of a lake there must be polluting material turned into the water is unfounded.

There are many varieties of algæ. A sample of water from almost any lake will reveal numerous kinds. Nevertheless, they have a seasonal distribution. For example, a certain'species may be found in abundance in spring and in only small numbers in summer or autumn; likewise, a different species may be scarce or absent in spring but especially numerous in summer or fall. Similarly, a certain kind of alga may be abundant during one year, but scarce during the next year or a cycle of years thereafter. These variations may be due to causes quite as natural as those which bring about similar fluctuations in the potato, corn, wheat, or cotton crops. The fact that a certain troublesome alga appears along the shores of a lake during several seasons in greater abundance than in former years can by no means be attributed offhand to any change artificially made in the character of the water.

Some organisms thrive under certain conditions of water; therefore the presence of such organisms in exceptional numbers may be taken as an indication of those conditions. On the other hand, the absence of these forms may in many cases be interpreted as an evidence of the nonexistence of those conditions.

Algæ die out unless food material is present, and increase in number as the food is increased. Organic matter, by its oxidization, supplies carbon dioxide and nitrates, which are favorite food for algæ. Therefore, other things being equal, anything which would increase or decrease these products would have a consequential effect upon the number of algæ.

Algæ impart certain appearances, odors, and tastes to the water. Some of these features are the result of life processes of the organisms, while others are due to the products of their death and decay. These odors and tastes have no relation to any polluting material that might be placed in the water, but occur everywhere that the organisms flourish, whether it be in the high mountain lake with no suspicion of artificial contamination, or in a stagnant pond which receives city sewage. 
The condition of Lake Champlain during the summer of 1904 was not such as to lead the observer to believe that it was abnormally infested with water organisms. It is true that they were abundant, especially during the latter part of Augast, but no more than the natural conditions would warrant. To the rocks along the sheltered shores there was attached a thick carpet of Spirogyra, which gave to the water an offensive taste and, as the lake receded, was left to rot and dry in the sun. Whether or not this alga was made more abundant by the organic wastes from Ausable River and Burlington than it would have been if these sources of pollution were absent is not known. Certainly the alga did not occur in greater profusion than in other lakes which are known to be pure. During the earlier part of the summer the alga Ulothrix was found upon the rocks in considerable quantity. As Spirogyra and Ulothrix appeared to be the organisms which give cause for complaint, it was determined to make as comprehensive tests of the effect of the soda and sulphite wastes upon them as time and facilities would allow. The tests reported have not the finality of a detailed investigation, but they serve to show certain general facts.

EFFECT OF MILL WASTE ON ALGE.

\section{EXPERIMENT 1.}

The alga known as Ulothrix was collected from the shores on the west side of the lake and placed, with the stones to which it was attached, in pails filled with lake water. This was done on August 3, 1904, and the plants were allowed to grow until August 10, at which time they were in a healthy condition, in no case being killed or stunted by reason of their transference from the lake to the pails. The water in which the plants were growing was then treated with effluent from the sedimentation bed of the Willsboro mill, as follows: One pail left untreated for control; second pail mixed in the proportion of 1 part of waste to 25 parts of water; third pail, 1 part of waste to 100 of water; fourth pail, 1 part of waste to 1,000 of water; fifth pail, 1 part waste to 5,000 of water.

On August 16, six days after this treatment, the growth in the untreated specimen continued normal; that in the 1 to 5,000 solution appeared somewhat bleached; the 1 to 1,000 specimen was markedly damaged, while the stones in all the other pails were clean.

\section{EXPERIMENT 2.}

An experiment similar to the one above outlined was commenced upon Spirogyra on October 18. The plant is extremely rugged in character, and that selected for experiment was in excellent condition. Dilutions of waste were made the same as in the previous experiment. 
At the end of two days the alga in the pail containing the solution in the proportion of 1 to 25 were dead, while at the end of two weeks all the others had been killed except the specimen in the dilution of 1 to 5,000 , which had been markedly bleached and was in an unhealthy condition. Those in the untreated pail were vigorous.

\section{BACTERIA.}

\section{EFFECT OF MILL WASTES.}

SAMPLES FOR TESTING.

In order to test the effect of this waste on bacteria in general and on the specific germs of disease, three samples were sent to Mr. C-E. A. Winslow, of the bacteriological department of the Massachusetts Institute of Technology, and by him were turned over to Mr. Earle B. Phelps for investigation. The report of Mr. Phelps, dated October 11, 1904. follows:

REPORT OF MR. EARL B. PHELPS.

Sir: Last August you sent to Mr. C-E. A. Winslow three small bottles of liquid marked "Effluent from sedimentation bed, soda process pulp mill," with a request that they be examined as to their germicidal properties, in order to determine the probable effect of the discharge of such a liquor into a stream. This work was turned over to me by Mr. Winslow, and I have the following report to make upon the results of my investigation upon this waste liquor. At Mr. Winslow's suggestion the following tests were made:

(1) Physical examination, determination of alkalinity, and of numbers of organisms in the samples as received.

(2) Effect of liquor on mosquitoes (Culex), larvæ and pupæ.

(3) Effect of liquor on the bacteria in sewage; (a) Germicidal action on the organisms of sewage which grow upon gelatine; (b) Effect on the putrefaction of sewage as measured by the "incubator test."

(4) Effect of liquor on specific disease germs; (a) B. typhosus; (b) B. anthracis (spores).

The samples as received by us differed among themselves, and we are informed by you that this is the normal variation to be expected in the liquor. I therefore carried out all the tests upon either two of the samples or upon all three of them.

Determinations.-The first sample, which I have called A, was a clear, almost colorless liquid, possessing a very faint empyreumatic odor. Plated out on algæ and allowed to develop at $37^{\circ} \mathrm{C}$. for forty-eight hours, it was found to contain 10 bacteria per centimeter. It was alkaline in reaction to the amount of 3.4 per cent normal.

The second sample, B, was decidedly turbid and of a pale-yellow color; no odor. It contained 2,100 bacteria per centimeter and its alkalinity was equal to 2.8 per cent normal.

The third sample, $\mathrm{C}$, was colorless and odorless and was found to contain 13 bacteria per centimeter and to have an alkalinity of 3.6 per cent normal.

Effect on mosquitoes.-In a mixture of equal parts of tap water and liquor, some larvæ and pupæ lived for eight hours, although the majority died during that period. The liquor was observed to form a heavy flocculent precipitate when mixed with the water, and no doubt carried down with it any food material which might have been present; the larvæ were seen grubbing upon this heavy precipitate in an endeavor to feed. It is very possible that they may have been simply starved out rather than 
killed by any poisonous effect of the liquor. Several full-grown pupæ were placed in the undiluted liquor, in which they lived for about thirty hours. I had previously found that both larvæ and pupæ of Culex thrive in a fairly strong solution of uranic acetate if food be presented.

Germicidal effect on sewage bacteria.-I plated out a sample of Boston sewage and then mixed some of the sewage with varying proportions of the liquor. The tubes thus prepared, together with a control tube of sewage alone, were set aside for six hours; then they were plated out and the number of bacteria determined. This experiment was made with both $A$ and $B$. It was necessary to take into account also the original number of bacteria present in the liquor, these being greatly different in the two samples. The results of this test are given in Table XXX.

TABLE XXX.-Germicidal action of the soda-mill waste liquor upon the organism of sewage.

\begin{tabular}{|c|c|c|c|c|c|c|}
\hline \multirow{2}{*}{$\begin{array}{l}\text { Per cent of liquor } \\
\text { by volume in } \\
\text { mixture. }\end{array}$} & \multicolumn{4}{|c|}{ Number of bacteria. } & \multirow{2}{*}{\multicolumn{2}{|c|}{$\begin{array}{l}\text { Per cent of reduc- } \\
\text { tion. }\end{array}$}} \\
\hline & \multicolumn{2}{|c|}{ Initial number. } & \multicolumn{2}{|c|}{$\begin{array}{l}\text { Final number after } 6 \\
\text { hours. }\end{array}$} & & \\
\hline \multirow[t]{2}{*}{ Control (0)........ } & \multicolumn{2}{|c|}{270,000} & \multicolumn{2}{|c|}{290,000} & \multicolumn{2}{|c|}{$3 a$} \\
\hline & A. & B. & A. & B. & A. & B. \\
\hline $\begin{array}{l}50 \ldots \ldots \\
80 \ldots \ldots\end{array}$ & $\begin{array}{r}135,000 \\
45,000\end{array}$ & $\begin{array}{r}136,000 \\
48,000\end{array}$ & $\begin{array}{r}1,400 \\
600\end{array}$ & $\begin{array}{l}2,400 \\
1,200\end{array}$ & $\begin{array}{l}99.0 \\
98.7\end{array}$ & $\begin{array}{l}98.2 \\
97.5\end{array}$ \\
\hline
\end{tabular}

$a$ Increase.

NoTE.-The initial number under $A$ and $B$ is calculated from the number in the sewage itself and in the two samples of liquor, as already given.

The results here found are somewhat peculiar in that with a greater addition of liquor the percentage reduction in numbers is less. This may be explained, perhaps, by the presence of organisms in the liquor itself. These organisms doubtless can withstand the action of the liquor and multiply rapidly when that liquor is mixed with sewage. The reduction in numbers is seen to be great in any case.

The "incubator test," so called, is used to determine whether or not putrefaction will take place within the sewage or effluent under certain laboratory conditions. A determination of the "oxygen consumed" is first made on the sample. A small glass-stoppered bottle is then filled completely with the sewage, stoppered up, and placed in an incubator kept at a certain definite temperature. I used, for convenience, $37^{\circ}$ for five days. The oxygen consumed is again determined. If nitrifactive decomposition has taken place the organic matter is thereby rendered less stable and is more readily oxidized. Hence an increase in the oxygen consumed during the incubation is an indication of putrefaction having taken place. This test was applied to a series of samples containing varying amounts of the paper-mill liquor, together with a control containing no such liquor, and the results are given in Table XXXI. 
TABLE XXXI.-Effect of soda-mill waste liquor upon the putrefaction of sewage as shown by the "incubator test."

[Parts per million.]

\begin{tabular}{|c|c|c|c|c|c|c|}
\hline $\begin{array}{l}\text { Per cent of liquor } \\
\text { in mixture. }\end{array}$ & \multicolumn{6}{|c|}{ Oxygen consumed. } \\
\hline \multirow[t]{2}{*}{ Control ............ } & \multicolumn{2}{|c|}{ A. } & \multicolumn{2}{|c|}{ B. } & \multicolumn{2}{|c|}{ c. } \\
\hline & Initial. & Final. & Initial. & Final. & Initial. & Final. \\
\hline $\begin{array}{r}0 \\
10 \\
1\end{array} \ldots \ldots$ & $\begin{array}{l}33 \\
38 \\
33\end{array}$ & $\begin{array}{l}50 \\
39 \\
57\end{array}$ & $\begin{array}{l}33 \\
40 \\
33\end{array}$ & $\begin{array}{l}50 \\
41 \\
52\end{array}$ & $\begin{array}{l}33 \\
34 \\
33\end{array}$ & $\begin{array}{l}50 \\
36 \\
55\end{array}$ \\
\hline
\end{tabular}

It appears from these figures that the liquor almost entirely prevents the putrefying activity of the organisms when 10 per cent is present, but that if present in only. small amounts it slightly increases the putrefaction. This result may be due to its alkaline reaction, by which it neutralizes the acid products formed and allows the organisms to work with less interference from their own by-products.

Effect on specific disease germs. - I have also tested the germicidal power of this waste liquor upon certain specific disease germs, namely, Bacillus typhosus and spores of Bacillus anthracis.

(a) Bacillus typhosus.

A four-day broth culture of this organism was diluted and treated with varying amounts of the liquor. At the end of six hours these cultures were plated out on agar with proper dilution and grown fifteen hours at $37^{\circ} \mathrm{C}$. The results are given in Table XXXII:

TABLE XXXII.-Germicidal action of the soda-pulp-mill waste liquor upon Bacillus typhosus.

\begin{tabular}{|c|c|c|c|}
\hline $\begin{array}{c}\text { Per cent of liquor in } \\
\text { mixture. }\end{array}$ & Initial number. & \multicolumn{2}{|c|}{ Final number. } \\
\hline Control (0).... & $34,000,000$ & \multicolumn{2}{|c|}{$120,000,000$} \\
& & "A." & "B." \\
\hline 50 & $17,000,000$ & 0 & 0 \\
10 & $31,000,000$ & 0 & 0 \\
1 & $34,000,000$ & 1,300 & 0 \\
\hline
\end{tabular}

The liquor is seen to have a very strong germicidal action upon Bacillus typhosus even in quite dilute solution.

(b) Bacillus anthracis (spores).

IRR 121-05-8 
A 24-hour broth culture of this organism was heated to $80^{\circ} \mathrm{C}$. for fifteen minutes to kill vegetative cells. This culture was then treated exactly as was the typhosus culture, with the results given in Table XXXIII:

TABLE XXXIII.-Germicidal action of the soda-pulp-mill waste liquor upon Bacillus anthracis (spores).

\begin{tabular}{|c|c|c|c|}
\hline $\begin{array}{l}\text { Per cent of liquor in } \\
\text { mixture. }\end{array}$ & Initial number. & \multicolumn{2}{|c|}{ Final number. } \\
\hline Control $(0) \ldots$ & 9,600 & \multicolumn{2}{|c|}{460,000} \\
\hline . & & "A." & "c." \\
\hline 50 & 4,800 & 0 & 0 \\
\hline 10 & 8,000 & 110,000 & 190,000 \\
\hline 1 & 9,500 & 125,000 & 200,000 \\
\hline
\end{tabular}

These figures show that in a 50 per cent solution the Bacillus anthracis are all killed, but that in the greater dilution there is a considerable growth of this organism.

Conclusions. - To summarize, it appears that for some bacteria the effluents studied have marked germicidal power. Even 1 per cent is fatal to Bacillus typhosus in six hours. This strength of solution, however, rather favors the activity of ordinary putrefactive bacteria. In 10 per cent solution, on the other hand, putrefactive processes are checked, although Bacillus anthracis can still multiply. In 50 per cent effluent liquor anthrax spores are killed and over 98 per cent of common sewage bacteria are destroyed. The same solution is fatal to mosquito larvæ in a few hours and to pupæ in a day or more. Certain bacteria may live in the undiluted effluent, as shown by the fact that none of the plates made from the original sample were quite sterile. With regard to the effect of the discharge of this liquor into a stream, it is evident, of course, that the relative volume of the discharge, as compared with that of the stream, is a prime factor. In a dilution of 100 times there will be little antiseptic action, but a very considerable precipitation of the impurities of the water by the waste liquor, which precipitate will carry down with it and probably destroy a large percentage of the organisms present. I found that a sample of Boston sewage mixed with 1 per cent of the waste liquor was completely clarified. The waste might indeed be used as a precipitant for domestic sewage. In a stream this process would cause a serious accumulation of sludge in the channel if the velocity were not too great. In any case accumulations are bound to occur behind milldams and in the lower reaches of the stream. This accumulated sludge, while antiseptic at first, will doubtless lose much of its germicidal properties by diffusion and will eventually putrefy and cause a nuisance.

The effect of the effluent upon the bacillus of typhoid fever indicates that it might have a favorable effect upon a stream as regards the presence of disease germs.

Respectfully submitted.

Earle B. Phelps.

FISH.

The claim that fishing in Lake Champlain is not so good as in former years is apparently borne out by the facts, but the idea that this condition is caused by polluted material is erroneous. On the lake on a 
still day thousands of perch were seen coming to the surface, and perch and lake bass lie off the piers in abundance. Only rarely, however, can they be induced to take the hook, though the most tempting bait is lowered before their noses. All about the sewer outlet of Burlington and up in Bouquet River even to the outlet of the sedimentation bed numerous shoals of very small fish may be seen at almost any time. Diligent inquiry among the people living along the lake on both sides failed to substantiate the startling assertions so often made in the public press concerning the enormous accumulations of dead fish along the shores. In Ausable River and in Ticonderoga Creek below the pulp mills no evidences of fish life could be found.

\section{SAWDUST AND GROUND WOOD.}

There are large accumulations of sawdust and ground wood along the shores and about the mouth of almost every Adirondack stream. Although this is probably not productive of any poisonous matter, it has its serious effects: First, it is damaging to shore property in that it presents an unsightly appearance, destroys the beaches, and renders the region in which it is deposited generally objectionable; second, it covers the spawning beds and drives fish to other localities; and, third, it is a needless waste of good material. Sawdust, if properly handled, is a marketable product and can in any case be used for fuel.

Sawdust and ground wood when turned into streams is physically objectionable, especially when water supplies are taken out below the point at which such material is deposited. In one case in the Champlain region considerable damage has been done to a filtration system by the deposits accumulated upon the beds. The evil is a growing one and must eventually receive attention.

\section{SUMMARY.}

1. Soda-pulp wasto from the Champlain mills of the New York and Pennsylvania Company, situated at Willsboro, N. Y., is not perceptible in Lake Champlain beyond a maximum distance of 2,000 feet from the mouth of Bouquet River, provided that the sedimentation bed installed at Willsboro is used.

2. Sulphite-pulp waste from the mills of the J. \& J. Rogers Company, situated at Ausable Forks, N. Y., is apparently perceptible in Lake Champlain for a considerable distance from the mouth of Ausable River.

3. The sewage of Burlington and Winooski River is a serious damage to that part of Lake Champlain immediately surrounding. The inhabitants of Burlington are "drinking from their own cesspool." 
4. Soda waste from the mills of the Ticonderoga Pulp and Paper Company, situated at Ticonderoga, N. Y., causes a high proportion of chlorine to appear in the lake water. There is no real damage from this source.

5. The water of the broad lake is of good quality.

6. The sewage conditions as a whole are a growing menace, and if the lake is to be preserved as a water supply the entire question should be studied from interstate and international standpoints and the necessary safeguards provided. 


\section{IN D EX.}

Adirondack Mountains, iron minesin, open-

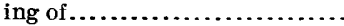

Algæe, conditions of existence of ......... 109 effect of mill wastes on............. 110-111 growth of, complaints of . .......9, 65, 108

Anthrax spores, effect of mill wastes on.... 111,

113-114

Appletree Shoal, sewage emptied near.... 66 water supply from ................. 66

Argentine, Kans., water at, analysis of.... $\quad 38$

Ausable Chasm, location and character of . 48 views in . . . . . . . . . . . . . . . . 24,32

Ausable Forks, N. Y., location and industries of $\ldots \ldots \ldots \ldots \ldots . . . . . . .$.

Ausable Point, width of lake at........... Ausable River, effect of sulphite-pulp wastes on .

falls on, view of

fish in ........................... 115

industries on ................... 48

investigation at mouth of . . . . . . . . . . 54-65 maps showing ............. 54,57,60 origin and course of $\ldots \ldots \ldots \ldots \ldots \ldots \ldots . .48-49$ pollution of . . . . . . . . . . . . . . . . 49-52 valley of, character of............ 15 water of, analysis of............... 52

Bacillus coli communis, occurrence of.... 67 ,

$81,83,86,88$

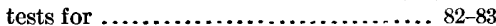

Bacteria, effect of mill wastes on....... 111-114 Balanus miser, occurrence of ............ 14 Bates, E. L., acknowledgments to ........ 10 Bayonne, N. J., water at, analysis of...... 38 Black-ash sludge, origin and character of. . 30-35 Bleach, production of

Bouquet River, comparison of other water supplies and ............... 38-39

effect of soda-mill wastes on ........ 36-39 fish in .......................... 115

fioods on, effect of $\ldots \ldots \ldots \ldots \ldots \ldots \ldots \ldots . \ldots \ldots$

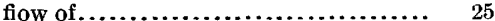

investigations at month of .......... 41-48

maps showing .............. 40,42,46 origin, course, and flow of .......... 21-23 pollution of $\ldots . . \ldots \ldots \ldots \ldots \ldots \ldots \ldots . .22$

trough over, view of ................ 18

valley of, character of............... 15

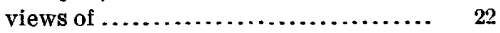
water of, analysis of ............ 36, 37, 38

water power on ................... 22

Bulwagga Bay, location of $\ldots \ldots \ldots \ldots \ldots \ldots 16,18$
Burlington, Vt, fish near

investigation of lake water at, maps showing . . . . . . . . . . $77,79,84,87$

lake front at, views of ............. 66

location of ........................ 66

sewage of ...................... 66-67

complaints of .................. 9

damage to lake from ............ 90 water supply of .................9-10,66

analysis of $\ldots \ldots \ldots \ldots \ldots$

intake of $\ldots \ldots \ldots \ldots \ldots \ldots \ldots \ldots \ldots 6,71-74$

past history of ..................68-74

present condition of ............. 74-90

investigations of ............... 75-88

conclusions concerning ....... 88-90,115

Bush, C. E., acknowledgments to .......... 10

Cedar Rapids, Jowa, water at, analysis of.. $\quad 38$

Cellulose, character of ................. 23-24

Champlain, Lake. See Lake Champlain.

Champlain, Samuel de, discovery of Lake

Champlain by ............... 11

Champlain Canal, opening of ............ 11

Chipmans Point, water at, analysis of .... 91-92

Clinton, Iowa, water at, analysis of....... 38

Clintonville, N. Y., location and character

of....................... 48

Council Bluffs, Iowa, water at, analysis of.. $\quad 38$

Crandall, T. H., on Burlington water supply .................68, 70,72

Crown Point, fortifications on, cost of..... 17

fortifications on, ruins of, view of ..... 18

lake at, character of ............... 16-17

width of $\ldots \ldots \ldots \ldots \ldots \ldots \ldots \ldots \ldots .17$

Cumberland, Md., water at, analysis of... 38

Diarrhea, occurrence of ..........69-71, 74, 89

Dibble Mountain, location and altitude of . 17

Dodge, Kans., water at, analysis of ....... $\quad 38$

Ellis, A. H., acknowledgments to ......... 10

El Paso, Tex., water at, analysis of ....... 39

Emmons, Ebenezer, on Champlain Valley .. 14-16

Essex Island, water near, analysis of ..... 63

Ethan Allen, Fort, sewage of . ........66, 85

Fish, destruction of, complaints of . 9,39,114-115

Floods, effect of, on sedimentation bed ... 35-36

Fossils, occurrence of ................. 14

Four Brothers Island, water near, analyses of ............................ 20

Frederick, Fort, construction of ........ 17

Freight on Lake Champlain, decline of.... 13

Geologic history of Champlain Valley .... . 15-16

Geology of Champlain Valley ............ 15-16 
Gull Island Reef, water at, analysis of .....

Hatch, Edward, jr., acknowledgments to..

Hills, Joseph L., analyses by. on Burlington water supply........... 68,80

Houston, Tex., water at, analysis of ....... 38

Indians, warfare of, along Lake Champlain.

International Pulp Company, water power of, view of.

Investigation, character of . .. 19,24 methods of ...................... 39-41,53

Jones Point, water near, analysis of....... 20

Juniper Island, water near, analysis of..... 20,63

Keeseville, N.Y., location and industries of. view at.

water supply of

Lake Champlain, algæ in .............. 108-111

assimilative power of ............... 74-75

character of $\ldots \ldots \ldots \ldots \ldots \ldots \ldots \ldots \ldots, 16-17$

complaints of pollution of............

depth of $\ldots \ldots \ldots \ldots \ldots \ldots \ldots \ldots \ldots \ldots, 16,18$ description of....................... 14-19

effect of sewage on .................. 89-90

effect of soda-mill waste on .... 39-48,102-108

conclusions concerning ........ 47-48, 107

investigation of $\ldots \ldots \ldots \ldots \ldots \ldots, 41-47,102$ methods of $\ldots \ldots \ldots \ldots \ldots \ldots \ldots .39-41$

effect of sulphite-pulp waste on ........ 53-65 conclusions concerning .......... 62-65 investigations of ................. 53 methods of .................. 53

function of, as water supply.......... 13-14 history and development of.......... 11-14 investigations on, maps showing...... 40, $42,46,54,57,60,77,79,84,87,101,105$

map of $\ldots \ldots \ldots \ldots \ldots \ldots \ldots \ldots \ldots \ldots \ldots, 14$ upper end of, character of ........... 16-17 pollution at ..................... 90-108 water at, character of ............ 90-93 water of, analyses of ............... 41-44 $46,55-56,58-59,62-63,69,73,76,78$ $80,84-86,88,92,94,100,103-104,106$ character of ............... 19-21, 90-93 chlorine in .................... 108 comparison of Ticonderoga Creek water and .................99-100 condition of, summary of ......... 116

width of ............................ 14, 17

Lime, percentage of, in soda-mill wastes .. $\quad 35$

Lime, caustic, use of ................... $\quad 30$

Lime sludge, origin, character, and disposition of $\ldots . . \ldots \ldots \ldots \ldots \ldots \ldots, 30-33$

Liquid effluent, second, analysis of .........

Liquid effluents, origin and character of .. 26-30

Los Angeles, Cal., water at, analysis of ....

McCullough, John G., acknowledgments to

investigation requested by .

Maquoketa, Iowa, water at, analysis of .....

Mason, R. L. P., acknowledgments to .....

Mason City, Iowa, water of, analysis of ....

Massachusetts, lakes in, solids in ..........

Michigan, Lake, water of, analysis of......

Minneapolis, Minn., water at, analysis of..

Moat, C. P., acknowledgments to..........

Modiola, occurrence of.

Moosehead Lake, Me., water of, solids in..

Mount Vernon, Ohio, water at, analysis of.
Page.

Mya arenaria, occurrence of............. 14

truncata, occurrence of............... 14

Natica clausa, occurrence of ............. 14

Newell, F. H., letter of transmittal by ..... 7

New England Water Works Association, paper read before ..............

New York and Pennsylvania Company, mills of, location of $\ldots \ldots \ldots \ldots \ldots 22,33$

mills of, manufacture of soda-pulp at.. 24-36 sedimentation bed of.........33,35,47-48 trough of, view of ................ 18 view of ......................... 24 wastes of, disposal of............. 33-36

effects of..................... $36-40$ effects of, summary of ..... 47-48,115 weir of, view of ................. 32 Nichols, W. R., analyses by ............ 69 Paine, A. G., jr., acknowledgments to ..... 10 Pecten islandicus, occurrence of.......... 14 Phelps, Earle B., on mill wastes and bacteria...................98, 111, 114

Poplar, analysis of .................... 34

use of................................

Ropulation on Lake Champlain, rise and fall of .................... 12

Postville, Iowa, water at, analysis of ..... 38

Prescott, S. C., analysis by .............. 72-73 Providence Island, water near, analysis of. 68 Pueblo, Colo., water at, analysis of ........ 38 Pulp, chemical, character of............. 23 Pulp, wood, accumulations of ......... 38-39, 65 constituents of ..................... 23-24 Pulp mills, advantages and disadvantages

of.................... 9, 39, 47,97

complaints concerning .............. 9

Pulp, soda, manufacture of ............ 24-33

manufacture of, processes of ......... 95-96

wastes of ...................... 25-36

effect on Bouquet River from.. 36-39 effect on LakeChamplain from. 39-48,

$102-108$

effect on Ticonderoga Creek

from.................... 97-102

pollution by ................. 23-48

$\mathrm{Pu}$, sulphite, indestructibility of ...... 50-51 manufacture of, processes of .......... 49-50

wastes of ....................... 50-51

benefits from ................ 52

dilution of ................... 65

effect on Ausable River from... 51-52 effect on Lake Champlain from. 58-65 pollution by............ 49-52, 64-65

Quaker Smith Reef, water near, analysis of. 20

Rangeley Lakes, Me., water of, solids in... 20

Richelieu River, location and character of. 18

Rockwell City, Iowa, water at, analysis of. $\quad 38$

Rogers, James, acknowledgments to...... $\quad 10$

Rogers, J. \& J. Co., mills of, location of .... 49

mills of, manufacture of sulphite pulpat $49-51$

wastes of ..................... 50-51

effects of.................... 51-65

effects of, summary of......... 115

Sabin, A. H., analyses by .............. 69,81

Sand bars, direction of ................. $\quad 19$

San Diego, Cal., water at, analysis of ...... 38

Saranac River, valley of, character of..... 15

Sawdust, accumulations of.............. 115 
Sawdust, accumulations of, view of........ 48

Saxicava rugosa, occurrence of ........... 14

Scalaria groenlandica, occurrence of....... 14

Schuyler Island, water near, solids in..... 63

Sedimentation bed, benefits from ......... 97

character and use of $\ldots . . . \ldots \ldots \ldots \ldots . .33$

criticism of ......................... $47-48$

effluent from, analysis of ............. 31

efficiency of ................... 35-36, 96-97

fioods on ......................... $35-36$

Sedgwick, W. T., investigations and report

by $\ldots \ldots \ldots \ldots \ldots \ldots \ldots \ldots \ldots 6.68-74,89$

Seeley, H. M., analyses by ............. 69,80

Seward, W. H., report to ................ 14

Sewage, effects of, conclusions concerning. $\quad 116$ effect of mill wastes on............ 112-113

pollution from .................... 66-90

Sioux Falls, S. Dak., water at, analysis of . . $\quad 38$

Soda, caustic, recovery of ................ 28 use of........................... 25,29

Soda-mill waste. See Pulp, soda, wastes of.

Sodium chloride, occurrence of ........... 108

Spirogyra, effect of mill wastes on....... 110-111

Split Rock, water near, analysis of........ 20

Spruce, use of $. . . \ldots \ldots \ldots \ldots \ldots \ldots \ldots \ldots . \quad 49$

Stearns, F. P., on Burlington water supply. $\quad 70$

Stone, B. H., acknowledgments to........ 10 on Bacillus coli communis ............ 82

Sulphite-pulp waste. (See Pulp, sulphite, wastes of.)

Sulphur, use of ........................ 49

Tellina groenlandica, occurrence of....... 14

Terebratula psittacea, occurrence of ....... 14

Ticonderoga, N. Y., sewage of ........ 91, 93-94 view at ............................. 90

Ticonderoga Creek, character of .......... 93 effect of soda-mill wastes on ......... 97-102 fish in ........................... 115

investigations at mouth of ......... 97-107 conclusions concerning ......... 107-108 maps showing ................ 101, 105 lime in

soda in ........................... 95-96

water of, analysis of ...........93-94,98, 100 comparison of lake water and..... 99-100
Ticonderoga Pulp and Paper Co., mills of,

location of................... 94,97

mills of, manufacture at, processes of .. 90-91 view of $\ldots \ldots \ldots \ldots \ldots \ldots \ldots \ldots . .96$ sedimentation bed of, view of...... 92 wastes of, effects of......... 90,94,97-108 effects of, conclusions concern-

ing $\ldots \ldots \ldots \ldots \ldots \ldots \ldots, 107-108,116$ water power of, view of .......... 90

Topeka, Kans., water at, analysis of ....... $\quad 38$

Trembleau Point, location of ............ 18

Tritonium anglicum, occurrence of....... 14

fornicatum, occurrence of........... 14

Typhoid bacillus, effect of mill wastes on . 111,

$113-114$

Typhoid fever, occurrence of........ $69-71,74,89$

Ulothrix, effect of mill wastes on ......... 110

Water of lake, analyses of ................ $\quad 20$

character of ....................... 19-21

Water used in soda-pulp manufacture, amount of ................... 25

Water supplies, public, analyses of......... 38

Water supply, function of lake as......... 13-14

Waterloo, Iowa, water at, analysis of ...... $\quad 38$

West Milwaukee, Wis, water at, analysis of. $\quad 38$

Whitehall, N. Y., sewage from ........... 91

Willsboro, N. Y., view at................. 22

Willsboro Bay, character of .............. 18

water at, analysis of ................. 20

Winnepesaukee Lake, N. H., water of, solids in......................... 20

Winchester, Va., water at, analysis of..... $\quad 38$ Winooski, N. Y., sewage of............ 66,85-86

Winooski River, character of.............. 66 pollution of........................ 66,85 sewage from, effects of ............... 85-88

summary concerning............ 115

Winslow, C.-E. A., samples sent to ........ 111

Witthaus, R. A., analyses by ...........69,81

Wood, extractives of, character of......... 24

Wood, ground, accumulations of ......... $\quad 115$ accumulations of, view of ............ 48

Wood Creek, location of................. $\quad 16$

Yuma, Ariz., water at, analysis of.......... 38 


\title{
PUBLICATIONS OF UNITED STATES GEOLOGICAI SURVEY.
}

\author{
[Water-supply and Irrigation Paper No. 121.]
}

The publications of the United States Geological Survey consist of (1) Annual Reports; (2) Monographs; (3) Professional Papers; (4) Bulletins; (5) Mineral Resources; (6) Water-Supply and Irrigation Papers; (7) Topographic Atlas of the United States, folios and separate sheets thereof; (8) Geologic Atlas of the United States, folios thereof. The elasses numbered 2, 7, and 8 are sold at cost of publication; the others are distributed free. A circular giving complete lists may be had on application.

The Professional Papers, Bulletins, and Water-Supply Papers treat of a variety of subjects, and the total number issued is large. They have therefore been classified into the following series: A, Economic geology; B, Descriptive geology; C, Systematic geology and paleontology; D, Petrography and mineralogy; E, Chemistry and physies: F, Geography; G, Miscellaneous; H, Forestry; I, Irrigation; J, Water storage; K, Pumping water; L, Quality of water; M, General hydrographic investigations; N, Water power; O, Underground waters; P, Hydrographic progress reports.

The following Water-Supply Papers are out of stock, and can no longer be supplied: Nos. 1-16, 19, $20,22,29-34,36,39,40,43,46,57-65,75$. Complete lists of papers relating to water supply and allied subjects follow. ( $P P=$ Professional Paper; $B=$ Bulletin; WS=Water-Supply Paper.)

\section{Series L-QUality of Water.}

WS 3. Sewage irrigation, by G. W. Rafter. 1897.100 pp., 4 pls.

WS 22. Sewage irrigation, Pt. II, by G. W. Rafter. 1899.100 pp., 7 pls.

WS 72. Sewage pollution near New York City, by M. O. Leighton. 1902.75 pp., 8 pls.

WS 76. Flow of rivers near New York City, by H. A. Pressey. 1903.108 pp, 13 pls.

WS 79. Normal and polluted waters in northeastern United States, by M. O. Leighton. $1903.192 \mathrm{pp}$., $15 \mathrm{pls}$.

WS 108. Review of the laws forbidding pollution of inland waters in the United States, by E. B. Goodell. 1904. $120 \mathrm{pp}$.

WS 108. Quality of water in the Susquehanna River drainage basin, by M. O. Leighton, with an introductory chapter on physiographic features, by G B. Hollister. 1904.76 pp., 4 pls.

WS 113. Strawboard and oil wastes, by R. L. Sackett and Isaiah Bowman. 1905.52 pp., 4 pls.

WS 121. Preliminary report on the pollution of Lake Champlain, by M. O. Leighton. 1905.119 pp., 13 pls.

Correspondence should be addressed to

The Director,

United States Geological Survey,

Washington, D. C. 


\section{LIBRARY CATALOGUE SLIPS.}

[Mount each slip upon a separate card, placing the subject at the top of the second slip. The name of the series should not be repeated on the series card, but the additional numbers should be added, as received, to the first entry.]

\section{Leighton, Marshall Ora, I874-}

... Preliminary report on the pollution of Lake Champlain, by Marshall Ora Leighton. Washington, Gov't print. off., I905.

119, iii p. illus., XIII pl. (incl. map). $23^{\mathrm{cm}}$. (U. S. Geological survey. Water-supply and irrigation paper no. 121.)

Subject series: L, Quality of water, 9.

1. Water, Pollution of. 2. Lake Champlain.

\section{Leighton, Marshall Ora, 1874-}

... Preliminary report on the pollution of Lake Champlain, by Marshall Ora Leighton. Washington, Gov't print. off., I905.

119, iii p. illus., XIII pl. (incl. map). 23 $3^{\mathrm{cm}}$. (U. S. Geological survey. Water-supply and irrigation paper no. 121.)

Subject series: L, Quality of water, 9.

1. Water, Pollution of. 2. Lake Champlain.

U. S. Geological survey.

Water-supply and irrigation papers.

no. I2I. Leighton, M. O. Preliminary report on the pollution of Lake Champlain. I905.

U. S. Dept. of the Interio
see also
U. S. Geological survey. 